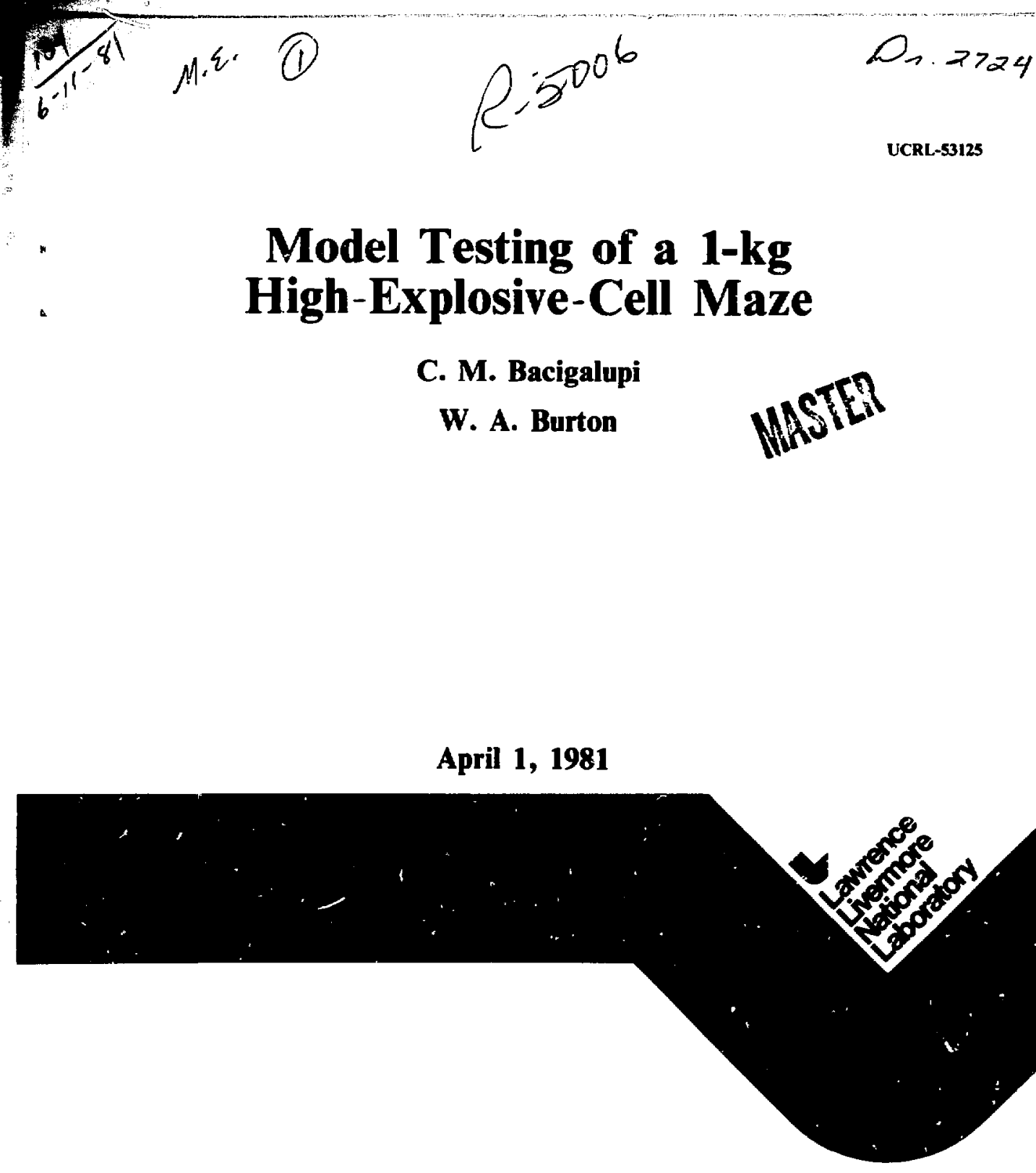

April 1, 1981 


\title{
Model Testing of a 1-kg High-Explosive-Cell Maze
}

\author{
C. M Bacizalupi
}

W. A. Bartom

Manuscript date: April 1, 1981

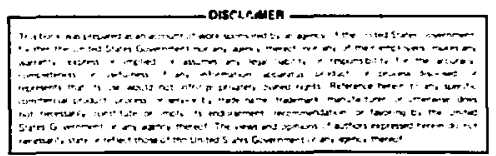

\section{LAWRENCE LIVERMORE LABORATORY} University of California • Livermore, Califonia $\bullet 94550$ 


\section{CONTENTS}

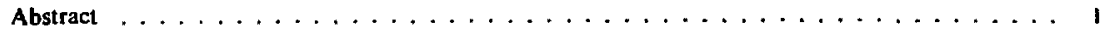

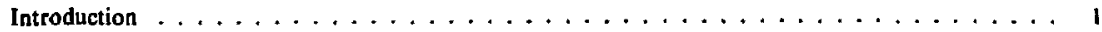

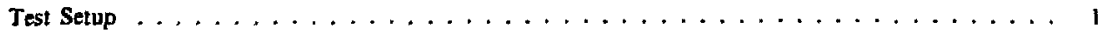

Cell Models . . . . . . . . . . . . . . . . . . . . . . . .

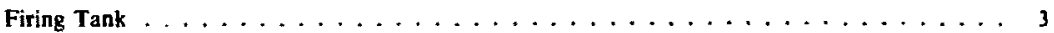

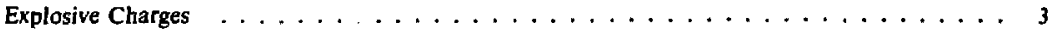

Instrumentation $\ldots \ldots \ldots \ldots \ldots \ldots \ldots \ldots \ldots$

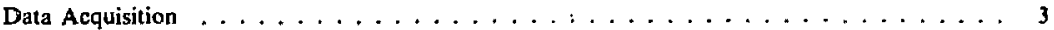

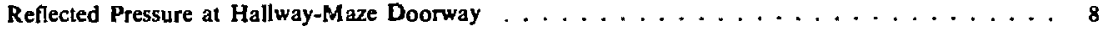

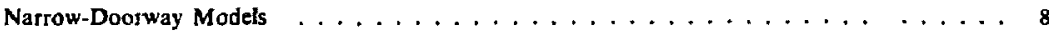

One-Eighth-Scale Scries $\ldots \ldots \ldots \ldots \ldots \ldots$

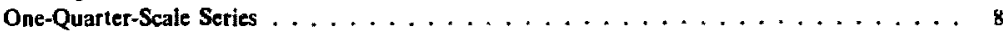

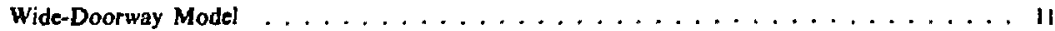

One-Eighth-Scale Series $\ldots \ldots \ldots \ldots \ldots \ldots \ldots \ldots$

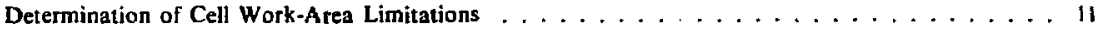

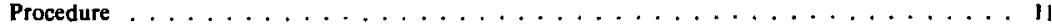

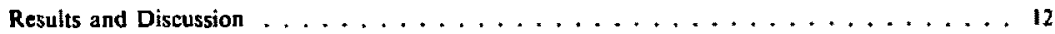

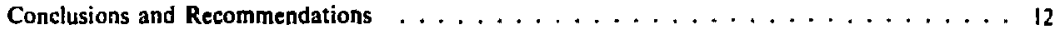

Effects of Blast Walls and Baffles: Narrow-Door Model $\ldots \ldots \ldots \ldots \ldots$

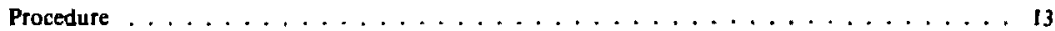

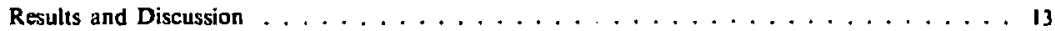

Summary and Conciusions ......................... 14

Hallway Pressure Profile $\ldots \ldots \ldots \ldots \ldots \ldots \ldots \ldots \ldots$

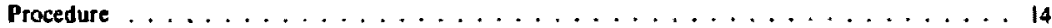

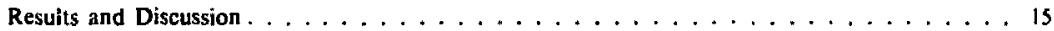

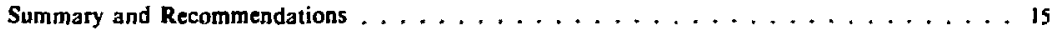

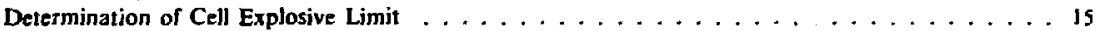

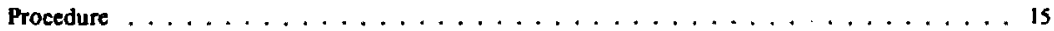

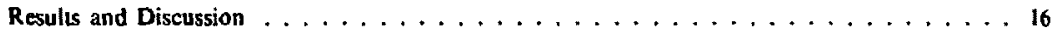

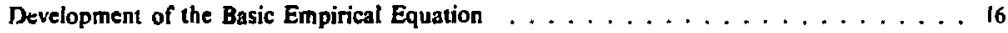

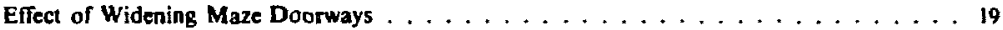

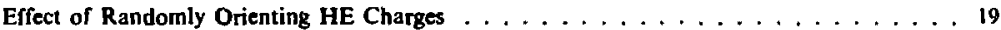

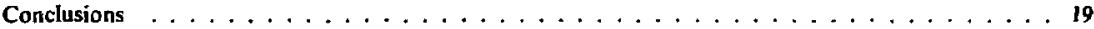

Proof of Scaling $\ldots \ldots \ldots \ldots \ldots \ldots \ldots$

Cell Work-Area Limitations . . . . . . . . . . . . . . . . . . . 20

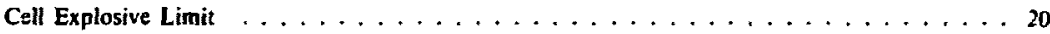

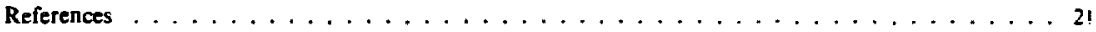

Appendixes

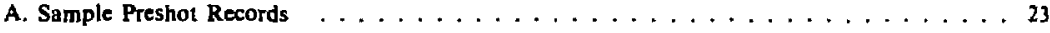

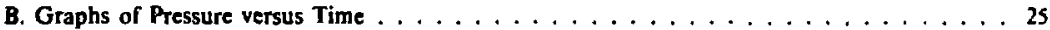




\section{Model Testing of a 1-kg \\ High-Explosive-Cell Maze}

\section{ABSTRACT}

The basement of the proposed High Explosives Applications Facility (Building 353) at the Lawrence Livermore National Laboratory includes several explosive test cells for the assembly and/or storage of up to $10 \mathrm{~kg}$ of high explosive (HE). This document reports 1/8-scale and 1/4-scale model tests conducted to confirm maze design criteria, to determine the cell explosive weight limit based on an allowable $10 \mathrm{psi}$ reflected shock pressure at the hallway-maze doorway, and to specify permissible areas for handling HE within the cell. The integrity of cube-root scaling of the explosive charges detonated in the 1/8-scale model was verified by explosive testing in a comparable 1/4-scale model. Reflected shock pressures in the hallway adjacent to the maze and the effect of HE charge orientation were investigated and are also reported.

\section{INTRODUCTION}

The Lawrence Livermore National Laboratory (LLNL) has been funded by the Department of Energy (DOE) through the DOE San Francisco Operations Office (SAN) to design a High Explosives Applications Facility (HEAF) to conduct high explosives reseurch at the Livermore site.

The purpose of this model testing was to obtain the information necessary (l) to confirm basic design criteria for the maze of a $12-\mathrm{ft}-5 q$ by $12.5-\mathrm{ft}$ high reinforced concrete cell that would structurally sustain an accidental 10-kg HE explosion: (2) to determine the cell explosive weight limit: and (3) to specify permissible HE handling areas within the cell. All these design criteria are based on the specified maximum allowable reflected shock pressure of 10 psi at the cell hallway-maze doorway.
Both 1/8-scale and 1/4-scale models of the proposed 1-kg cell were designed and constructed with the equivalent of 2-ft-4-in. by 6-ft-8-in. doorways. Doorways on a later $1 / 8$-scale model were widened from 3.5 to 4.0 in. (2-ft-8-in. full scale) in compliance with a subsequently imposed National Fire Protecion Association requirement. The effects of increasing doorway width and of random charge orientation are discussed. The 18-in.-sq by 18.75-in.-high 1/8-scale model was built of 'welded/bolted aluminum plate, and the 36-in.-sq by 37.5-in.-high 1/4-scale model was of welded steel pl:ıte. All test firings were conducted inside a steel 350-g firing tank in Buil ing 345 at LLNL.

\section{TE:T SETUP}

\section{CELL MODELS}

The cell models, which included the muzes and adjacent hallways, were 1/8-scale and 1/4-scale duplicates of the proposed explosive test cell. All dimensions below are inside dimensions unless otherwise indicated.
The 1/8-scale model was weld/bolt assembled from 0.5 -in. aluminum plate. The cell section was 's-in. square, the maze 4.5 -in. wide by 18 -in. long, and the hallway 12 -in. wide by 13 -in. long. Figure 1 shows the 2-in.-thick walls of the maze. Doorways, initially 10-in. high by 3.5 -in. wide, were later widened ta $4 \mathrm{in.}$ to model an increase of cell door 


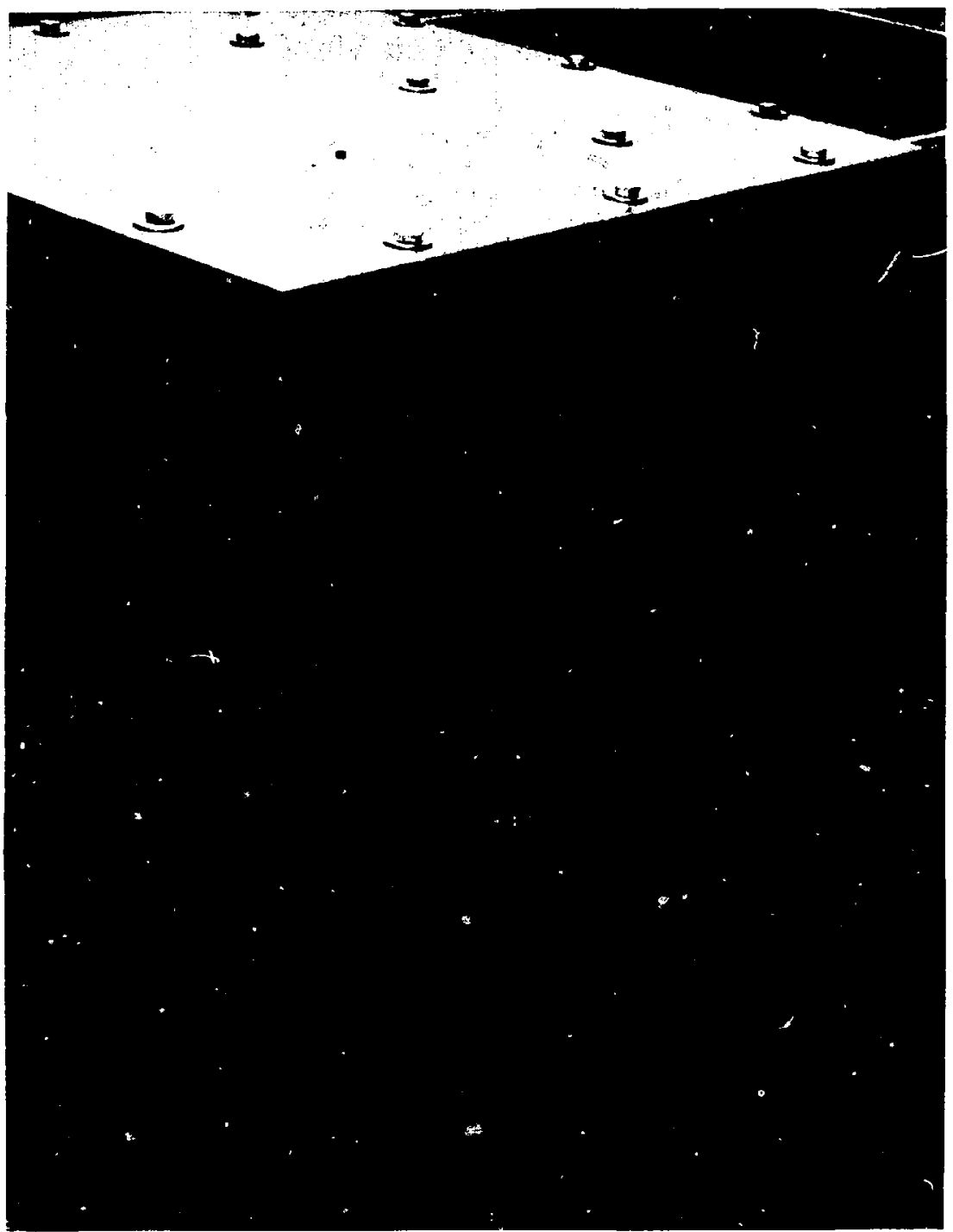

FIG. 1. One-eighth-scale model showing hallway-maze doorway (cell ceiling plate removed). 
width from $2 \mathrm{ft} 4 \mathrm{in}$. to $2 \mathrm{ft} 8 \mathrm{in}$. The inside ceiling height of the entire model was 18.75 in. Figure 2 is the bisic cell/maze layout of this model.

The 1/4-scale model was weld-assembled from $3 / 8$-in. steel plate. The cell section was 36 -in. sq, the maze 9-in. wide by 36 -in. long, and the hallway 24 in. wide by 36 -in. long. The 4 -in.-thick maze walls were filled with concrete. Figure 3 shows the 7-in.wide by 20 -in.-high doorways. The inside ceiling height of the entire model was $37.5 \mathrm{in}$. The flat walls and ceiling of the cell section were stiffened by welding 2 by 6 steel channels to the outside surface.

\section{FIRING TANK}

All model testing was conducted inside a steel firing tank in Building 345. The firing tank, which is rated to safely contain an explosive charge of up to $350 \mathrm{~g}$, is 8-ft diam by 8-ft long and is closed by a hydraulically rotated locking ring on an approximately 6-ft-diam forged steel door.

\section{EXPLOSIVE CHARGES}

Each HE charge consisted of a cylindrical pellet of PBX 9407 pressed to a density of $\pi .6 \mathrm{~g} / \mathrm{cm}^{3}$. to which was glued an MC 1957A detonator cen. tered on the end of the pellet by a 0.0625-in.-thick Lucile washer. After the preassembled detonator/washer was glued to the pellet with Eastman 910. Hysol 615 Epoxy Patch was applied to support the detonator-washer bond. Charges for $1 / 8$-scale testing were of $12.64-\mathrm{mm}$ (approximately 0.5 -in,) diam and weighed $1000 \mathrm{~g} / 8^{3}$ or $1.953 \mathrm{~g}$, in. cluding the detonator weigit of $0.021 \mathrm{~g}$; nominal pellet weight was $1.932 \mathrm{~g}$. Charges for $1 / 4$-acale testing were of $25.34 \mathrm{~mm}$ (approximately 1.0-in.) diam and weighed $1000 \mathrm{~g} / 4^{3}$ or $15.625 \mathrm{~g}$, including the detonator weight; nominal pellet weight was $15.604 \mathrm{~g}$.

Unless otherwise not od, explosive charges were oriented with their cylindrical axes perpendicular to the plane of the cell-maze doorway (N-S) and the detonator was glued to the maze doorway end of the pellet.

\section{INSTRUMENTATION}

Reflected pressures were sensed by mode] XTM-1-190-50 Kulite pressure transducers having a calibrated pressure range of $50 \mathrm{psi}$ and a maximum rated pressure of $100 \mathrm{psi}$. The transducer used to sense pressures at the maze doorways was threaded into a 0.750 -in.-diam by 0.875 -in.-long cylindrical aluminum adapter. The 0.156 -in.-diam face of the transducer diaphragm was flush with the end of the cylinder. Although this approximately 5:1 diameter ratio is sufficient for reliable sensing of shock pressures, it is inappropriate for accurately detecting impulse. A laboratory clamp assembly, isolated from the model (and from the firing tank) by a rubber pad under its base, was used to center the transducer face in the hallway plane of the maze doorway (see Fig. 4). The transducer used to sense pressures along the hallway centerline was mounted in a 2.750-in.-diam sharp-edged tapered disk that assured reliable sensing of reflected shock pressures, free air pressures, and impulse. This transkucer assembly was similarly mounted in a shock-isclated laboratory clamp assembly (see Fig. 5, which also shows another transducer that was used ta obtain pressure readings for structurail ciesign).

Amplified millivolt pressure signals from each transducer were sampled every $0.01 \mathrm{~ms}$ by individual Biomation data receivers during the 20-ms recording period. A Tektronics computer display terminal in the control soom was used to direct all data processing. Pressure-time information from the data receivers was processed by a Modular Computer System model 11/221. displayed on the terminal screen, printed out on a Versutek Matrix printer-plotter, and stored on magnetic tape for subsequent data analysis and future reference.

\section{DATA ACQUISITION}

The data was stored on magnetic tape by the computer. A Tektronics computer display terminal in the computer room was used to reprint the original graphs, to print new graphs of selectively filtered data, and to obtain integrated impulses, as required for data analysis. 


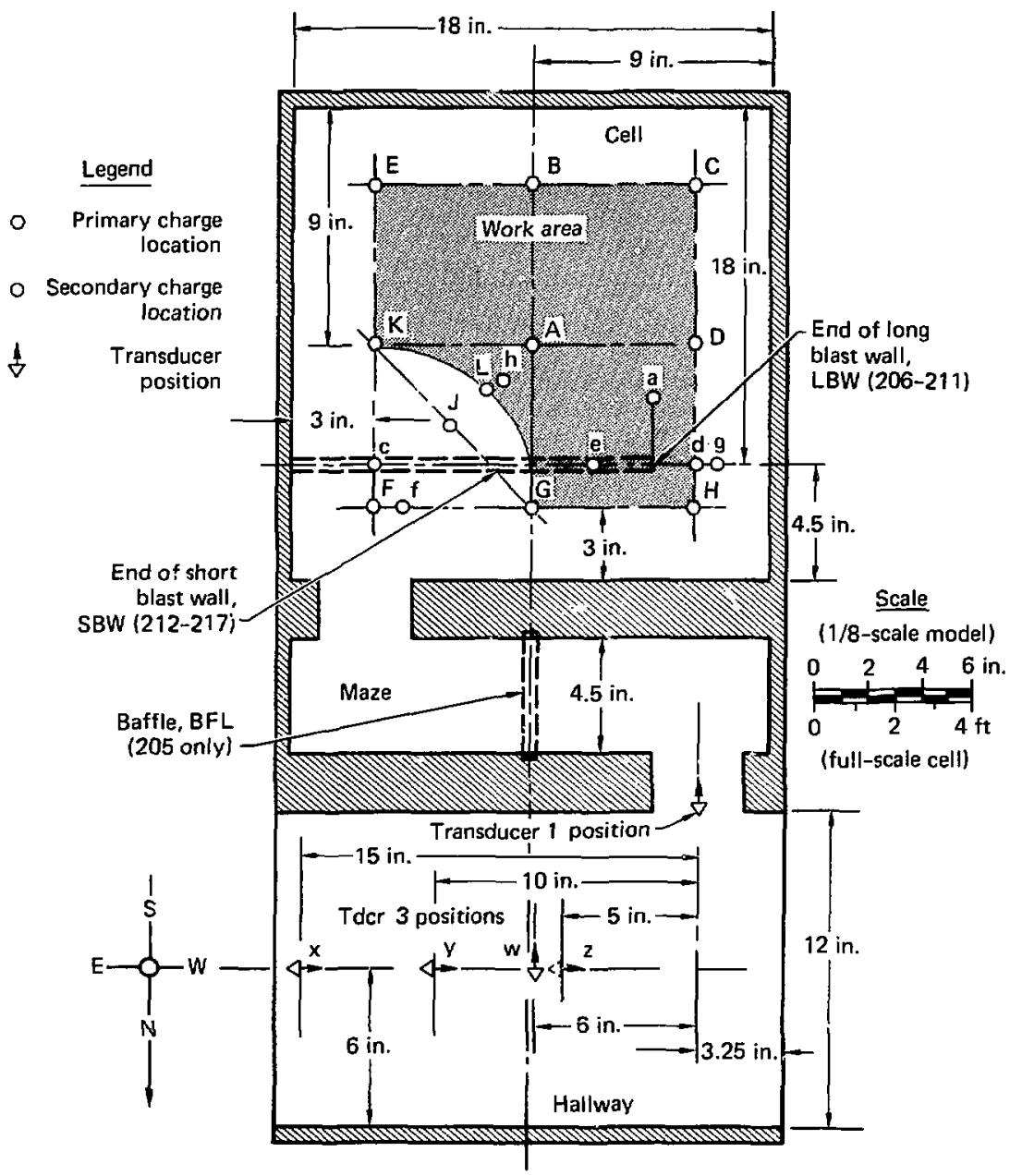

FIG. 2. Basic cell-maze layout, 1/8-scale shown. 


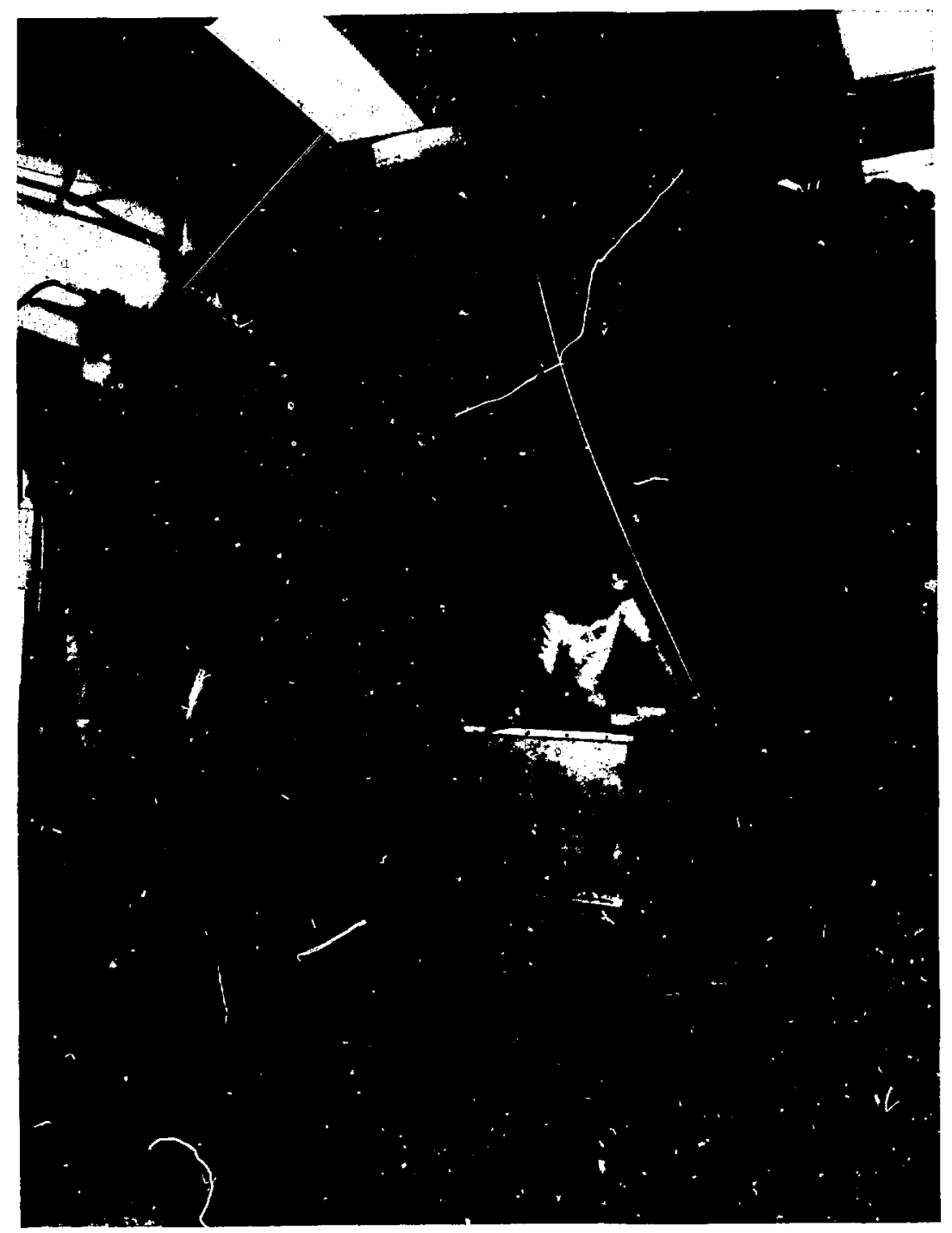

FIG. 3. Firing tank in Building 345 at LLNL, Livermore, California. 


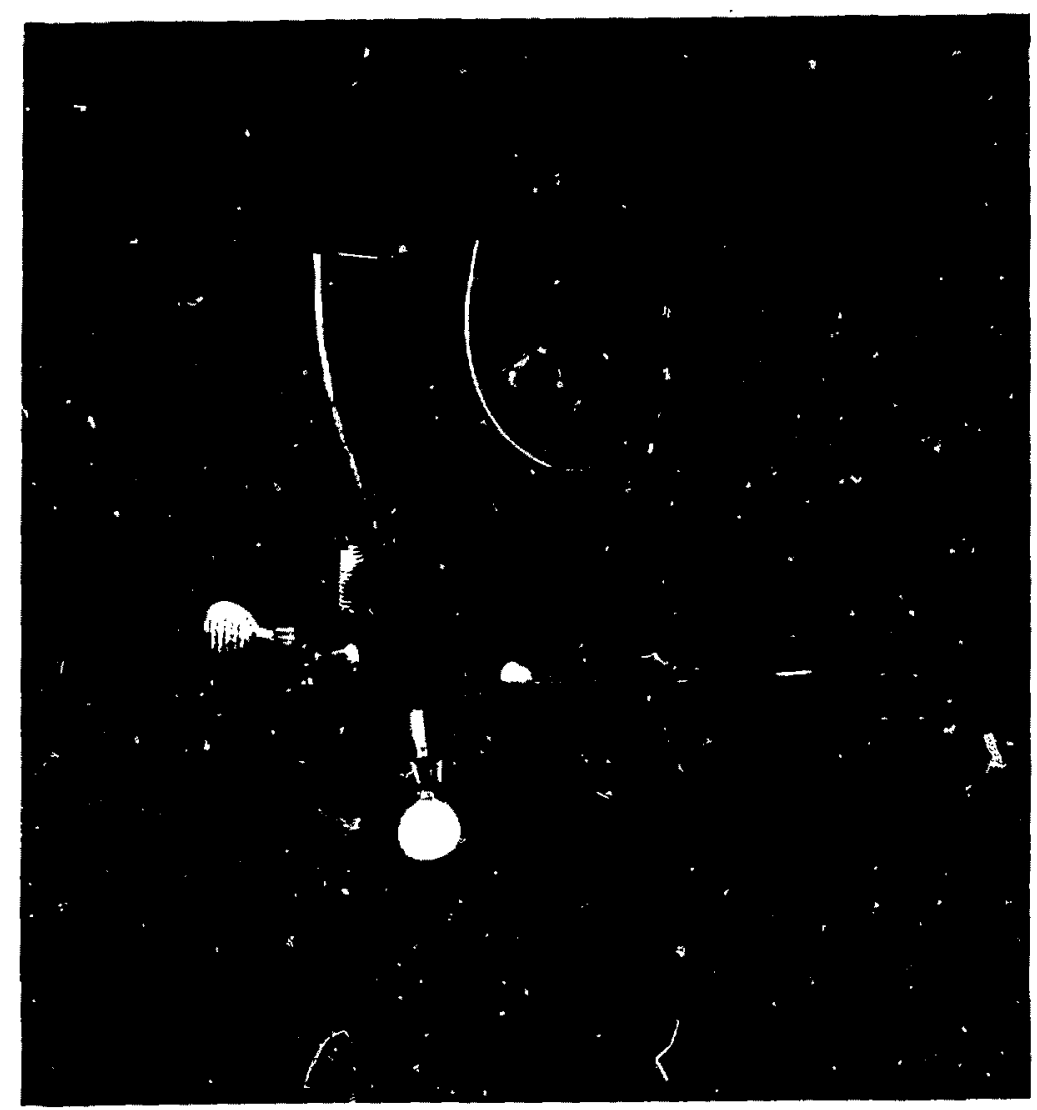

FIG. 4. Transducer stand (foreground) for hallway pressure sensing. 


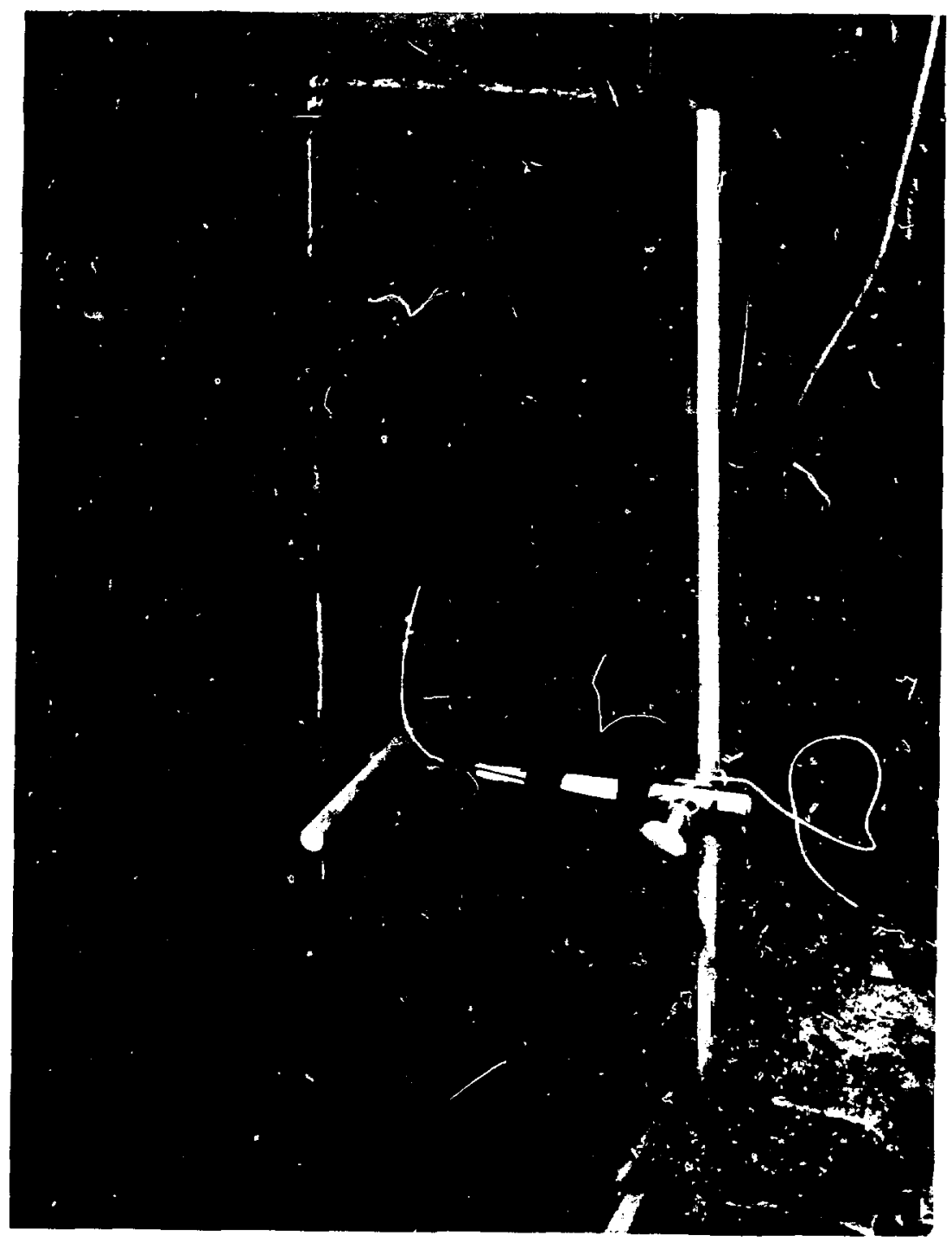

FIG. S. Hallway-maze doorway of 1/4-scale model showing centered transducer. 


\section{REFLECTED PRESSURE AT HALJWAY-MAZE DOORWAY}

\section{NARROW DOORWAY MODELS}

\section{One-Eighth-Scale Series}

Procedure. The 1/8-scale model with 3.5 -in. by 10.0-in. doorways (Fig. 6) was placed in the firing tank and the transducers were installed at the appropriate locations. The cell ceiling panel (with the HE charge) was bolted in place an 1 the detonator cable was connected. The tank door was then closed and secured and the explosive charge was detonated from the adjacent control room.

Results and Discussion. The peak pressures sensed by the transducer at the maze doorway in position 1 (see Fig. 2) and the times after detonation at which the peak pressures were recorded and are listed in Table 1. The average peak pressure for the four detonations at $\mathrm{K}$ was $14.0 \mathrm{psi}$ at the averase arrival time of $2.9 \mathrm{~ms}$ after detonation. Pressureversus-time graphs for these experiments (258 through 261) art in sippendix B.

The standard deviation of the peak pressures for experiments 258 through 261 is $\pm 0.6 \mathrm{psi}$. All pressure data falls within the range of 1.3 standard deviations from the average. The most probable error of the average peak pressure, as calculated by Bessel's formulas, ${ }^{1}$ is \pm 0.2 psi. The standard deviation of the time of arrival of the peak pressure for experiments 258 through 261 is \pm 0.1 r.s. All time data fall within the range of 2.0 atandard deviations from the average. The most probable encor of the average time is $\pm 0.0 \mathrm{~ms}$.

Conclusions and Recommendations. The recorded data appeared to be sufficiently consistent for comparison with the results of subsequen: 1/4scale testing, to determine preliminary cell explosive limits, and to prove scaling.

\section{One-Quarter-Scale Series}

Procedure. The test procedure was identical to that for the 1/8-scale series, except that the HE charge was positioned (at K) through a flanged hole in the center of the cell ceiling instead of being attached to the removable ceiling plate. Figure 7 is the narrow doorway 1/4-scale model used for this series.

Results and Discussion. The peak pressures sensed by transducer 1 (hallway-maze doorway) and the times at which they were recorded are listed in Table 2. The average peak pressure for the three shots at location $K$ was 14.0 psi at the average time of $5.9 \mathrm{~ms}$ after detonation. Several high, singlepressure peaks and one very narrow high peak conıplicated rational analysis of the computer-plotted graphs of experiments 225 and 229. Their source was reasonably attributed to projected Lucite particles from the unavoidably shattered HE charge holder striking the exposed diaphragm of th: pressure transducer at the precise time when a signal was being transmitted to the Biomation data receiver. Considering the extremely low impulse represented by these spurious pressure escalations occurring at typically lower-impulse times, they were disregarded as inappropriate for comparative data analysis. Pressure-versus-time graphs for these experiments are included in Appendix A.

TABLE 1. One-eighth-scale experiments si locstion $K$ south, narrow doorway.

\begin{tabular}{cccc}
\hline $\begin{array}{c}\text { Experiment } \\
\text { number }\end{array}$ & $\begin{array}{c}\text { Peak reflected } \\
\text { pressure at } \\
\text { prosition } 1 \text { (psi) }\end{array}$ & $\begin{array}{c}\text { Time after } \\
\text { detonation } \\
(\mathrm{ms})\end{array}$ & $\begin{array}{c}\text { Weight of HE } \\
\text { charge, including } \\
\text { detonator (g) }\end{array}$ \\
\hline 258 & 13.7 & 2.8 & 1.948 \\
259 & 14.5 & 3.0 & 1.948 \\
260 & 14.7 & 3.0 & 1.953 \\
261 & 13.2 & $\frac{2.9}{2.9}$ & $\frac{1.950}{1.950}$ \\
Avernge: & 14.0 & & \\
\hline
\end{tabular}




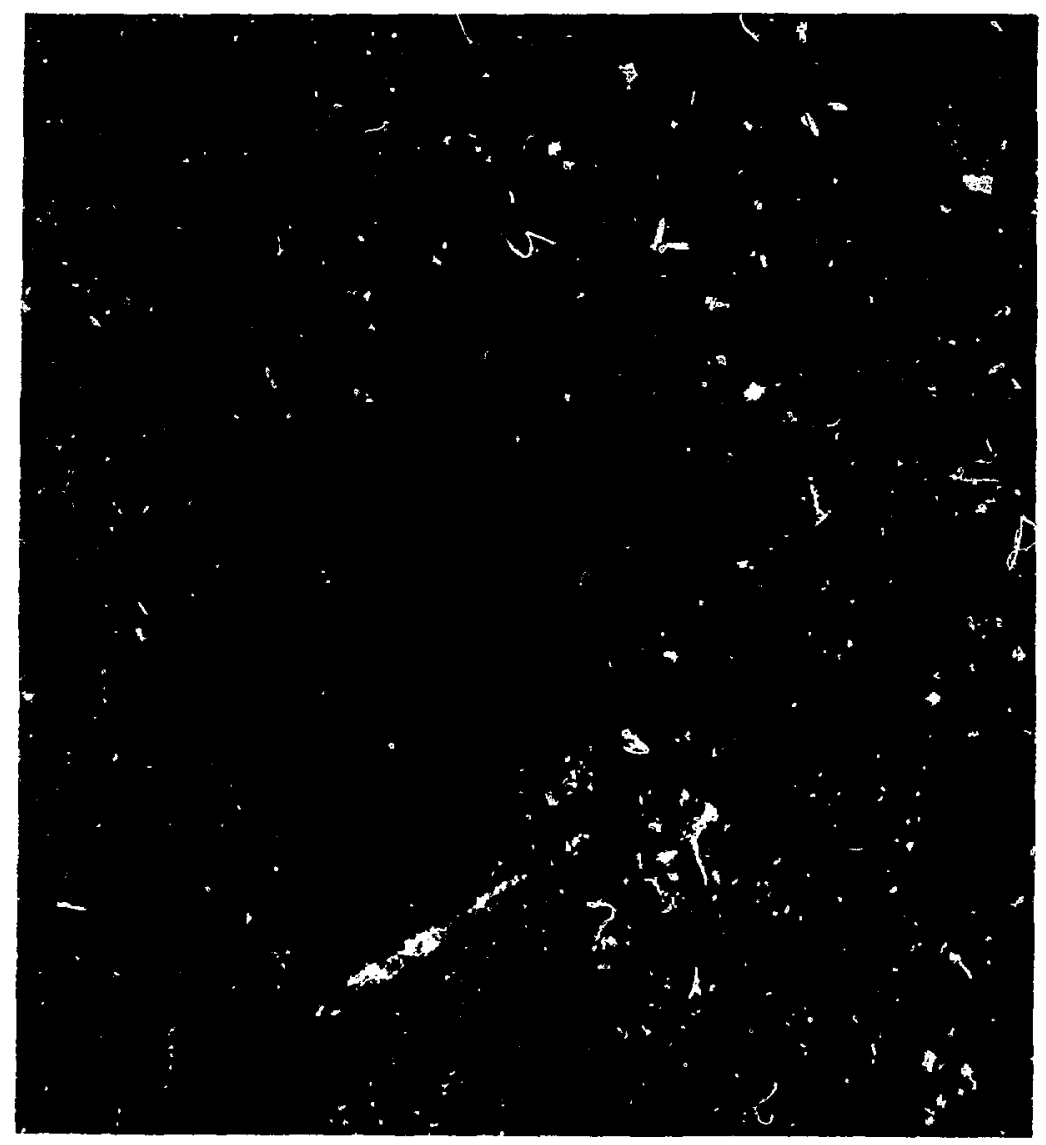

FIG. 6. One-eighth-scale model with cell ceiling plate removed. 


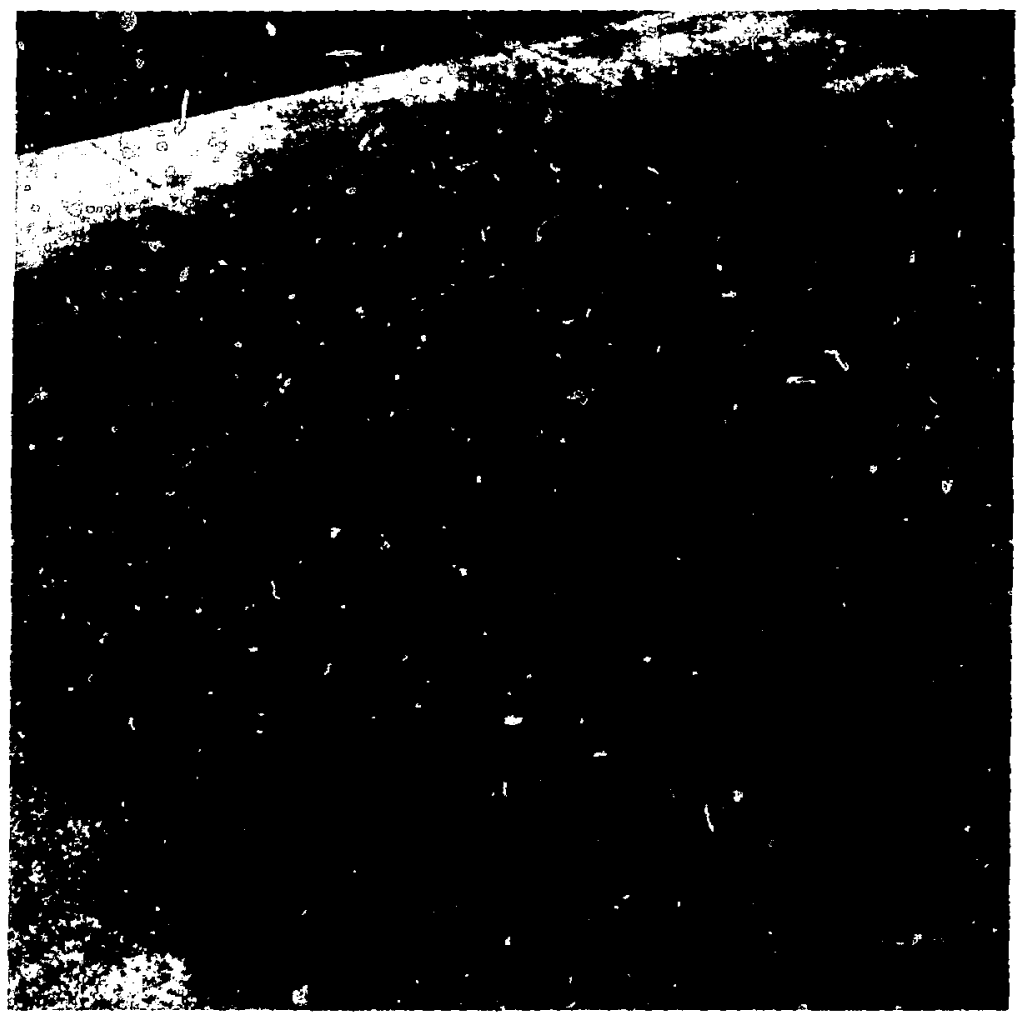

FIG. 7. Ome-quarter-scale model.

TABLE 2. One-quarter-scale experiments at locatiog $K$ soth, narrow doorway.

\begin{tabular}{|c|c|c|c|c|}
\hline $\begin{array}{l}\text { Experiment } \\
\text { mumber }\end{array}$ & $\begin{array}{l}\text { Presure at } \\
\text { irasumencer } \\
\text { position I } \\
\text { (psi) }\end{array}$ & $\begin{array}{l}\text { Tine afier } \\
\text { detometion } \\
\text { shock (ms) }\end{array}$ & 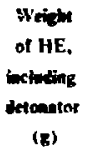 & $\begin{array}{l}\text { Remarks } \\
\text { (SP }=\text { single pratk: } \\
\mathbf{N P}=\text { marrow peals) }\end{array}$ \\
\hline 225 & 12.9 & 5.9 & $: 5.654$ & $\begin{array}{l}\text { SP to } 15.1 \mathrm{psi} \text { at } 2.6 \mathrm{~ms} \text { ind } \\
\mathrm{NP} \text { to } 16.3 \mathrm{psi} \text { at } 4.9 \mathrm{~ms}\end{array}$ \\
\hline 228 & 14.3 & 5,9 & 15.044 & \\
\hline 229 & 14.7 & 60 & 15.644 & SP so 15.7 औt 5.6 as \\
\hline A vernge: & 14.0 & $\overrightarrow{5.9}$ & 15,647 & \\
\hline
\end{tabular}




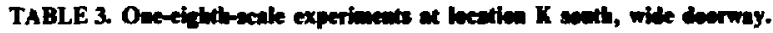

\begin{tabular}{|c|c|c|c|}
\hline $\begin{array}{l}\text { Expetioneat } \\
\text { numer }\end{array}$ & $\begin{array}{l}\text { Pealk reficald } \\
\text { prenome (pai) }\end{array}$ & 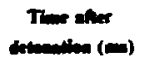 & $\begin{array}{l}\text { Expleative } \\
\text { moline (8) }\end{array}$ \\
\hline 276 & 13.6 & 26 & 15 \\
\hline $2 \pi$ & 16.3 & 26 & 1.534 \\
\hline 278 & IS.6 & 26 & 1.502 \\
\hline 282 & 13.6 & 27 & I.sss \\
\hline 283 & 143 & 2.6 & 2.946 \\
\hline 207 & 143 & 23 & 1.953 \\
\hline Avernge: & 147 & 27 & 1.98 \\
\hline
\end{tabular}

The standard deviation of the peak reflected pressures for experiments 225,228 , and 229 is \pm 0.8 psi. All pressure data fall within the range of 1.4 standart deviations from the average. The most probable error of the average peak pressure, as calculated by Bessel's formulas, ${ }^{1}$ is \pm 0.4 psi. The standard deviation of th. time of arrival of the peak pressure for these experiments is \pm 0.0 ms. The most probable error of the average time is $\pm 0.0 \mathrm{~ms}$.

Conslusions and Recommendations. The recorded data appeared to be sufficiently consistent for comparison with the results of experiments in the narrow doorway, 1/8-scale model, to prove sealing, and to confirm the peak reflected pressure that is credible at the hallway-maze doorway of a fullscale test cell with narrow doorways.

\section{WIDE DOORWAY MODEL}

\section{One-Eighth-Scale Series}

Procedure. The 1/8-scale model, with maze doorways widened from 3.5 to $4.0 \mathrm{in}$. was placed in the firing tank, the cell ceiling panel (with the HE charge located at position K) was bolted in place. and the detonator cable was connected. The tank door was then closed and secured and the explosive charge was detonated from the adjacent control room.

Rewits and Discrion. The peak reflected pressures sensed by the transducer positioned at the hallway-maze doorway, and the times after detonation at which the pressures occurred, are listed in Table 3. The average peak pressure for the six south-oriented detonations at $K$ was $14.7 \mathrm{psi}$ with an average arrival time of $2.7 \mathrm{~ms}$ after detonation. Pressure-versus-time graphs for these experiments (276-278, 282, 283, and 287) are included in Appendix $\mathbf{A}$.

The standard deviation of the peak pressures for these experiments is \pm 1.0 psi. All pressure data fall within the range of 1.6 standard deviations from the average. The most probable error of the average peak pressure, as calculated by Bessel's formulas, 'is \pm 0.3 psi. The standard deviation of the time after detonation for these experiments is $\pm 0.1 \mathrm{~ms}$. All time data fall within the range of 1.0 standard deviations from the average. The most probable error of tive average time is $\pm 0.0 \mathrm{~ms}$.

Couchusions and Recompenations. The resorded data appeared to be sufficiently consistent for comparison with the results of experiments conducted in the narrow doorway models to determine final cell explosive limits.

\section{DETERMINATION OF CELL WORK-AREA LIMITATIONS}

\section{PROCEDURE}

The only change in the test procedure was positioning of the explosive charge at locations other than $\mathbf{K}$. Unless otherwise noted, all charges were oriented toward the south and the pressures were monitored at the hallway-maze doorway. See Fig. 2 for locations of HE charges and the position of Iransducer 1. 
TABLE 4. Experiments at lecatiens ofier than $K$.

\begin{tabular}{|c|c|c|c|c|c|}
\hline $\begin{array}{l}\text { Modet } \\
\text { scale }\end{array}$ & $\underset{\text { Exporiver }}{\text { (location) }}$ & $\begin{array}{l}\text { Reflested } \\
\text { prssure ar } \\
\text { panition } 1 \\
\text { (pai) }\end{array}$ & 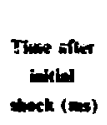 & $\begin{array}{l}\text { Wetede of HE. } \\
\text { (e) }\end{array}$ & 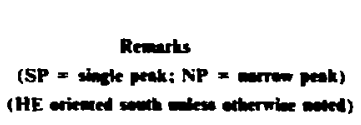 \\
\hline \multicolumn{6}{|c|}{ Nientor downey } \\
\hline $1 / 8$ & 214(A) & 11.1 & $3.4=1.5$ & 1.953 & SP to lis.3 psi tate al ch as \\
\hline $1 / 8$ & 22mG) & 13.3 & 3.0 & 1.953 & \\
\hline $1 / 9$ & $\operatorname{mil}(\mathbf{J})$ & 12.3 & 3.0 & 1.953 & $\begin{array}{l}\text { SP to } 12.5 \text { pi at } 2.6 \text { as and } \\
\text { peak to I6.0 pai lote at } 4.1 \mathrm{~ms}\end{array}$ \\
\hline $1 / 4$ & $22(G)$ & 13.3 & 6.2 & 15460 & \\
\hline $1 / 4$ & $227(G)$ & 13.6 & 5.9 & 15.648 & NP to It.e pai at $7.2 \mathrm{~ms}$ (lece) \\
\hline $1 / 4$ & $234(E)$ & 11.2 & 6.7 & 15.69 & Peal of 13.5 mi late 919.8 ms \\
\hline $1 / 4$ & $231(C)$ & 11.9 & 7.3 & $\$ 5.652$ & \\
\hline \multicolumn{6}{|c|}{ Wide doormay } \\
\hline $1 / 8$ & $303(D)$ & 11.8 & 3.7 & I.951 & \\
\hline $1 / 8$ & 304(t) & 145 & 4.5 & 1.952 & \\
\hline $1 / 8$ & $305(L)$ & 13.1 & 2.8 & 1.956 & HE oriented sontuess \\
\hline
\end{tabular}

\section{RESUI TS AND DISCUSSION}

Experiments involving detonations at locations other than $\mathrm{K}$ for both 1/8-scile and 1/4-scale ure tubulated in Table 4. Experiment 218 resulted in a reflected pressure peak of 11.1 psi at $4.5 \mathrm{~ms}$ after detonation. Ar equal (11.1 psi) pressure peak was observed at $3.4 \mathrm{~ms}$, and a single pressure peak to 13.4 psi occurred late at $6.4 \mathrm{~ms}$.

The three experiments at location $\mathbf{G}$ resulted in an average of 13.4 psi for detonations at this locition. A narrow peak to $16.0 \mathrm{psi}$ occurred late at 7.2 ms on Experiment 227. apparently from a particle hitting the transducer diaphragm. This peak did nut occur on either of the other two experiments (220 and 226) at $G$.

The pressure peak of the first reflected shock wave on Experiment 221 was to 12.3 psi at $3.0 \mathrm{~ms}$ following detonation. A single pressure peak to 12.5 psi occurred carly at $2.6 \mathrm{~ms}$, and a late peak to 16.0 psi was recorded at $4.2 \mathrm{~ms}$ after detonation.

The pressure from detonations at $\mathbf{C}$ and $\mathbf{E}$ were both below the average in these mode's ( $14.0 \mathrm{psi})$ for detonations at $\mathrm{K}$.
After the doorways of the I/8-scale model had been widened, three experiments were conducted to determine the acceptability of handling HE charges at locations D and L. Experiment 303 at D resulted in a peak pressure of 11.8 psi at 3.7 ms. Experiment 304 at L (oriented south) produced a 14.5 psi peak at $4.5 \mathrm{~ms}$, and experiment 305 at $\mathrm{L}$ (oriented southeast) gave 13.1 psi at $2.8 \mathrm{~ms}$ after detonation. All three detonations in the wide-doorway nodel resulted in pressures less than the average of $147 \mathrm{psi}$ for 1-kg equivalent detonations at $K$.

Pressure-versus-time graphs for the preceding experiments are in Appendix $A$.

\section{CONCLUSIONS AND RECOMMENDATIONS}

These results were considered satisfactory for determining cell work-area limitations. With the exception of location $J$ (exprriment 221), detonations at all locations produced reak pressures that were less than the average of those detonated at $\mathbf{K}$. Experiments in the nasrow-doorway models produced pressures less than 14.0 psi, and those in the widedoorway model were less than 14.7 psi. 


\section{EFFECTS OF BLAST WALLS AND BAFFLES: \\ NARROW DOOR MODEL}

\section{PROCEDURE}

Two experiments (203 and 204) were first detonateo near the cell-maze cioorway (at locations $c$ and $f$ in Fig. 2) to deteimine the unbaffled peak reflected pressure at position 1 . Then another $c s-$ periment (205) was conducted at location $\mathrm{c}$ after installing a 0.25-io. steel baffle (BFL) that closed the midpoint sf the maze from the ceiling down to the height of the maze door openings. Two different blast walls were then installed in the cell to cietermine their mitigating effect on the reflected shock pressure at the hallway-maze doorway. Both walls were of 0.25 -in. steel plate, extending from the floor to the seiling, and were secured to the floor and cellmaze wall with 2 by 2 by 0.25 -in. stzel angle and bolts. For experiments 206-211, a 13.5-in. long blast wall (LBW in Fig. 2) was installed. For experiments 212-217, it was replaced with a 7.75-in. short blast wall (SBW). Otherwise, the operating procedure was the same as with other experiments in this $1 / 8$ scale narrow-doorway model.

\section{RESULTS AND DISCUSSION}

Comparing the two experiments at location c (see Fig. 2 and Table 5), the pressure pulse at position 1 was approximately the same for experiment 205 (baffe instailed) as it was for experiment 204 (no baffle).
When experiment 206 (see Tzy,ie 6) wes fired in the temporary doorway formed 4 the LBW, an expectediy high pressure peak to $19.4 \mathrm{psi}, 3.3 \mathrm{~ms}$ after detonation, was sensed by the transducer. When three charges were successively detonated in the centes of the cell at location A (see Table 6), the average peak pressure was 12.6 psi at about $5.3 \mathrm{~ms}$ after detonation. On experiment 207 , the pulse at $5.0 \mathrm{~ms}$ was only one signal wide above 12 psi (to $12.8 \mathrm{psi}$ ) and a single peak pulsed to $15.7 \mathrm{psi}$ at 5.5 ms following detonation. The narrow (doublesignal width) spike above $12.7 \mathrm{psi}$ to $14.7 \mathrm{psi}$ and the single spike on up to 16.0 psi on experiment 209 were considered inconsistent with the other two shots at $A$ and were disregarded in determining the 12.6 psi average peak pressure for detonations at this location. The two experiments at location a, (210 and 211), 3 in. into the cell from the end of the LBW, were both 13.0 psi. On experiment 210, the pressure peak was a single spike above 11.9 psi and on experiment 211, a narrow peak extended on up to 16.4 psi.

With the SBW installed in place of the LBW, the four detonations at $L$ averaged 5.7 psi. For three of these, experiments 212-ż14, side-on pressures were recorded by mounting the transducer in the previously described tapered disk facing perpendicular to the reflected shock front. These readings were converted to equivalent reflected pressures using curves based on the equation ${ }^{2} P_{r} / P_{s o}=2+$

TABLE 5. One-eight-scale experiments near cell-naze doorway (with and withont maze-hallway baffe).

\begin{tabular}{|c|c|c|c|c|c|}
\hline $\begin{array}{c}\text { Exprrineet } \\
\text { ander }\end{array}$ & $\begin{array}{l}\text { Location } \\
\text { of HE } \\
\text { ctange }\end{array}$ & 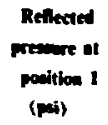 & $\begin{array}{l}\text { The after } \\
\text { detenallea } \\
\text { (10) }\end{array}$ & 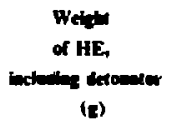 & 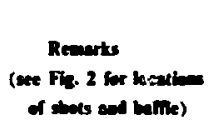 \\
\hline 203 & $\mathbf{r}$ & $1 \mathrm{cs}$ & 2.7 & 1.574 & No watie \\
\hline 204 & e & 220 & 2.7 & 1.974 & $\begin{array}{l}\text { No Mallie } \\
\text { SP to } 20.5 \text { pas at } 3.0 \text { m }\end{array}$ \\
\hline 205 & c & 23.5 & 28 & 1.974 & 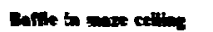 \\
\hline
\end{tabular}


TABLE 6. One-eighth-scale experiments with bhat walls installed.

\begin{tabular}{|c|c|c|c|c|c|}
\hline $\begin{array}{l}\text { Experiment } \\
\text { momber }\end{array}$ & $\begin{array}{l}\text { Conrze } \\
\text { lection } \\
\text { (sece } \\
\text { Fite. 2) }\end{array}$ & $\begin{array}{l}\text { Reflected } \\
\text { mesoure at } \\
\text { pozinlon } 1 \\
\text { (pol) }\end{array}$ & 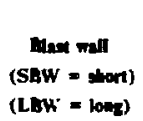 & 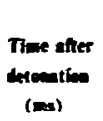 & 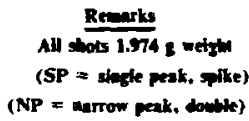 \\
\hline 2006 & 8 & 19.4 & Law & 3.6 & Expexted high presere \\
\hline 207 & $A$ & 12.8 & LEW & $3 . \overline{0}$ & SP to 15.7 mi at $5.5 \mathrm{mot}$ \\
\hline 208 & $\boldsymbol{A}$ & 12.3 & Lew & 5.2 & \\
\hline 205 & $A$ & 12.7 & Low & ss & $\begin{array}{l}\text { NP to } 16.0 \text { psi at } 5.5 \text { ms } \\
\text { (SP above } 14.7 \text { psi) }\end{array}$ \\
\hline 210 & - & 13.0 & LEW & 55 & \\
\hline 211 & a & 13.0 & Low & 56 & NP $1016.4 \mathrm{mit} 5.6 \mathrm{~ms}$ \\
\hline 212 & h & 8.2 & Sawe,c & 48 & $P_{80}=3.8$ pil recorded \\
\hline 213 & $\omega$ & 44 & sow* & 45 & $\begin{array}{l}P_{s 0}=2.1 \mathrm{mal} \text { at } 4.5 \mathrm{as} \\
P_{s c}=28 \mathrm{pi} \text { at } 2.8 \mathrm{ss} \\
\text { recorded }\left(P_{\mathrm{r}}=6.0\right)\end{array}$ \\
\hline 214 & - & 47 & SBW' & 5.4 & 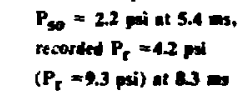 \\
\hline 215 & h & 5.5 & SBY" & 5.3 & $P_{r}=6.2 \mathrm{mil} / 7.2 \mathrm{~ms}$ \\
\hline 216 & 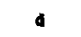 & is.t & SBW" & 3.6 & \\
\hline 217 & e & 10.2 & SBW" & 3.6 & \\
\hline
\end{tabular}

Faline celline.

"No the celling.

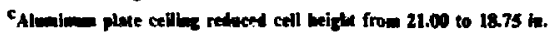

$P_{\text {so }} /\left(7.2+P_{\text {so }} / 6\right)$. An aluminum plate ceiling panel that lowered the effective ceiling height of the cell from 21.00 to $18.75 \mathrm{in}$. was installed for experiments $212,213,215,216$, and 217 . The ceiling height for experiment 214 was 21 in. At location d ( 3 in. from the wall in line with the SBW), the pressure peaked to $15.8 \mathrm{psi}$ at $3.6 \mathrm{~ms}$ and again to $14.7 \mathrm{psi} 1.6 \mathrm{~ms}$ later. On experiment 217 at location e (6.5 in. from the wall in line with the SBW), the pressure peaked to only 10.2 psi at 3.6 ms. Pressure-versus-time graphs for these experiments are in Appendix $A$.

\section{SUMMARY AND CONCLUSIONS}

Comparison of experiments 204 and 205 lead to the conclusion that baflles in the maze ceiling had negligible effect on the peak reflected shock pressure at the hallway-maze doorway.

We also concluded that blast walls betwein the detonation (accidental explosion) location and the maxe doorway were quite effective in mitigating the reflected shock pressure at tise hallway-maze doorway. If an accident occurred near the end of the blast walls, the pressure at the hallway-maze doorway would probably be higher than it would be if the blast wall was not there. We do not iecommend revision of the cell design to incorporate either blast walls or baffles. For this series, lowering of the cell ceiling had no apparent effect on the reflected shock pressure of concern.

\section{HALLWAY PRESSURE PROFILE}

\section{PROCEDURE}

Transducer 3, mounted in the tapered disk described under Inatrumentation, was centered 5 in. above the floor in the hallway of the wide-doorway model at predeterminis distances from the doorway centerline. These distances (positions $z, w, y$, and $x$ in Fig. 2) were 5, 6, 10 and 15 in., equivalent to 3.3, 
TABLE 7. Hallway prewure profite, wile doorway.

\begin{tabular}{|c|c|c|c|c|}
\hline $\begin{array}{l}\text { Trasatucer } 3 \\
\text { position } \\
\text { (see Fth- 2) }\end{array}$ & $\begin{array}{l}\text { Dintance fron } \\
\text { centerlibe of } \\
\text { doomey (b.) }\end{array}$ & $\begin{array}{l}\text { Avertise mealk } \\
\text { reflected } \\
\text { premere (y) }\end{array}$ & $\begin{array}{l}\text { Average tine } \\
\text { after detcontion } \\
\text { (ms) }\end{array}$ & All detconilow at $\mathrm{K}$. \\
\hline $\mathbf{x}$ & $\mathbf{5}$ & 48 & 3.4 & Experinents 301, 302, 313 \\
\hline$w$ & 6 & 5.8 & 3.2 & Experienems 316-321 and 327-329 \\
\hline $\mathbf{y}$ & 10 & 4.7 & S.1. & $\begin{array}{l}\text { Exprimens 259. 390, 3e6. } \\
311,314, \text { and } 323\end{array}$ \\
\hline$x$ & 15 & 5.2 & 6.2 & Experinemes 300-310 \\
\hline
\end{tabular}

4.0, 6.7 and $10.0 \mathrm{ft}$ full-scale, respectively. The tapered disk was randomly oriented parallel and perpendicular to the hallway centerline.

\section{RESULTS AND DISCUSSION}

The average results of peak reflected pressures are listed in Table 7 . The highest pressure recorded during this 20-experiment series was a narrow peak to $8.1 \mathrm{psi}$ on experiment 320 at position $w$ ( 6 in. from the doorway centerline). No meaningful profile was apparent from a preliminary plot of ex- perimental data. Graphs of pressure-versus-time for individual experiments are in Appendix B.

\section{CONCLUSIONS AND RECOMMENDATIONS}

The peak reflected pressure dissipates rapidly once it exits the hallway-maze doorway. The peak reflected pressure resulting from a $\mathbf{1 - k g}$ detonation in the cell would not be expected to exceed the specified maximum of 10 psi beyond 6 in. ( $4 \mathrm{ft}$ fullscale) from the doorway centerline.

\section{DETERMINATION OF CELL EXPLOSIVE LIMIT}

When model testing was initiated, the specified maximum allowable peak reflected pressure at the hallway-maze doorway was 15 psi. Before testing was completed, however, the pressure limit was reduced to 10 psi and it was necessary to widen the doorways. Account must aiso be taken of the fact that an accidental detonation would probably be randomly oriented, and preliminary explosive limits had been determined with all test charges facing toward the south.

\section{PROCEDURE}

To determine the cell explosive limit, certain conditions were met.

- We developed an empirical equation
(pressure-versus-HE charge weight) to fit the peak reflected pressures from reduced and full $1-\mathrm{kg}$ equivalent charges detonated at $\mathrm{K}$, nriented south, in the narrow-doorway models.

- Based on similar reflected pressures at the hallway-maze doorway of the wide-doorway model, another empirical equation was developed to account for widening the maze doorways from $2 \mathrm{ft} .4 \mathrm{in}$. to $2 \mathrm{ft} 8$ in.

- This equation was then shifted upward, in the ratio of the average peak pressure resulting from rondomly oriented charges at $K$ (17.5 psi) to the average from $K$ south-oriented charges at $K$ (14.7 psi), in the wide-doorway model.

- Where the plot of the resulting equation crossed the 10 psi pressure line determined the maximum permissible cell explosive limit. 


\section{RESULTS AND DISCUSSION}

\section{Devdlopment of the Basic Empirical Equntion}

High Explosive charges equivalent to approximately 1.0, 0.8-, 0.7-, 0.5-, and 0.3-kg full-scale were detonated at $K$ (oriented south) in tili: $1 / 4$ scale and in the 1/8-scale models (both narrow and wide doorways). The normal operating procedure was followed and peak pressures at position 1 were recorded in Tables 8 and 9, and piotted in Figs. 8 and 9.

Net pellet weights were determined by cuberoot scaling, including consideration of the $0.021-\mathrm{g}$ weight of the $\mathrm{M} 195 \mathrm{iA}$ detonator used. For the 500-g equivalent for experiment 232 in the $\mathrm{I} / 4$-scale

TABLE 8. Reduced explosive series, narrow-doorway models.

\begin{tabular}{|c|c|c|c|c|c|c|c|}
\hline \multirow[b]{2}{*}{$\begin{array}{c}\text { Experimeat } \\
\text { naber }\end{array}$} & \multirow[b]{2}{*}{$\begin{array}{l}\text { Model } \\
\text { seate }\end{array}$} & \multicolumn{3}{|c|}{ Explodive weidh (a) } & \multirow{2}{*}{$\begin{array}{l}\text { Peal } \\
\text { reflected } \\
\text { preasere } \\
\text { (pw) }\end{array}$} & \multirow{2}{*}{$\begin{array}{l}\text { Time after } \\
\text { detonation } \\
\text { (as) }\end{array}$} & \multirow{2}{*}{$\begin{array}{l}\frac{\text { Rewarks }}{\text { (SP }=\text { single peak) }} \\
(\mathrm{NP}=\text { sarrom peak })\end{array}$} \\
\hline & & Actial & $\begin{array}{l}\text { Seale } \\
\text { factor }\end{array}$ & $\begin{array}{l}\text { Eqphalex } \\
\text { folltecale }\end{array}$ & & & \\
\hline 235 & $1 / 4$ & 8.646 & 64 & 291,34 & 3.8 & 7.3 & $\begin{array}{l}\text { SP to } 4.2 \mathrm{pal}=1.2 \mathrm{~ms} \\
N P \text { to } 4.7 \mathrm{~ms} \text { at } 12.7=\end{array}$ \\
\hline 232 & $1 / 4$ & 7.832 & 64 & 501.25 & 6.3 & 6.6 & SP to $6.6 \mathrm{paj}$ at $5.5 \mathrm{~m}$ \\
\hline 203 & $1 / 4$ & 10.339 & 64 & 661.70 & 8.7 & 6.4 & $\begin{array}{l}\text { SPs to } 8.9 \text { wi at } 8.2 \mathrm{~m} \\
\text { and at } 11.0 \mathrm{~ms}\end{array}$ \\
\hline 236 & $1 / 4$ & 12.406 & 64 & 793,98 & 10.0 & 6.2 & SP to 10,3 psi at $6.6 \mathrm{~ms}$ \\
\hline Avenage" & $1 / 4$ & (15,605) & 64 & $(1001.28)$ & $(14.0)$ & $(5.9)$ & \\
\hline 265 & $1 / 8$ & 0.584 & 512 & 299.01 & 2.8 & 3.2 & NP to 3.7 pal at $1.8 \mathrm{~ms}$ \\
\hline 264 & $1 / 8$ & 0.977 & $\mathbf{5 1 2}$ & 500.22 & 5.9 & 3.0 & SP to 7.1 psi at 1.8 : \\
\hline 263 & $1 / 8$ & 1.292 & 512 & 661.50 & 7.6 & 29 & NP to 8.9 yad at 4.6 wa \\
\hline 264 & $1 / 8$ & 1.545 & 512 & T91.04 & 10.8 & 2.8 & SP to $1.8 \mathrm{pai}$ at $2.6 \mathrm{~ms}$ \\
\hline Average & $1 / 8$ & (1.950) & 512 & $(930.40)$ & $(14,0)$ & (2.9) & \\
\hline
\end{tabular}

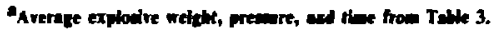

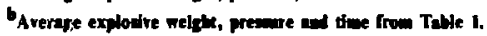

Notes: All chryes ixtonted at Location K, oricated anth.

Date wotted is Fis. B.

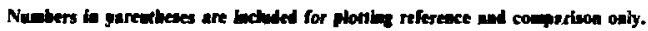

TABLE 9. Reduced explosive series, 1/8-scale wide-doorway model.

\begin{tabular}{|c|c|c|c|c|c|}
\hline \multirow[b]{2}{*}{$\begin{array}{l}\text { Experiment } \\
\text { number }\end{array}$} & \multicolumn{3}{|c|}{ Explosive churge welyhs (g) } & \multirow{2}{*}{$\begin{array}{l}\text { Peak } \\
\text { reflected } \\
\text { presure } \\
\text { (pi) }\end{array}$} & \multirow{2}{*}{$\begin{array}{l}\text { Time after } \\
\text { detconation } \\
\text { (ns) }\end{array}$} \\
\hline & Actual & $\begin{array}{l}\text { Seate } \\
\text { factor }\end{array}$ & $\begin{array}{l}\text { Eepivaleat } \\
\text { full-acale }\end{array}$ & & \\
\hline 280 & 0.585 & 512 & 299.52 & 2.7 & 3.2 \\
\hline $2 \%$ & 0.978 & 512 & 50.74 & 6.0 & 3.1 \\
\hline 290 & 1.291 & 512 & 660.99 & 85 & 2.9 \\
\hline 291 & 1.547 & 512 & 19286 & 11.7 & 2.9 \\
\hline Averaye & (1.582) & $\mathbf{s 1 2}$ & $(9,9,42)$ & $(14,7)$ & $(2.7)$ \\
\hline
\end{tabular}

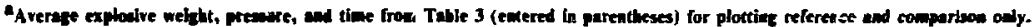

Note: Alove date plotted in Fi: 9. 


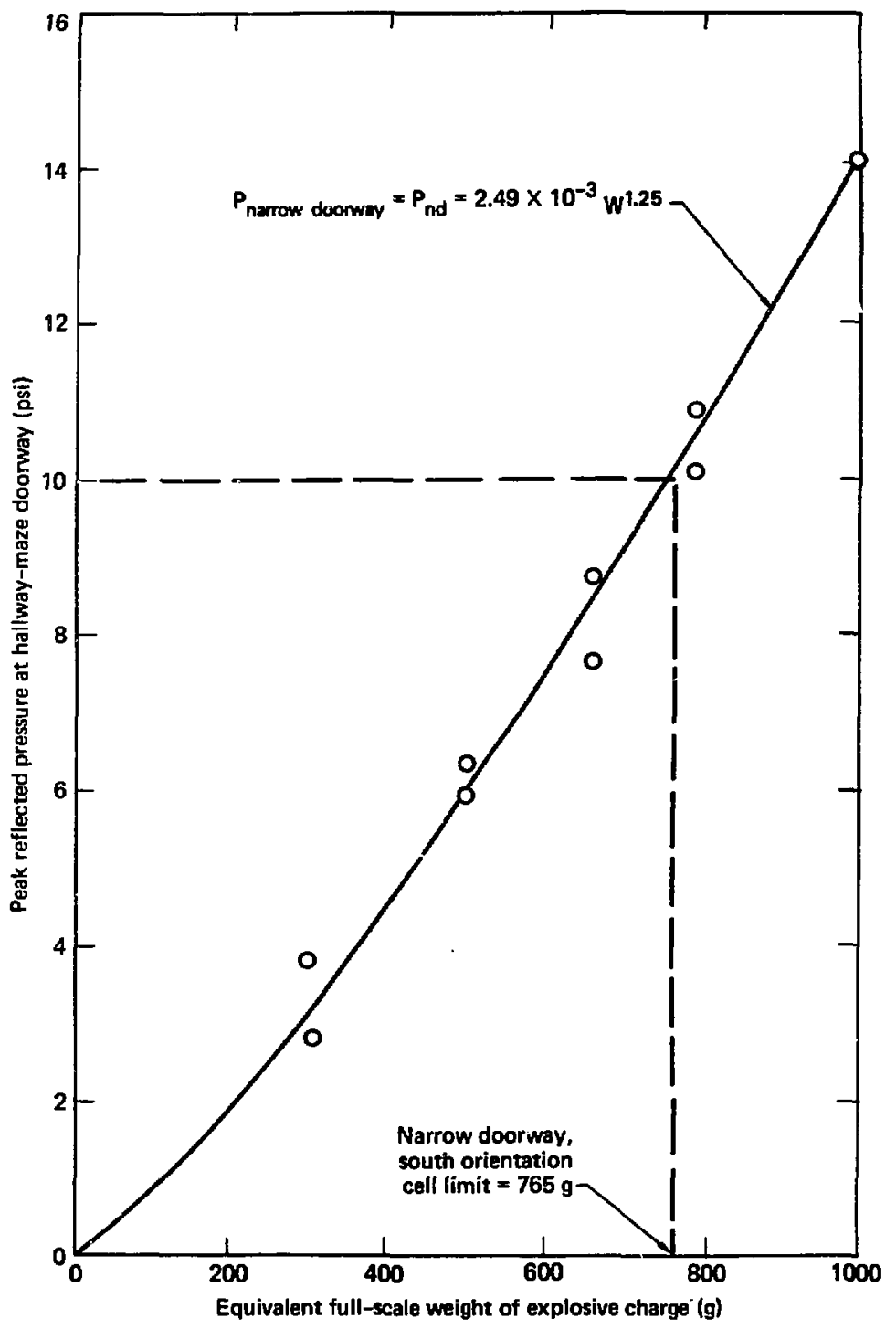

FIG. 8. Cell explosive limit, marrow doorway, south orientation. 


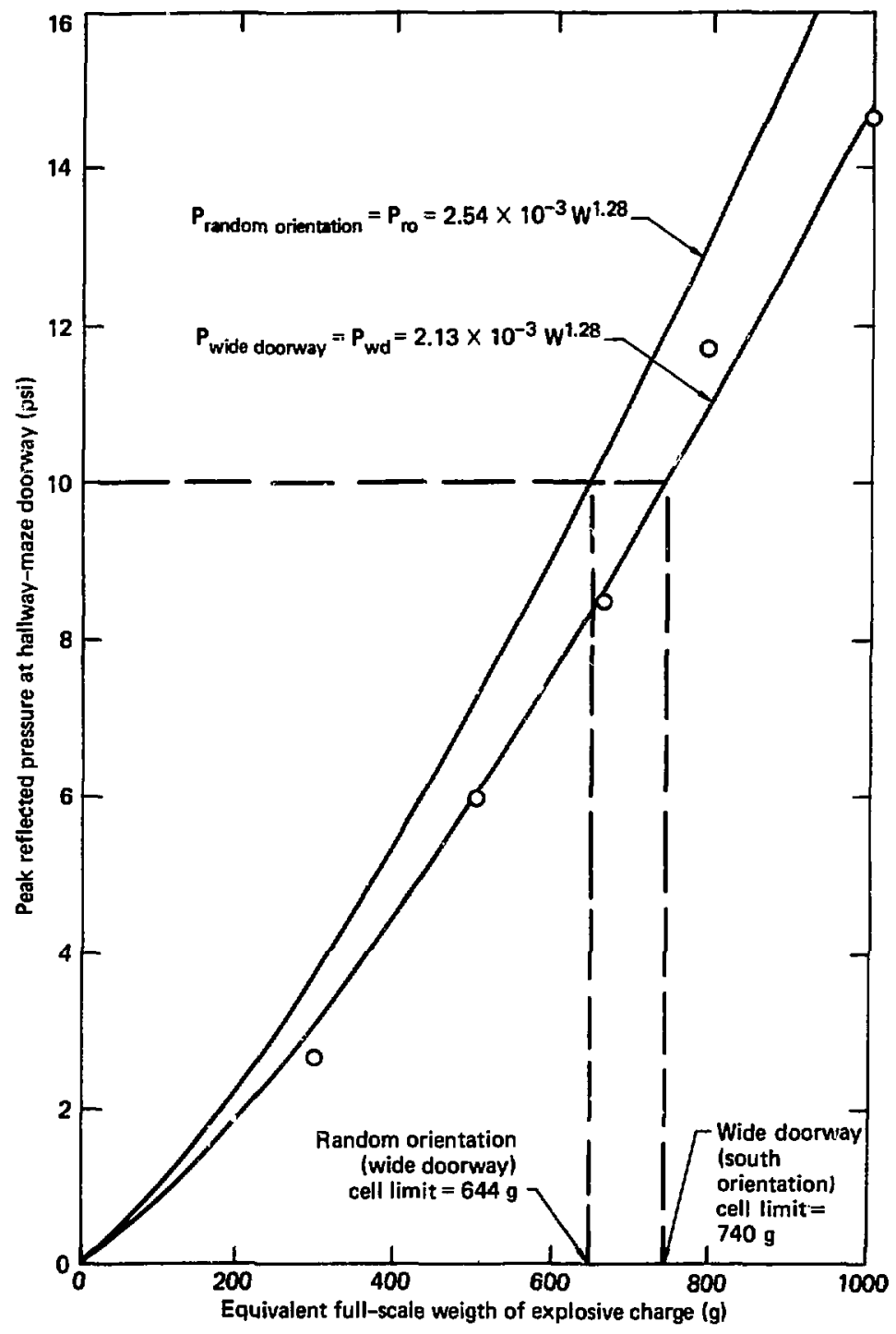

FIG. 9. Cell explosive limit, wide doorway, random orientation. 
model, for example, the pellet weighed approximately $\left[\left(500 / 4^{3}\right)-0.021\right]$ or $7.792 \mathrm{~g}$ (actually $7.832 \mathrm{~g}$ ). Fo: the $800 \mathrm{~g}$ equivalent for experiment 262 in the 1/8-scale model, the pellet weighed approximately $\left[\left(800 / 8^{3}\right)-0.021\right]$ or $1.542 \mathrm{~g}$ (actually $1.545 \mathrm{~g}$ ). All biE charges were of PBX 9407 assembled to MC 1957A detonators, as previously described.

The single and narrow pressure peaks that complicated rational analysis of the experimental data are listed under Remarks in Table 8. Due to their typical occurrence early, during a period of increasing impulse, or very late, they were disregarded in comparing the pertinent peak reflected pressures.

Figure 8 plotted from the experimental data in Table 8 shows the close correlation between reflected pressure measured on narrow-doorway 1/8-scale and 1/4-scale model experiments with reduced explosive charges. The standard deviation of plotted daia is +0.44 psi from the empirical equation generated from this data: $P_{\text {nd }}=2.49 \times 10^{-3} \mathrm{~W}^{1.25}$, where $P_{n d}$ is the peak reflected pressure at the hallway-maze doorway in psi and $W$ is the total weight of the full-scale HE charge in grams. Figure 8 indicates that the explosive limit for a narrowdoorway cell would be about $765 \mathrm{~g}$. The widedoorway curve in Fig. 9 plotted from the data in Table 9 shows the similarly close correlation between the pressures st:nsed on the wide-doorway 1/8-scale model experiments (with reduced explosive charges) and the equation developed to account for doorway widening. This equation is: $P_{\text {wd }}$ $=2.13 \times 10^{-3} \mathrm{~W}^{1.28}$, which indicates an explosive limit of $740 \mathrm{~g}$ for south-oriented detonations in a wide-doorway cell. The standard deviation of the experimental data from this recalculated curve is \pm 0.41 psi.

Expected decrease in transit times for increased weight of explosive charges, as consistently evidenced in both Tables 8 and 9 , attests to the reliability of the recorded data.

\section{Effect of Whdening Maze Doorways}

The average peak reflected pressure sensed in bath the 1/8-scale and 1/4-scale models with maze doorways modelec to 2 ft 4 in. (narrow) was compared to the average recorded for the $1 / 8$-scale model after the doorways were widened to $4.0 \mathrm{in}$. to represent 2-ft-8-in. (wide) doorways. An empirical equation was developed to describe the relationship between the peak reflected pressures from reduced and full-scale equivalent charges detonated in the wide-doorway $1 / 8$-scale model.

The average peak reflected pressure for both the 1/8-scale and 1/4-scale narrow-doorway models for south-oriented detonations at location $\mathbf{K}$ was $14.0 \mathrm{psi}$, as listed in Tables $t$ and 2 . The average for similar detonations at $K$ in the $1 / 8$-scale widedoorway model was 14.7 psi (Table 3).

The empirical equation, $P_{w d}=2.13 \times 10^{-3}$ $\mathrm{W}^{1.28}$ can be used to predict the peak reflected pressure (in psi) at the hallway-maze doorway for any south-oriented charge $W$ (in grams). The peak reflected pressure from any accidental, southoriented detonation within the cell working area (shown in Fig. 2) should not exceed this calculated pressure.

\section{Effect of Randomby Orienting HE Charges}

Equivalent $1-\mathrm{kg}$ charges were oriented at $\mathrm{K}$ so that explosive propagation was toward the north, east, or west rather than toward the south, to determine the effect of charge orientation on the peak reflected pressure at the hallway-maze doorway. See Fig. 2 for charge locations and orientations.

The average of the maximum peak pressures for charges randomly oriented (north, east, and west) was $17.5 \mathrm{psi}$ at an average time after detonation of $2.7 \mathrm{~ms}$. shown in Table 10 .

The result of moving the wide-doorway equation upward in the ratio of 17.5:14.7 from $P_{w d}=$ $2.13 \times 10^{-3} \mathrm{~W}^{1.28}$ to $P_{\text {ro }}=2.54 \times 10^{-3} \mathrm{~W}^{1.28}$ (to conservatively account for the probability of an accidental detonation being randomly oriented) is shown in Fig. 9. The weight limit of PBX 9407 to be handled in the l-kg cells is therefore $644 \mathrm{~g}$ (1.42 lb) to prevent the peak reflected pressure at the hallway-maze doorway from exceeding 10 psi.

\section{CONCLUSIONS}

\section{PROOF OF SCALING}

To show that results of testing in a $1 / 8$-scale model can be reliably extrapolated to the full-scale
HEAF cell, we constructed the 1/4-scale model and conducted experiments based on the cube-root scaling relationship $W_{m}=\left(V_{m} / V_{f}\right) W_{f}$, where $W_{m}$ is the 
TABLE 10. One-kg, wide-doorway-charge orlentution experiaents at location $K$.

\begin{tabular}{|c|c|c|c|c|c|}
\hline \multirow{2}{*}{$\begin{array}{l}\text { Experimeat } \\
299\end{array}$} & \multicolumn{2}{|c|}{ 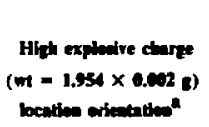 } & \multirow{2}{*}{$\begin{array}{l}\text { Reflectod } \\
\text { promme at } \\
\text { pention I } \\
\text { (ped) } \\
184\end{array}$} & \multirow{2}{*}{ 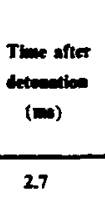 } & \multirow{2}{*}{ 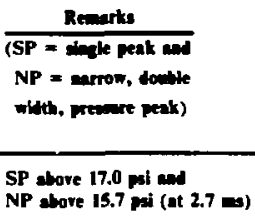 } \\
\hline & $\mathbf{k}$ & ent & & & \\
\hline 301 & $\mathbf{x}$ & worth & 17. & 2.6 & $\begin{array}{c}\text { SP wove } 10.5 \text { psi to } 17.4 \text { mi } \\
\text { at } 1.0 \text { ms and NP albove } 14.7 \\
\text { mi (at } 2.6 \text { ma) }\end{array}$ \\
\hline 302 & $\mathbf{K}$ & $\operatorname{men}$ & 16.9 & 2.9 & $\begin{array}{l}\text { NP to } 17.5 \mathrm{mlal} \text { at } 1.4 \mathrm{~ms} \text { amd } \\
\text { SP thove } 15.4 \text { pil (at } 2.9 \mathrm{~ms})\end{array}$ \\
\hline \multicolumn{3}{|c|}{ Aterage maxima for location K, ravdon: } & 17.5 & 2.7 & $\begin{array}{l}\text { Use for settiss comervative } \\
\text { cefl lisitations }\end{array}$ \\
\hline
\end{tabular}

See Fig. 2 for theotion of explodive propagation.

weight of explosive detonated in the model, $W_{\mathrm{f}}$ is the equivalent full-scale explosive charge weight, $V_{m}$ is the volume of the model, and $V_{f}$ is the volume of the proposed cell.

Comparison of south-oriented detonations at $K$ in the 1/4-scale and 1/8-scale narrow-doorway models proved that cube-root scaling of the fullscale cell-maze was reliable. The average peak reflected pressure at the hallway-maze doorway in both models was $14.0 \mathrm{psi}$. This pressure was recorded at an average time interval of $2.9 \mathrm{~ms}$ after detonation of the explosive charge for experiments in the 1/8-scale model (Table 1 ) and at about twice the time interval, $5.9 \mathrm{~ms}$, in the $1 / 4$-scale model (Table 2).

\section{CELL WORK-AREA LIMITATIONS}

By detonating charges in selected locations inside the narrow-doorway model cells, we determined that cell-limit quantities could be handled within the area shown shaded in Fig. 2. This includes all floor space to within $2 \mathrm{ft}$ of the wall except for the area within a $4 \mathrm{ft}$ radius of $F$, near the cellmaze doorway.

\section{CELL EXPLOSIVE LIMIT}

Peak pressure-versus-charge weight for experiments in the narrow-doorway models were plotted and the empirical equation $P_{n d}=2.49 \times 10^{-3} \mathrm{~W}^{1.25}$ was developed to calculate the peak pressure at the hallway-maze doorway for the detonation of various $\mathrm{HE}$ charges.

Midway through testing, when we were told that the cell doorway must be wider, this equation was revised to $P_{w d}=2.13 \times 10^{-3} \mathrm{~W}^{1.28}$ to account for widening of the doorways.

The resulting equation for reflected pressure was finally adjusted to $P_{r o}=P_{r}=2.54 \times 10^{-3} \mathrm{~W}^{1.28}$ to recognize the probability that an accidentally detonated charge could be randomly oriented.

The cell explosive limit, the weight of HE that could credibly cause a peak reflected pressure of 10 psi at the hallway-maze doorway of the proposed cell, is $644 \mathrm{~g}$ or $1.42 \mathrm{lbs}$.

Peak pressures from ": a! "way transducers at full-scalc equivalent distances of $4 \mathrm{ft}$ and over from the doorway centerlina were all less than $10 \mathrm{psi}$ when randomly oriented $1-\mathrm{kg}$ equivalen $i$ charges were detonated in the wide-doorway cell model. If charges in excess of the cell limit are to be handled in the cell, the hallway within $4 \mathrm{ft}$ of the doorway must be administratively restricted or barricaded to control personnel access. 


\section{REFERENCES}

1. Theodore Baumeister, Marks Mechanical Engineers Handbook (McGraw-Hill Book Company, New York, NY. 1958), oth ed., pp. 2-32-2-33.

2. N. M. Newmark. Separate No. 306, in Proc. Amer. Soc. Civil Engr.. Vol. 79, Oct. 1953. 


\section{APPENDIX A. SAMPLE PRESHOT RECORD: \\ 1/8-SCALE MODEL}

Test date: $9-4-80$

Crew:

Test number: $\underline{260}$

Electronics: Ken Griffin

Explosives: Terry Harris

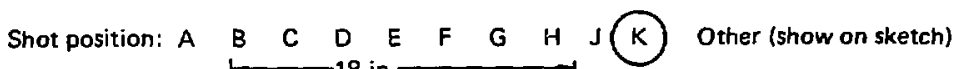
\begin{tabular}{|r|r|}
\hline-9 in. 18 in. & 1 \\
\hline$E$ & 3 in \\
\hline
\end{tabular}

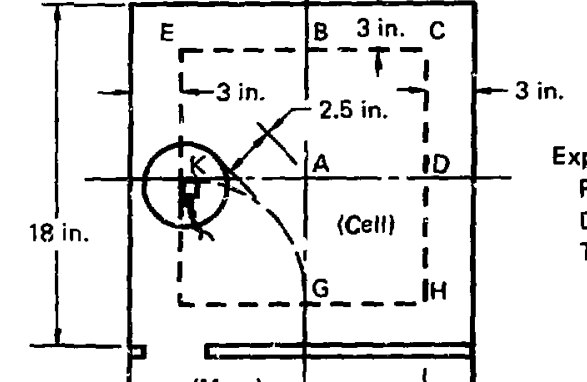

Explosive weight (grams)

Pellet : 1.932

Detonator: $\overline{0.021}$

Total shot: $\underline{1.953}$

Transducer information: Transducer Cable

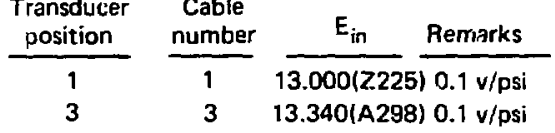

Comments;

Same as 257-259 except Tdcr 3 moved to $10^{\prime \prime}$ from doorwaye. Tder 3 in tapered disk.

Ramrod (initials): CMB 


\section{APPENDIX B. \\ GRAPHS OF PRESSURE VERSUS TIME}

On the following graphs of original field data, time is indicated in hundredths of seconds (seconds $X$ $10^{-2}$ ) and pressure is shown in volts.

To convert time to milliseconds, the printed number was multiplie' times 10 . To rer.t the pressure in psi, the printed number was aiso mittiplied times 10 .

6/2/80 2:0OP.M.

EO

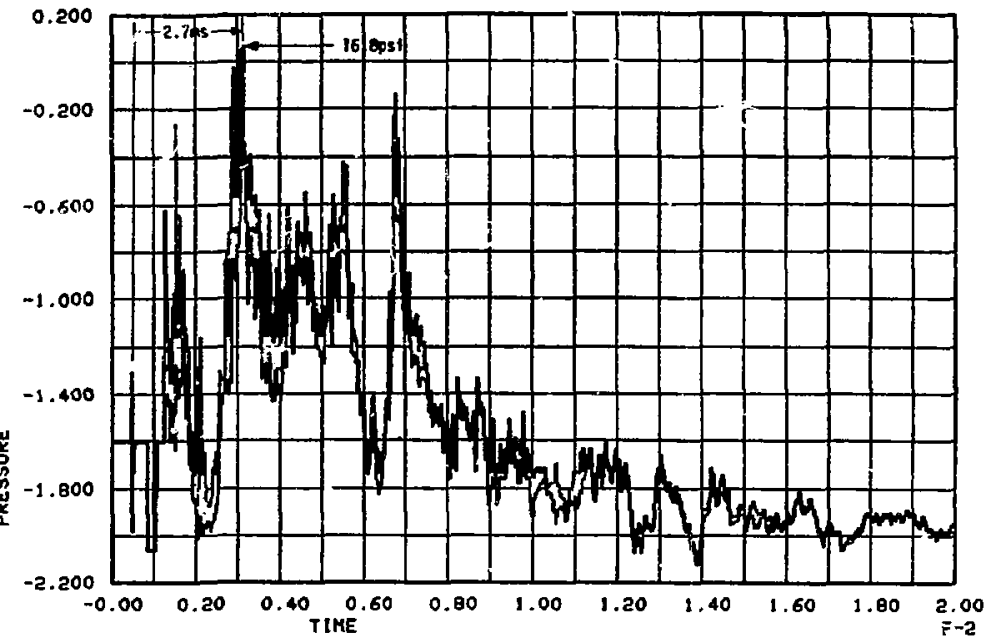

HEAF 203 POSITION *I 
5/2/80 2:15P.N.

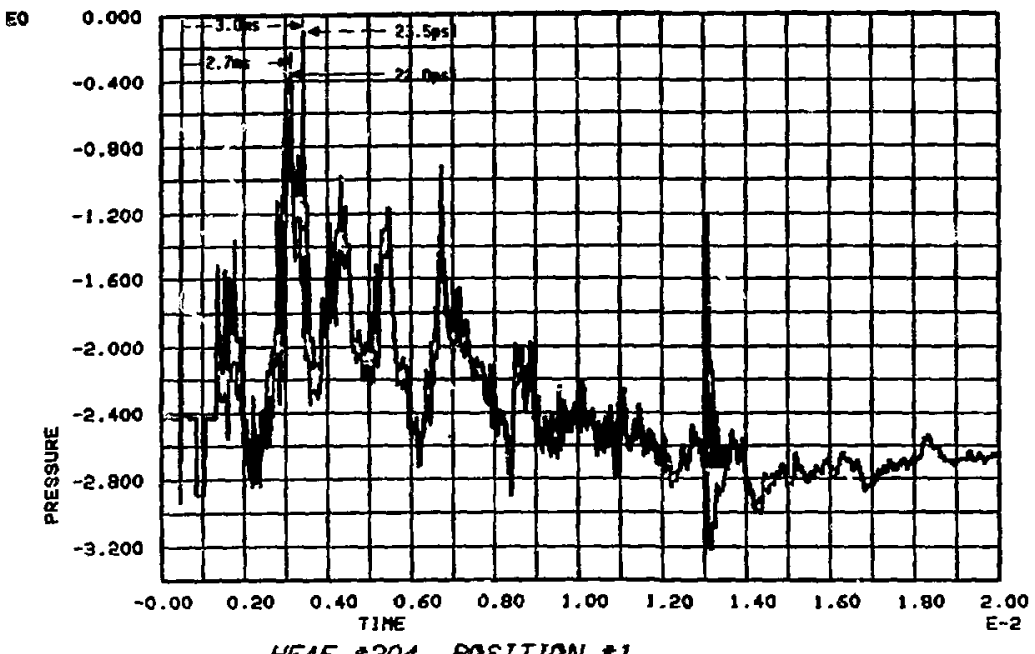

HEAF :204 POSITION *I

5/2/80 3,00P.H.

E0

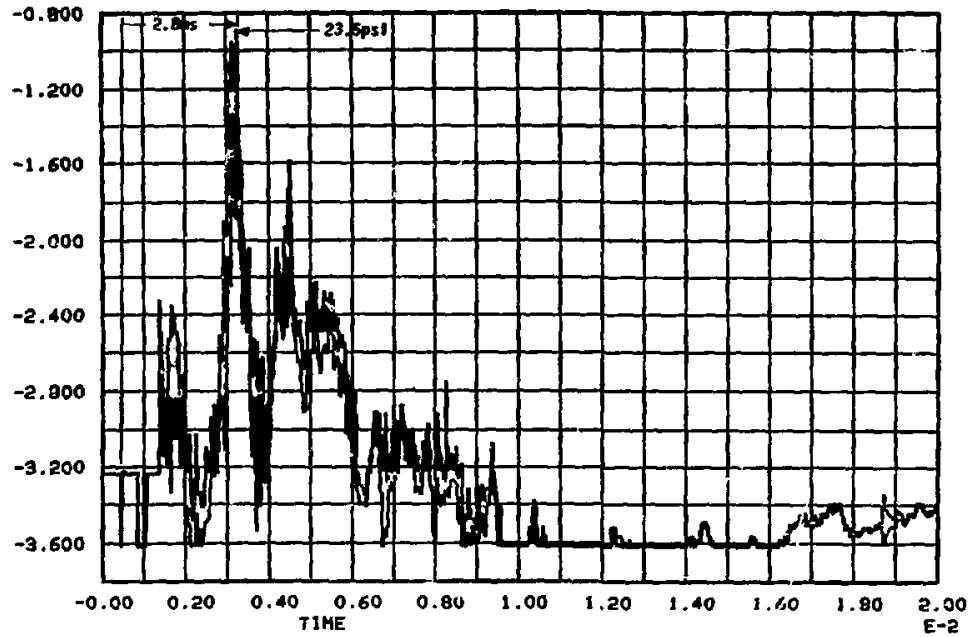

HEAF 205 POSITION 1 


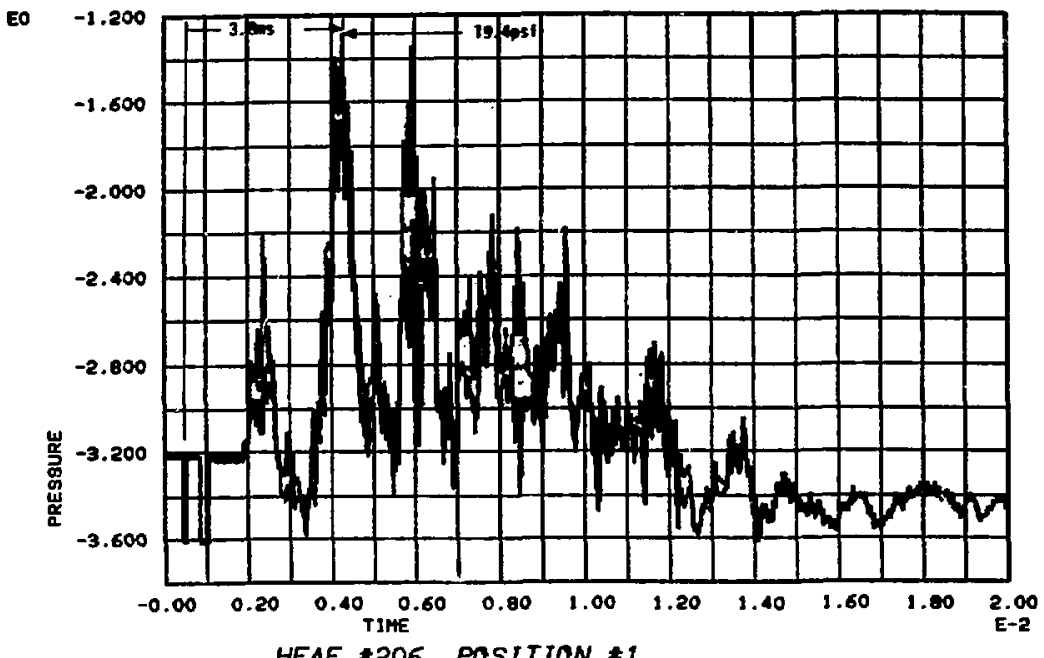

6/14/60 11,00A.M.

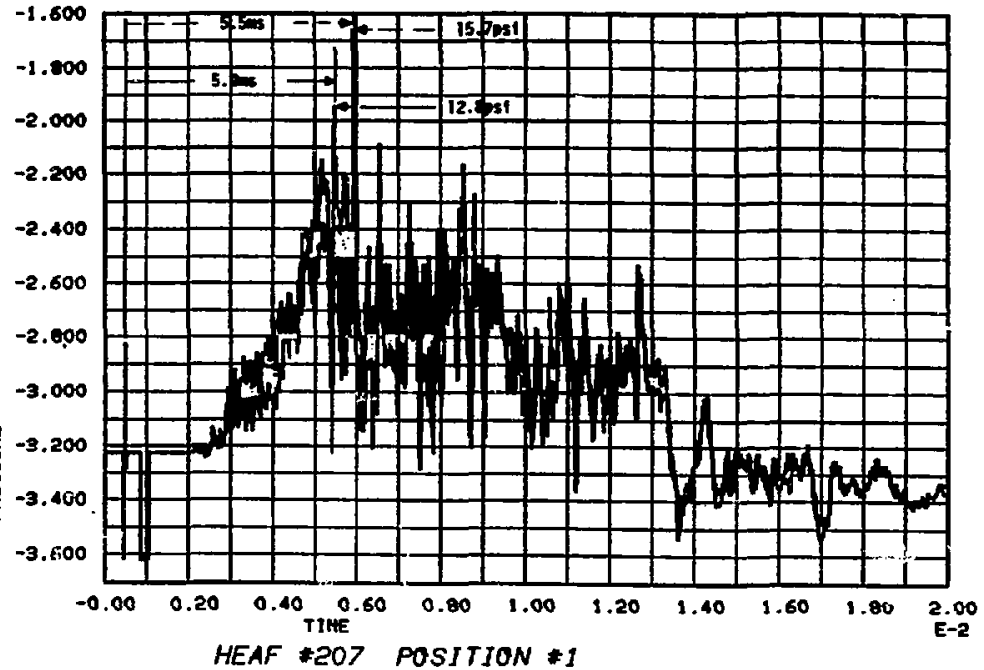


EO

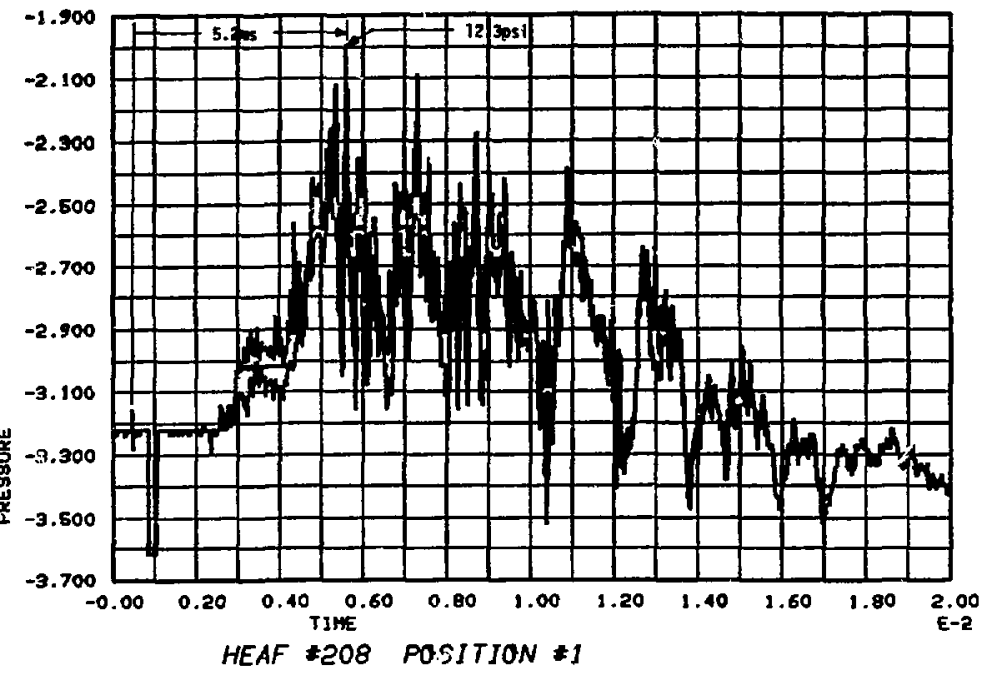

$5 / 14 / 80 \quad 14: 00$

EO

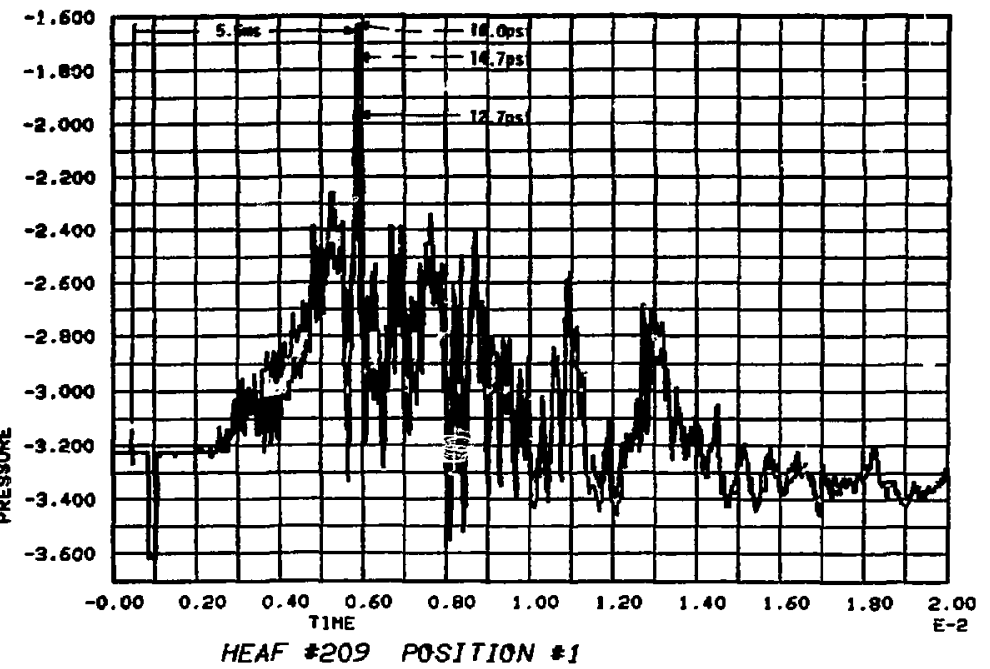



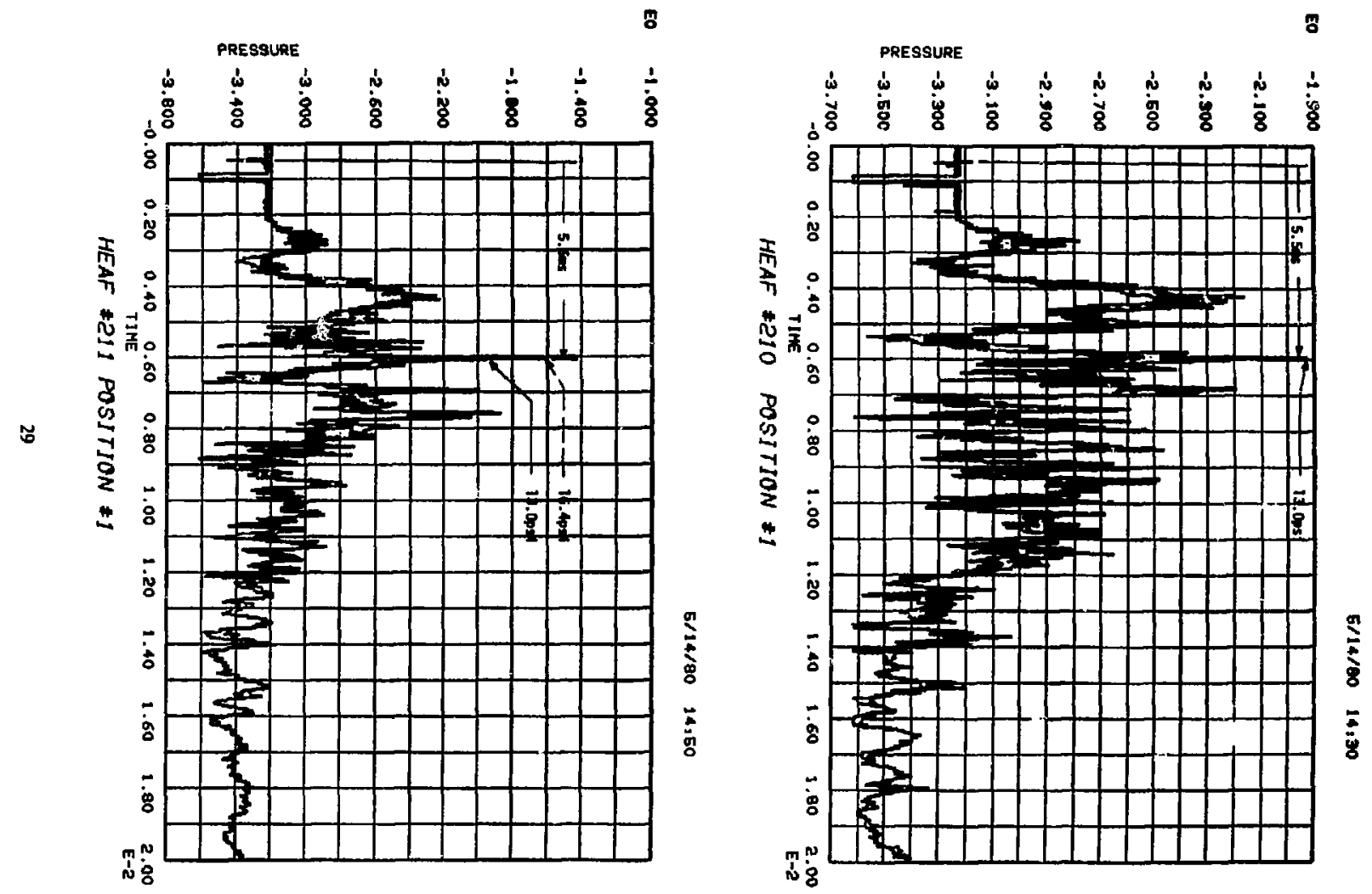
EO

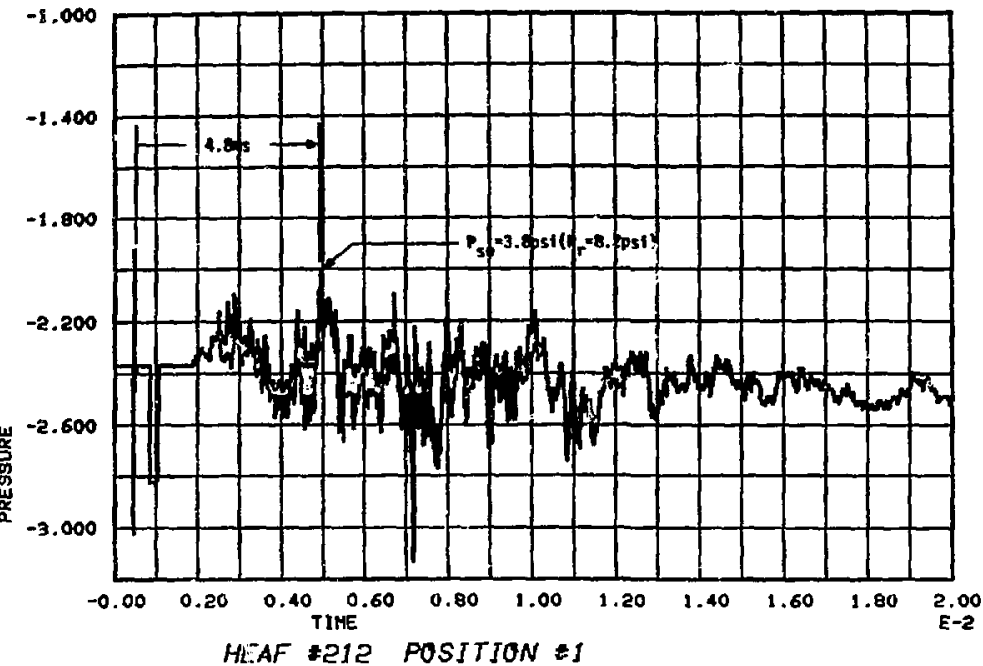

6/4/80 10,35A.M.

EO

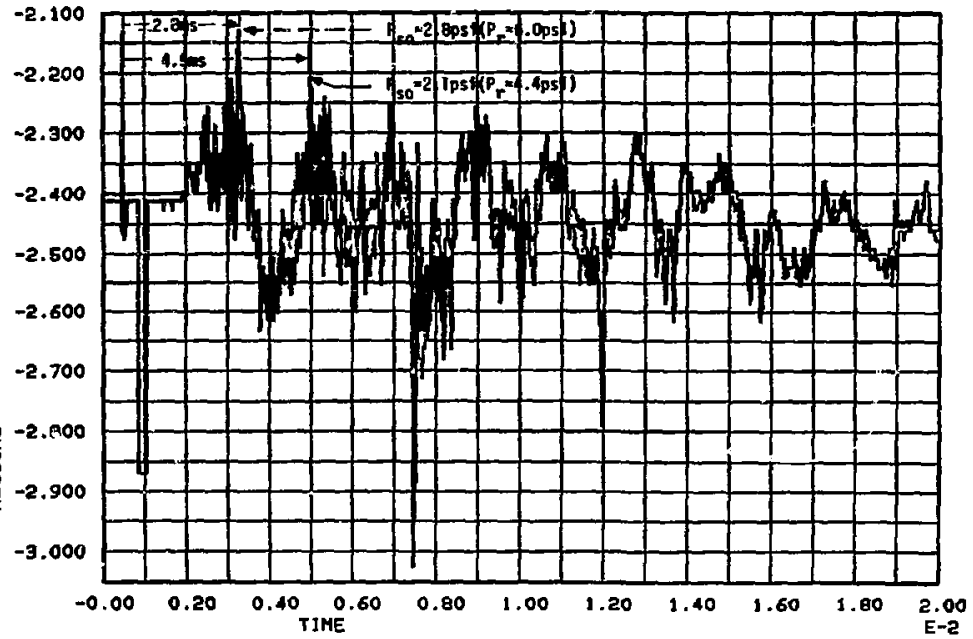

HEAF \#213 POSITION *I 


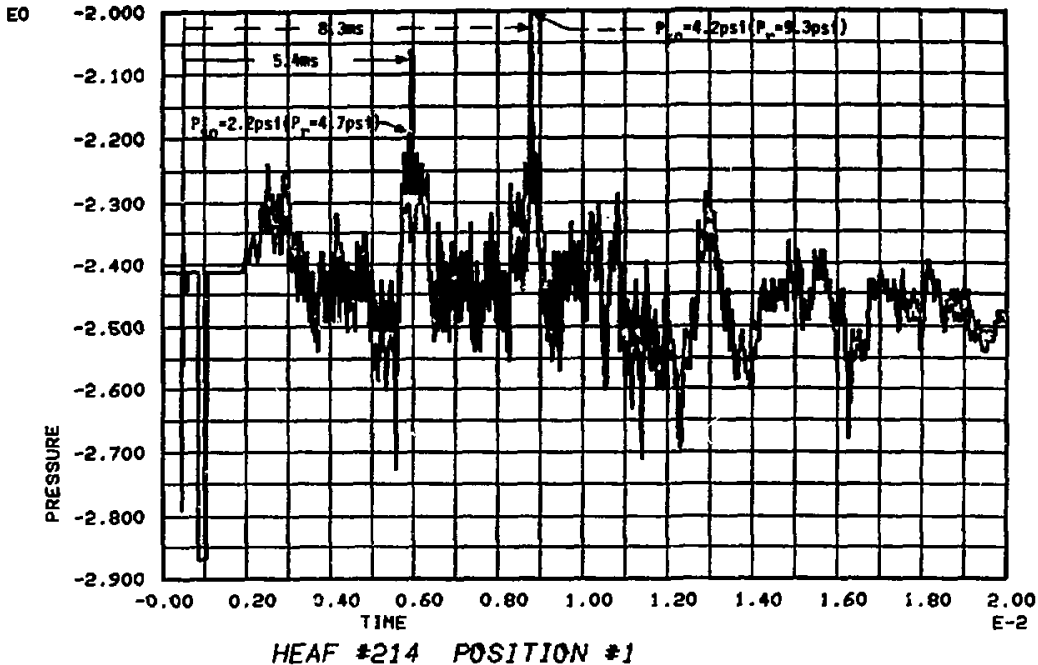

$6 / 4 / 60 \quad 14,15$

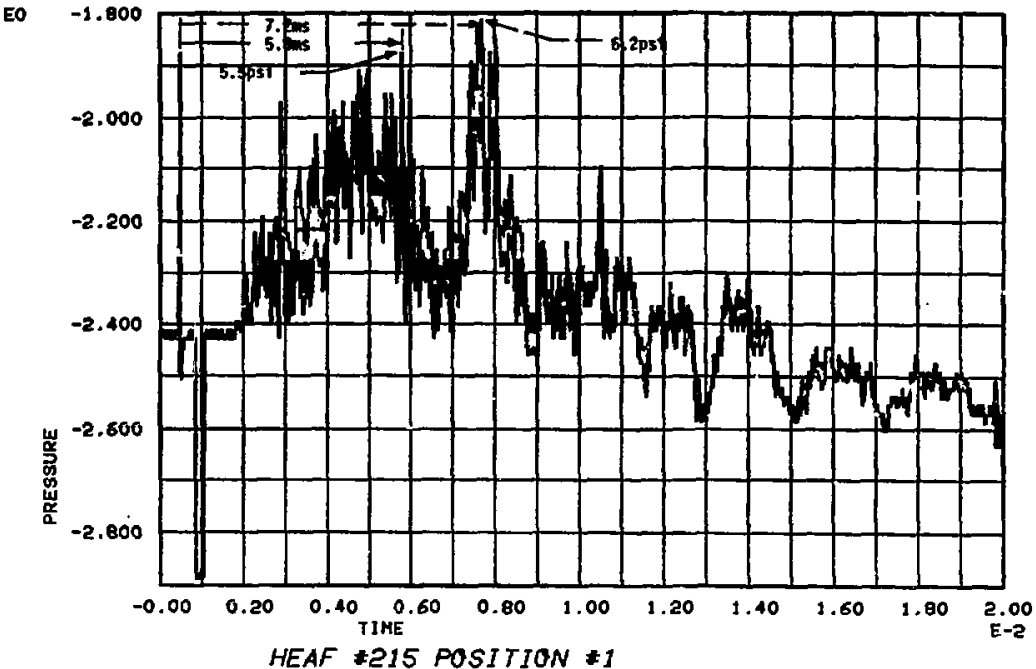




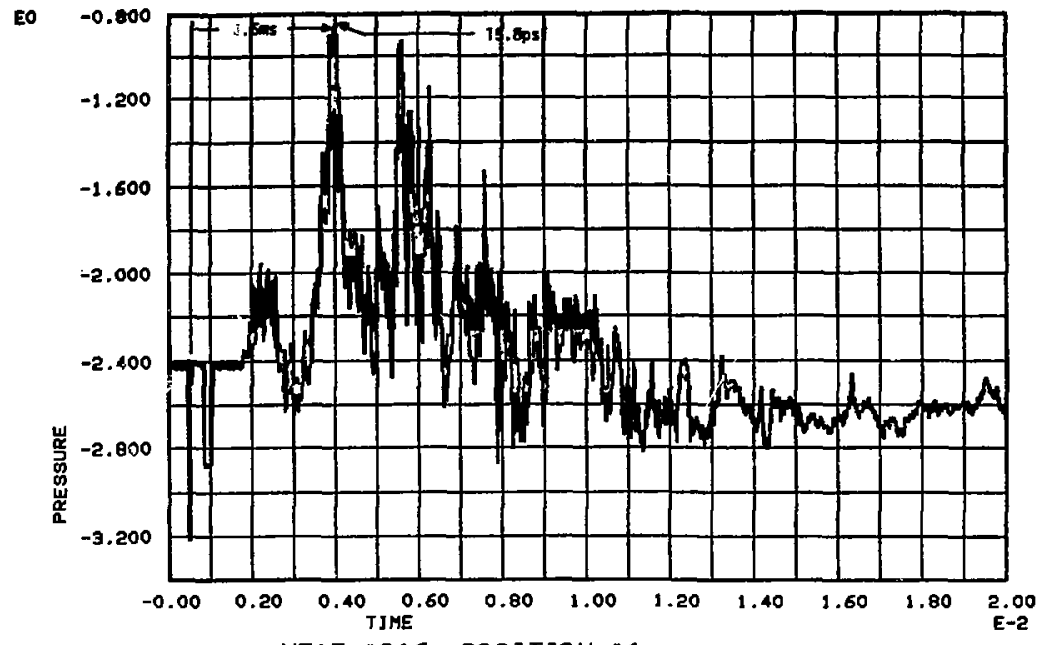

HEAF *216 POSITION *1

$6 / 4 / 80 \quad 16,00$

EO

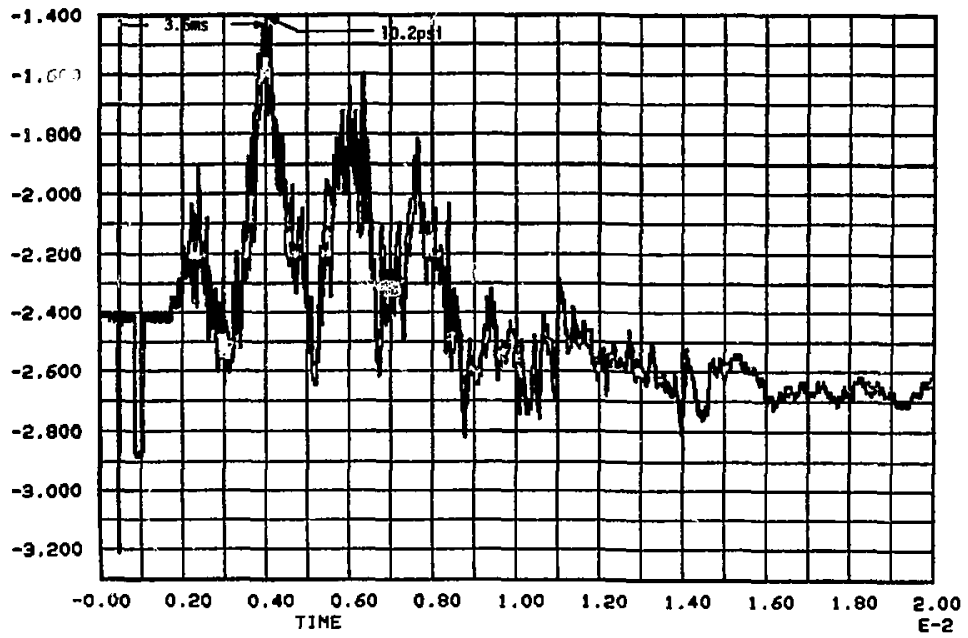

HEAF *2IT POSITION 1 


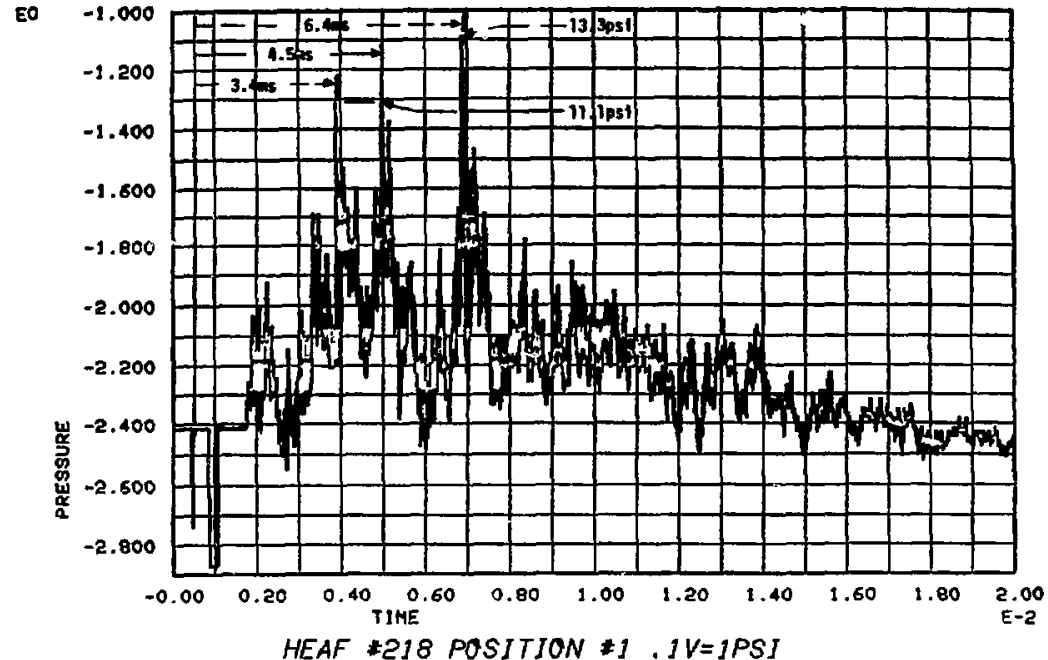

6/23/00 11210A.M.

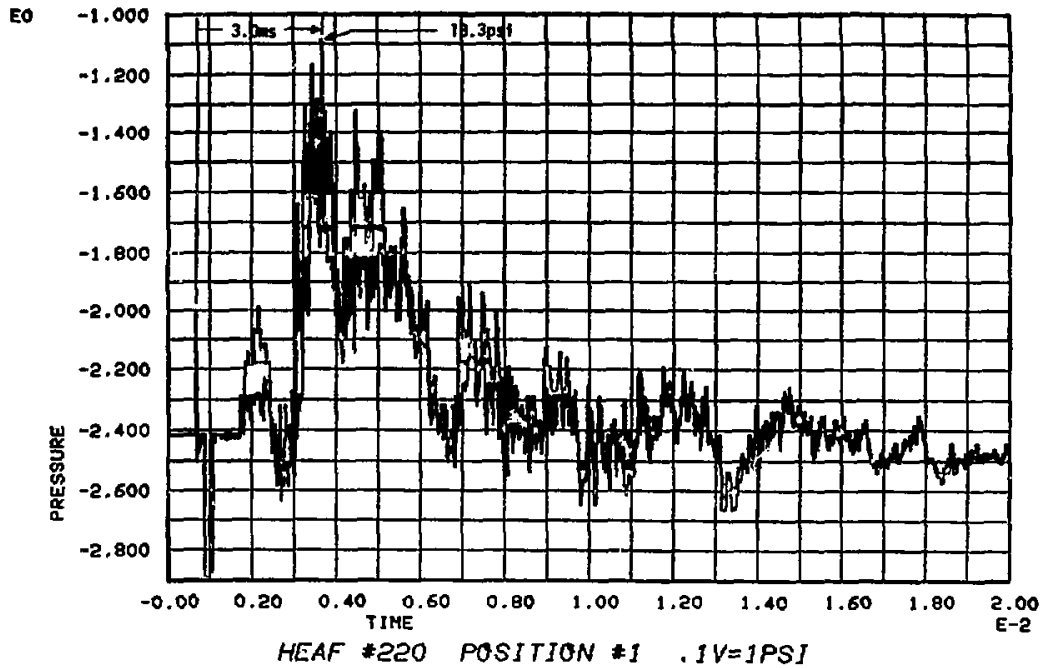


6/29/80 11230A.H.

EO

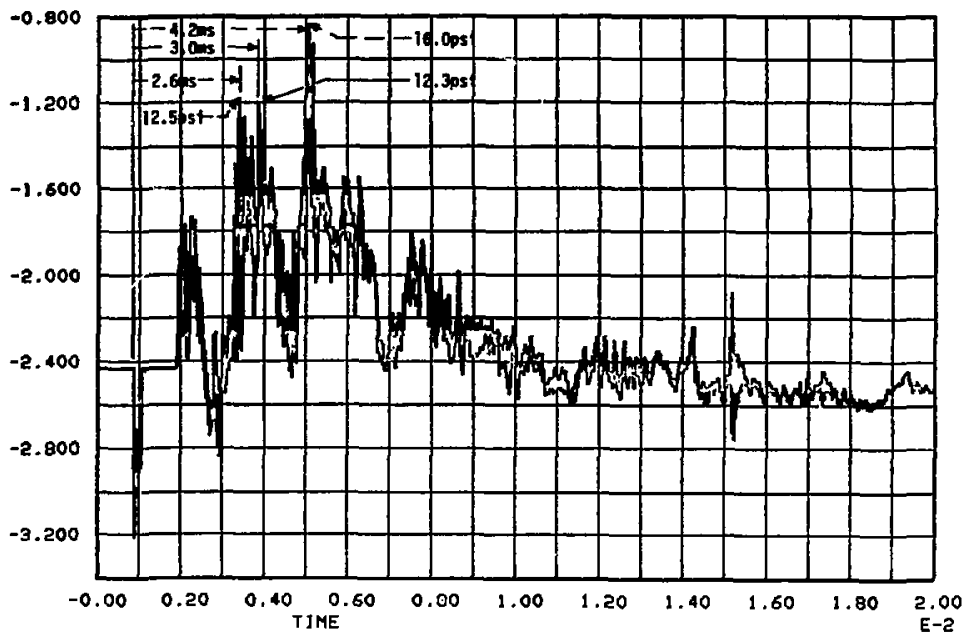

HEAF \#22I POSITION *1. IV=JPSI

$0 / 11 / 80 \quad 13,15$

EO

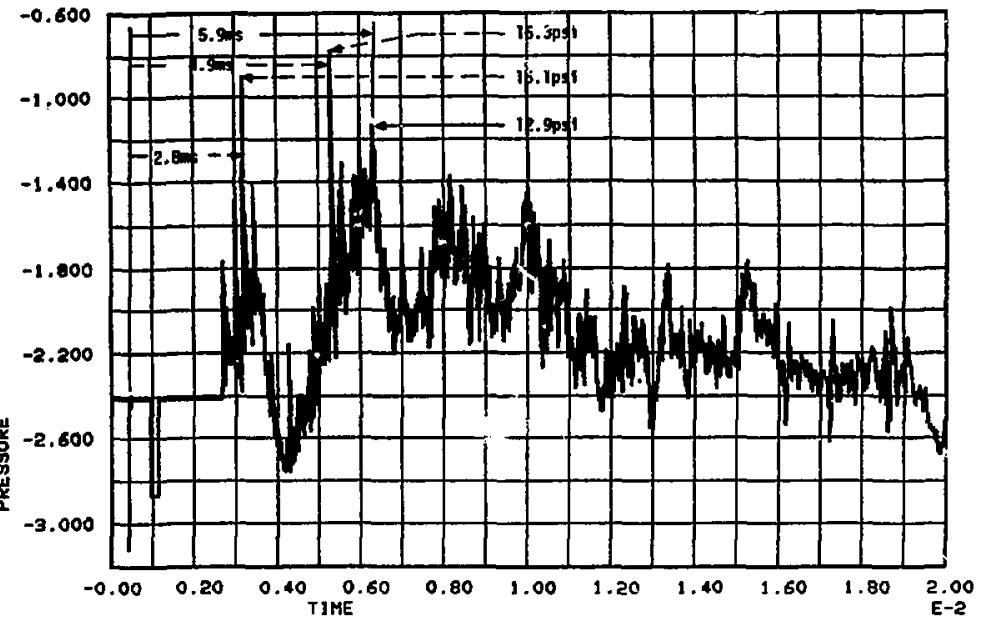

HEAF \#225 POSITION \#I I V=IPSI 


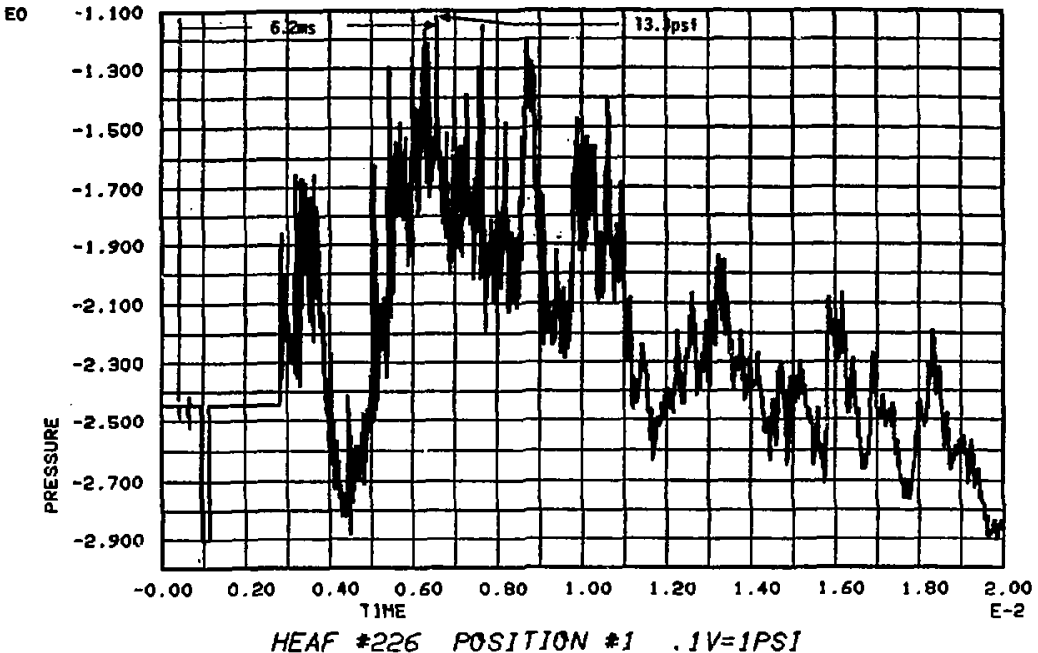

$0 / 11 / 80 \quad 15: 30$

EO

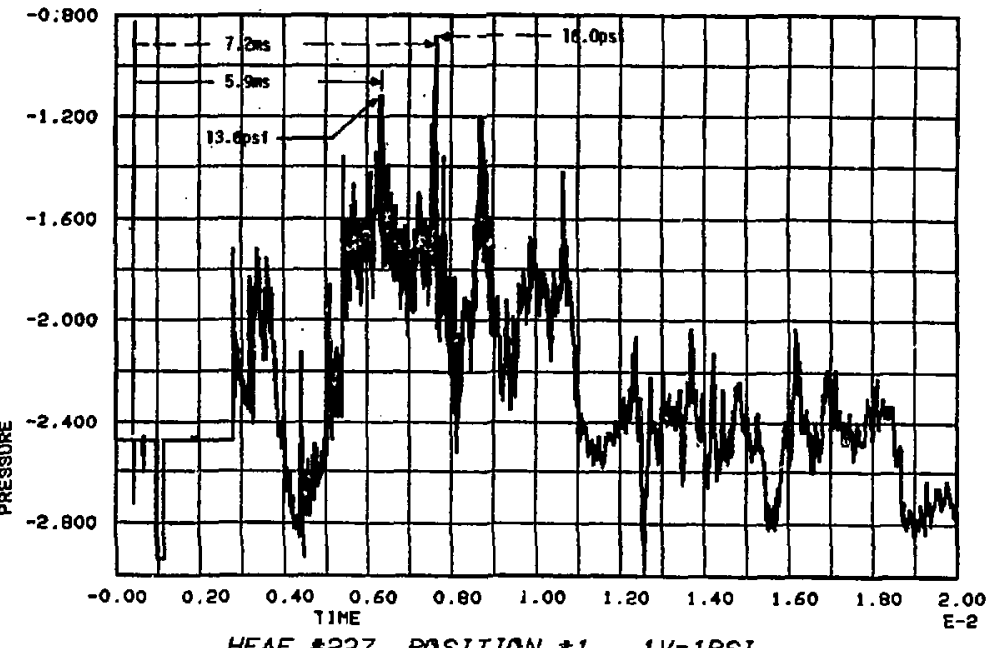

HEAF *227 POSITION $* I$. IV=IPSI 
E0

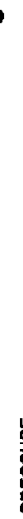

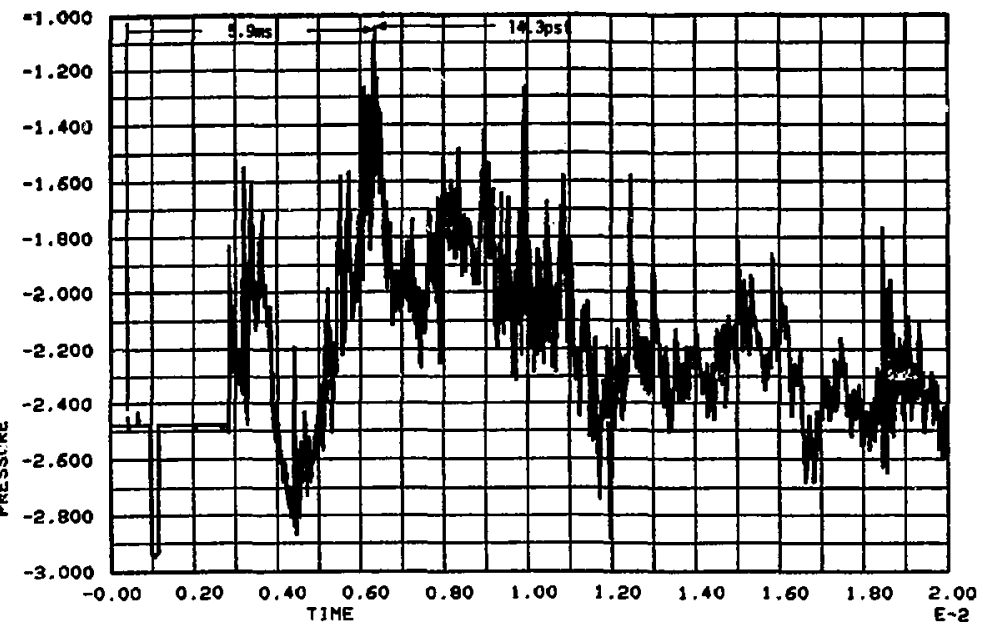

HE,AF $* 228$ POSITION $\# 1$. IV=IPSI

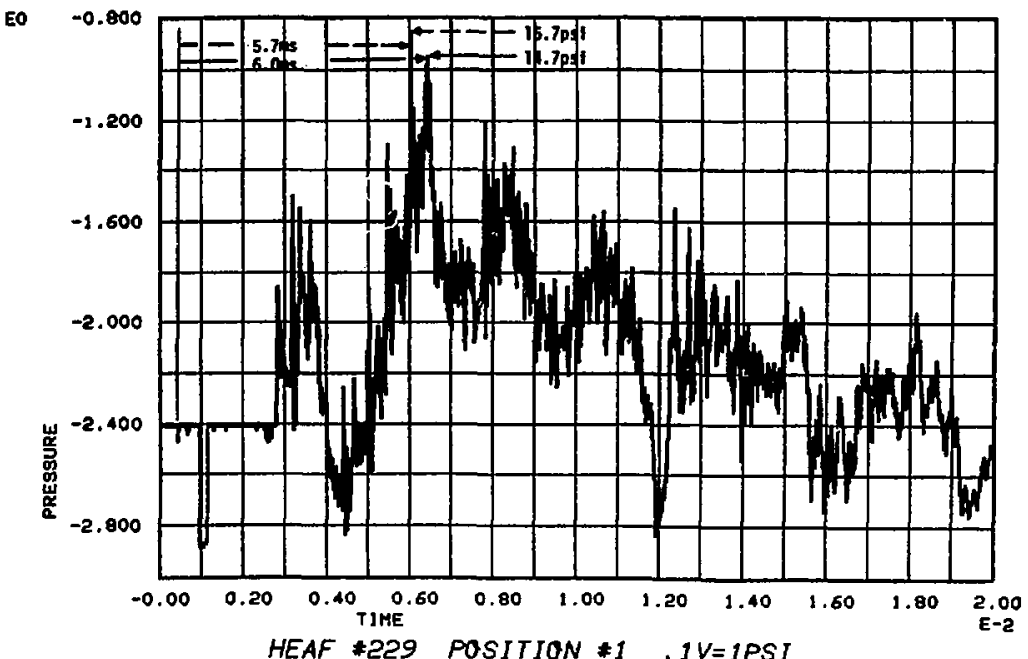


Q/12/80 10,35A.H.

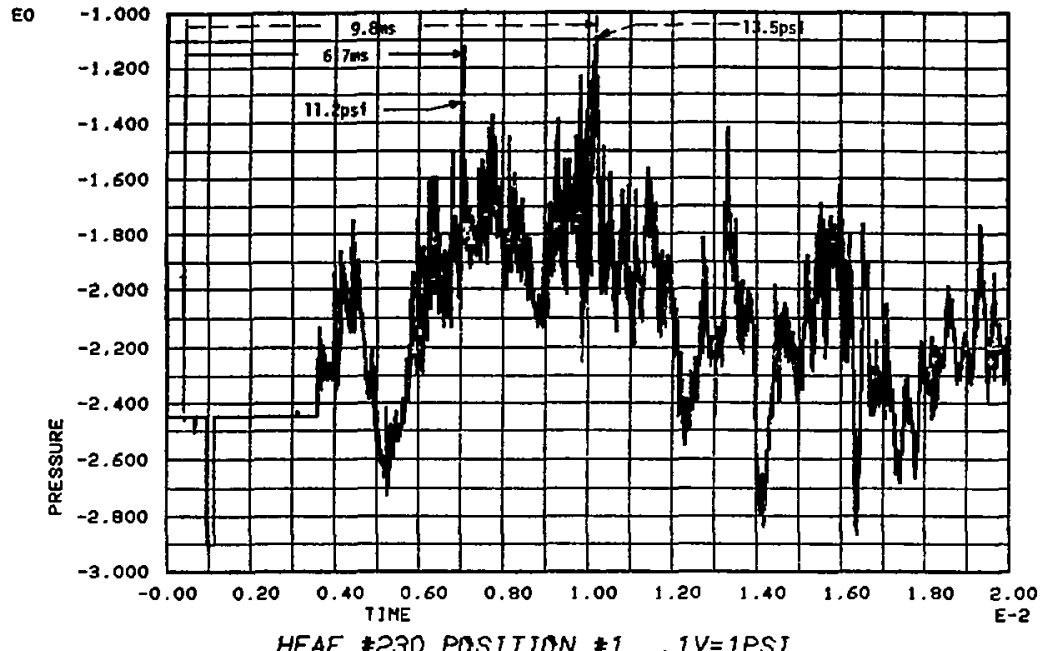

8/12/80 11,05A,H.

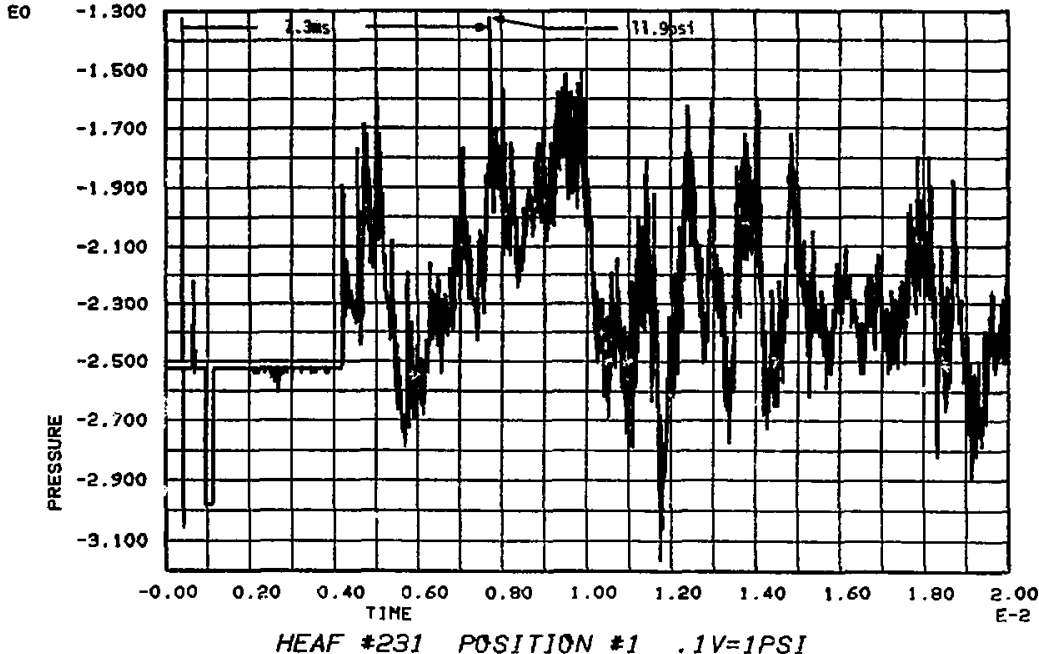


ISdI=AI, I* NOIIISOd EEZ*

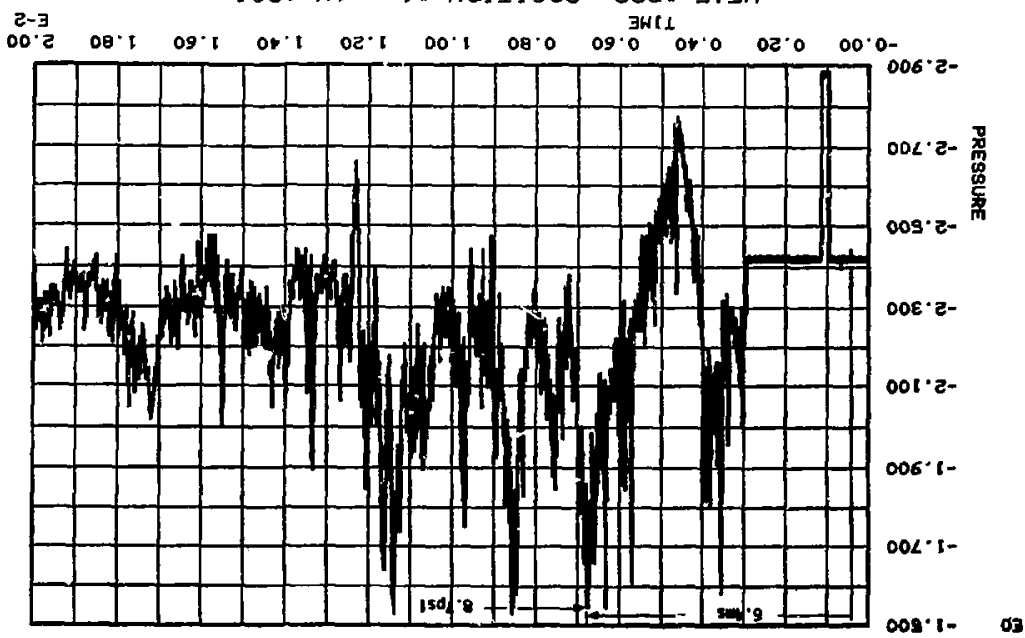

SE'EI OB/EL/8

\section{$I S d I=A I^{\prime} \quad[*$ NOIIISOd ZEZः $J \forall \exists H$}

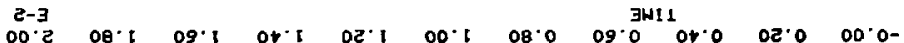

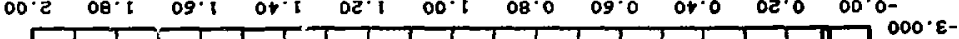

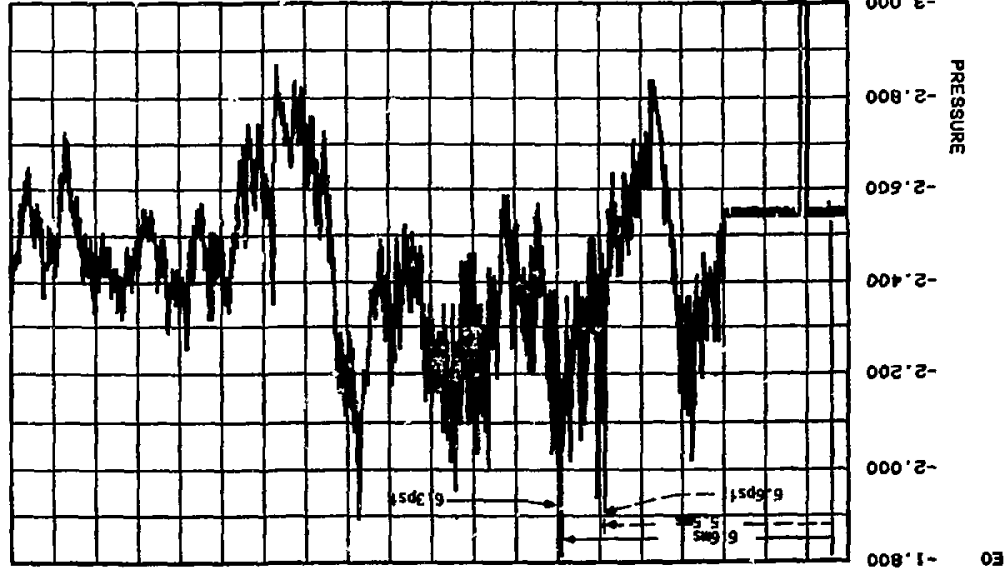



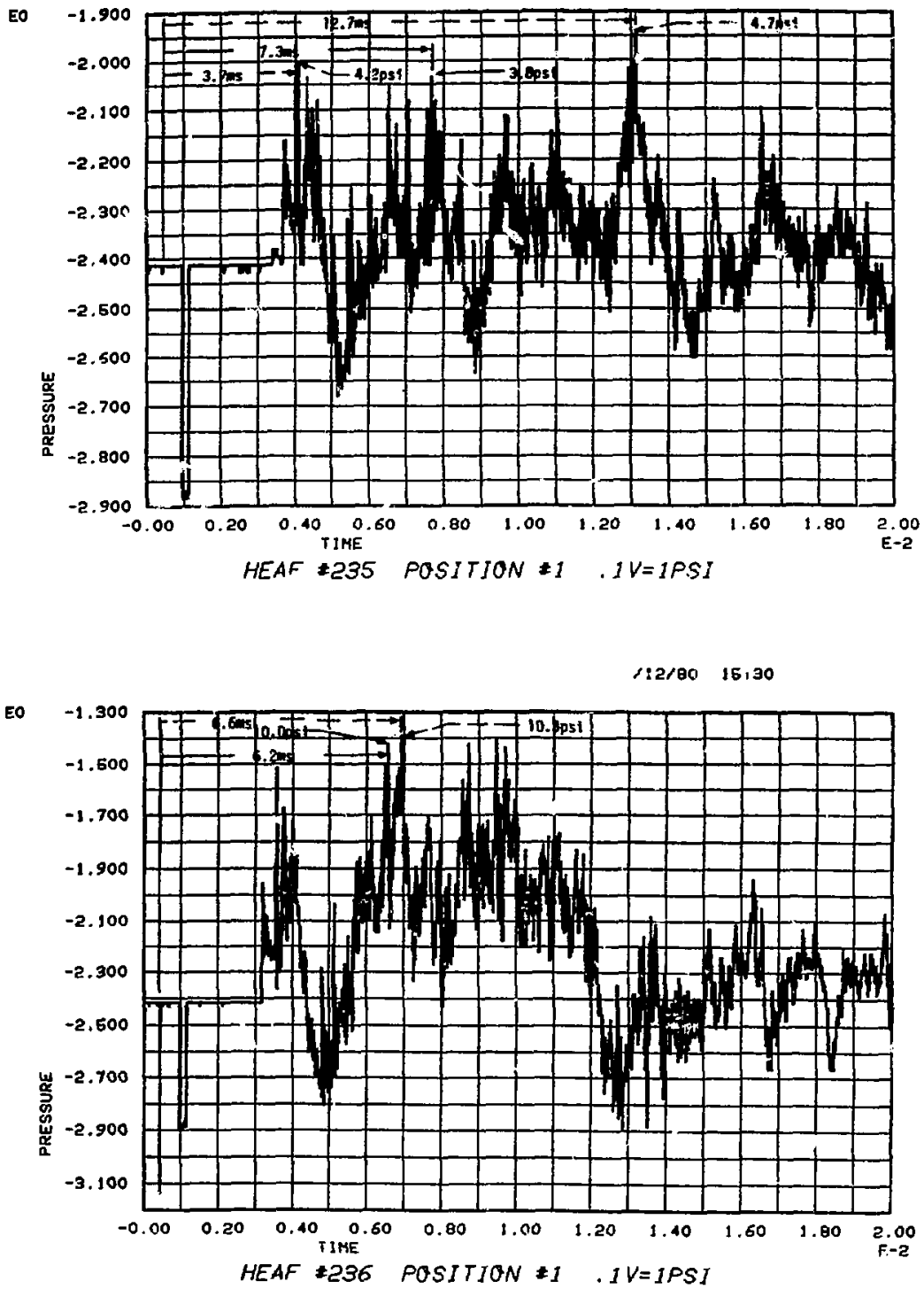

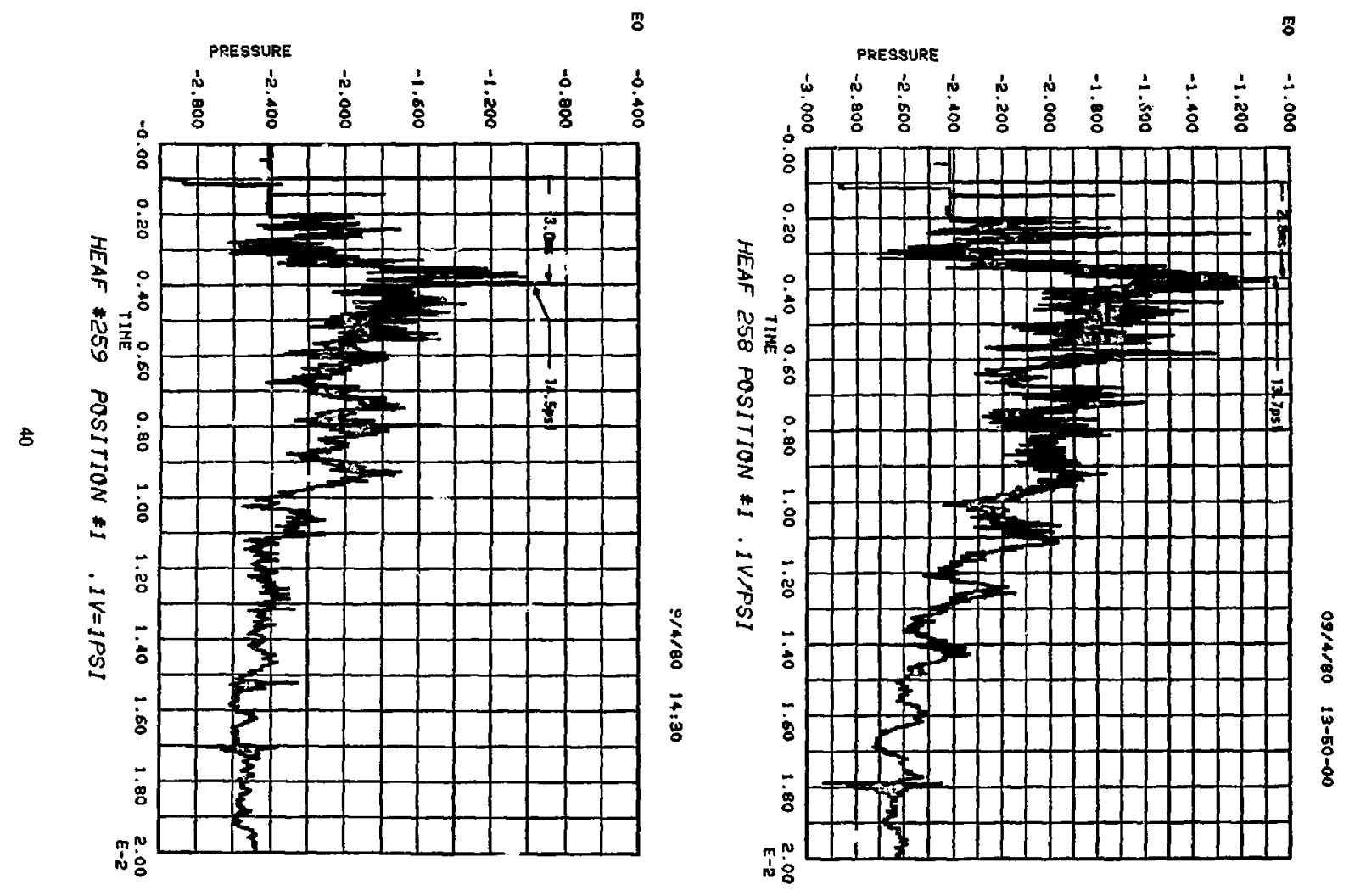
EO

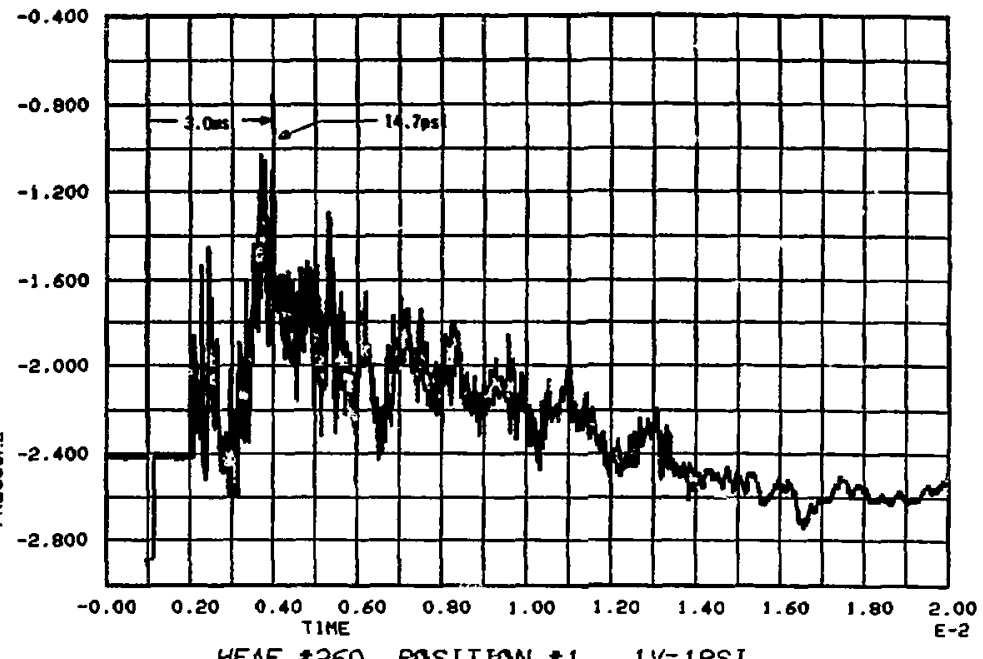

HEAF $* 260$ POSITION $I .1 V=J P S I$

E0

$$
\begin{aligned}
& -0.400 \\
& -0.800
\end{aligned}
$$

$-1.200$

$-1.600$

$-2.000$

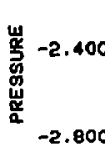
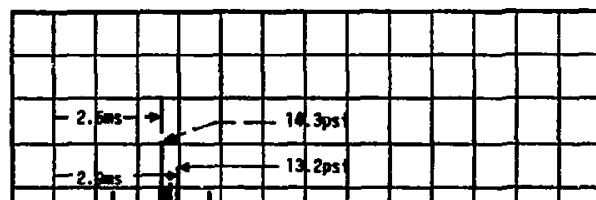

$15: 45$ 


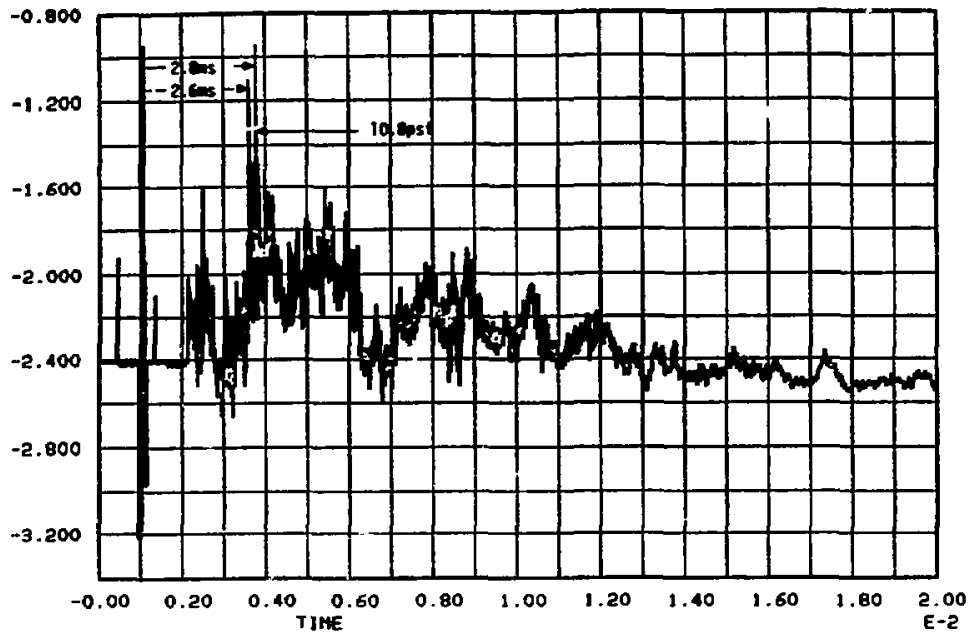

HEAF *262 POSITION $I . I V=I P S I$

9/5/80 10:30A.H.

EO

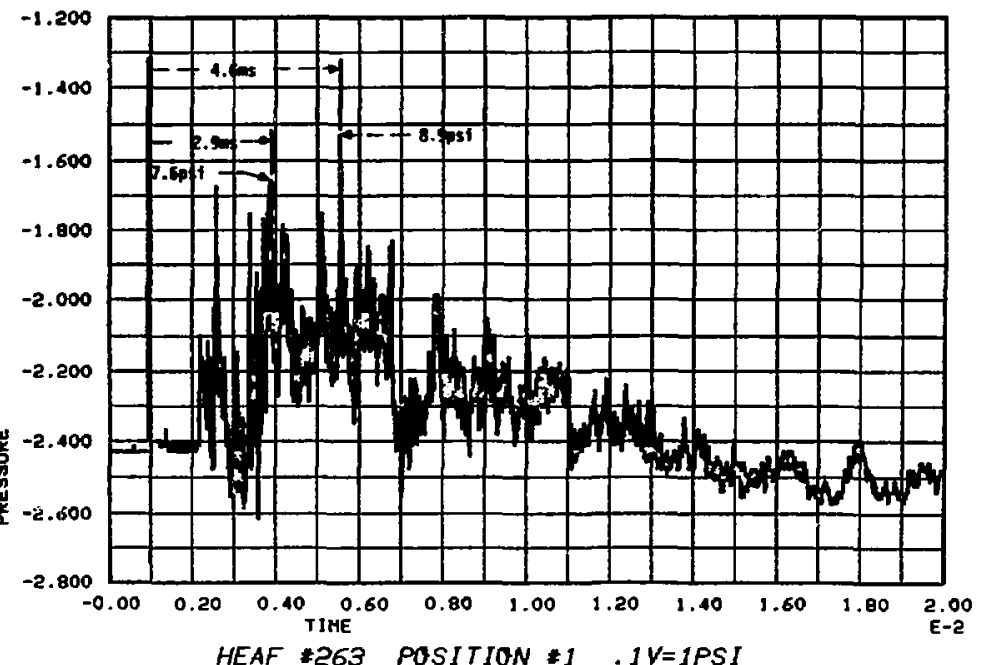


9/5/20 11;00A.M.

EO

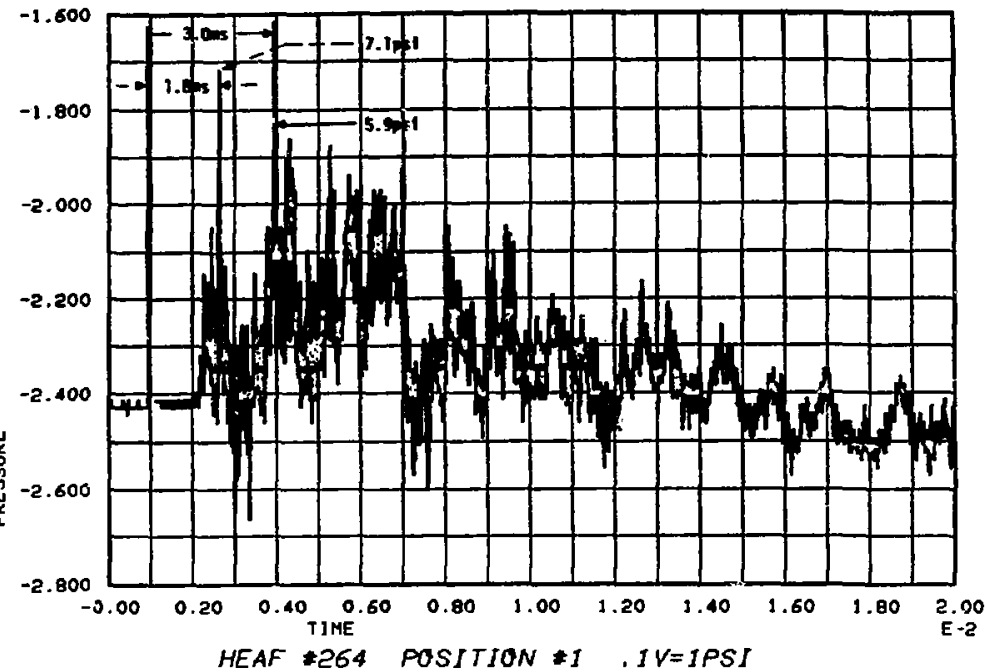

9/5/80 11,20A.M.

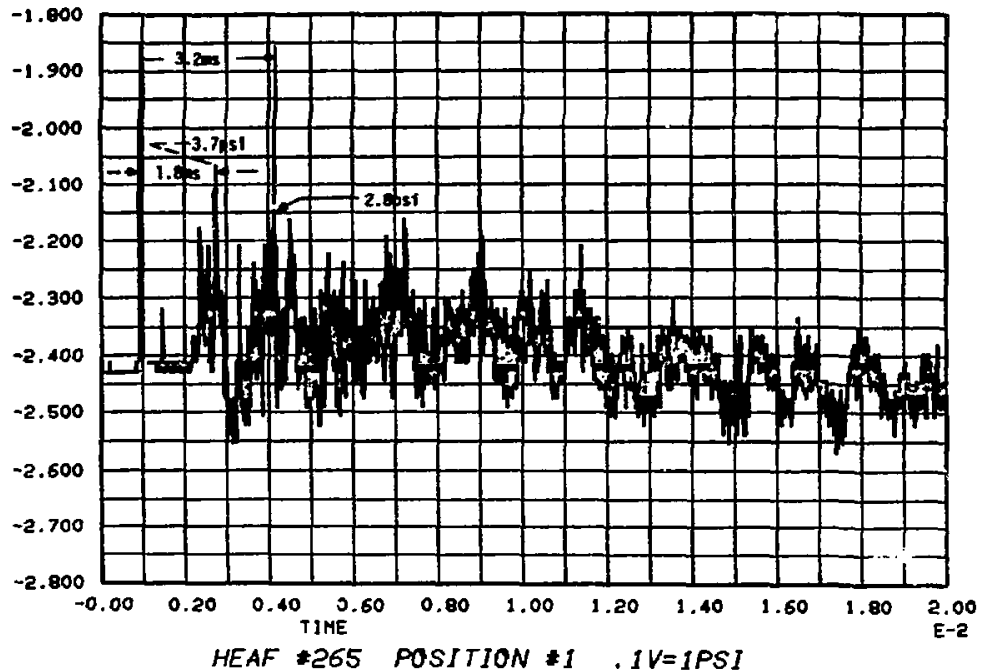


EO

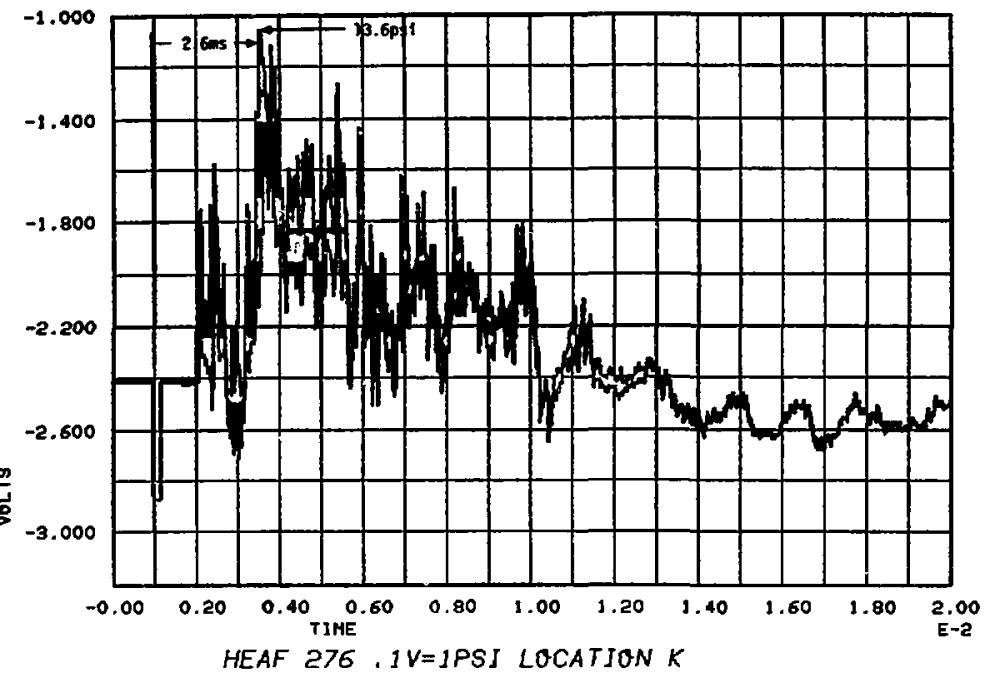

$10 / 09 / 80 \quad 16,10$

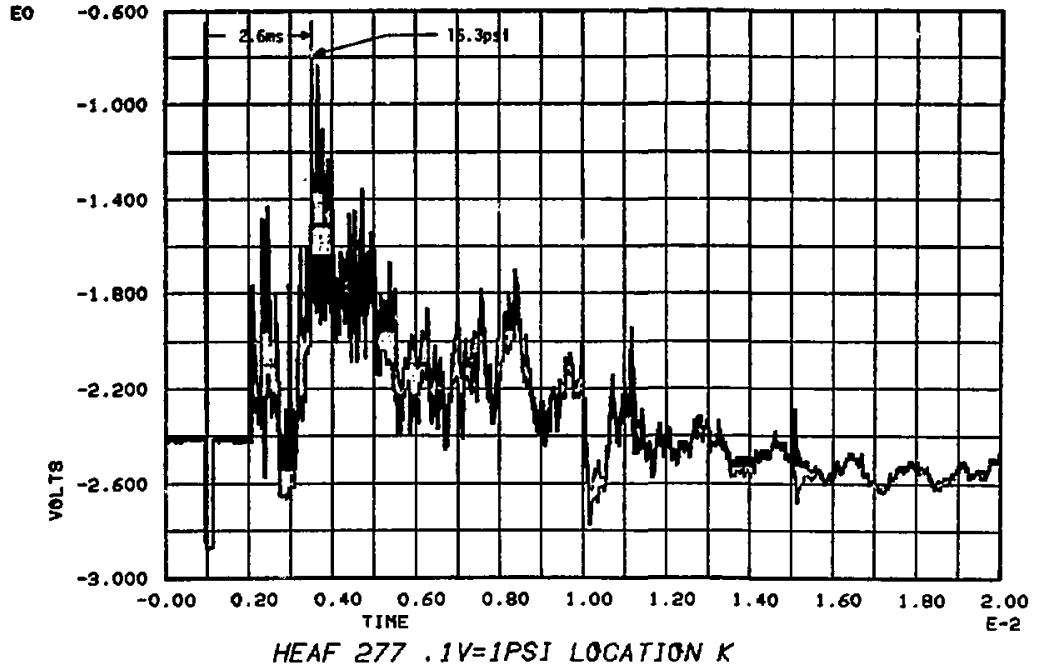




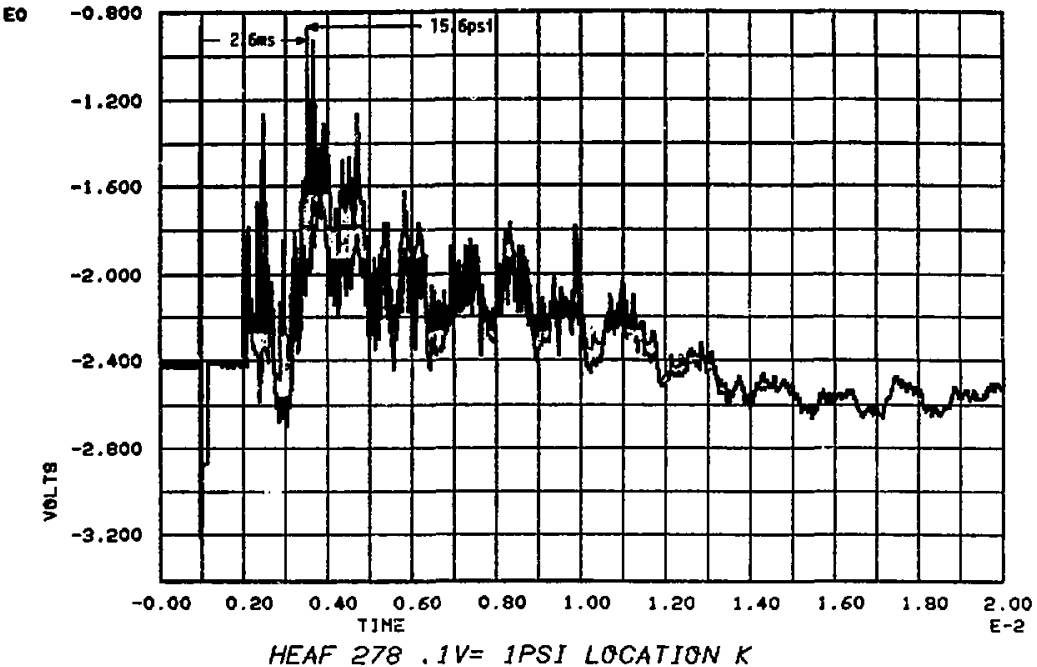

$10 / 10 / 8011: 15$

EO

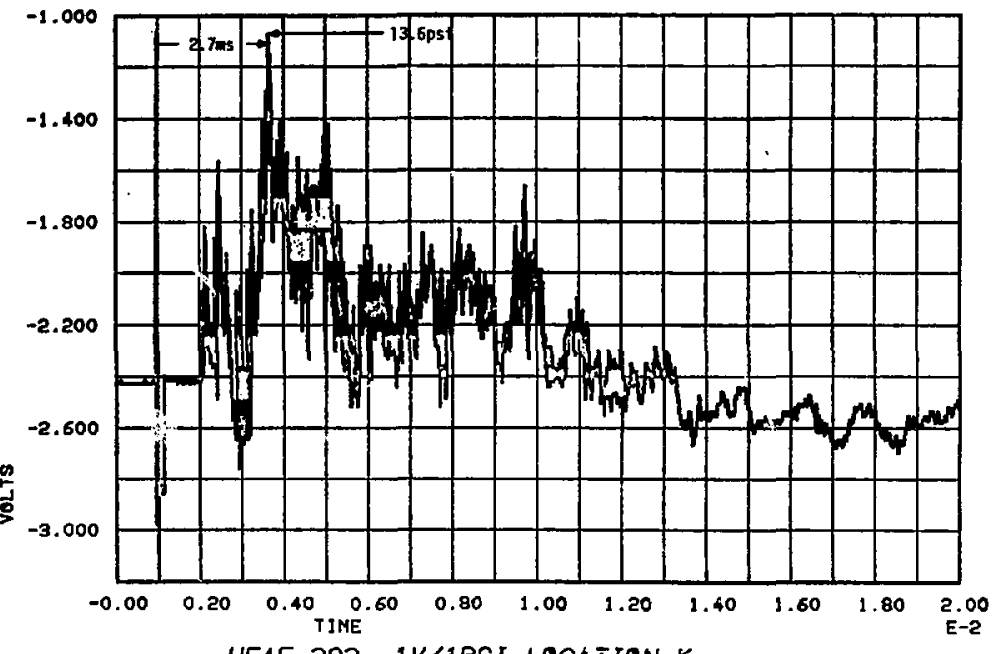

HEAF 282 . IV/IPSI LOCATION K 


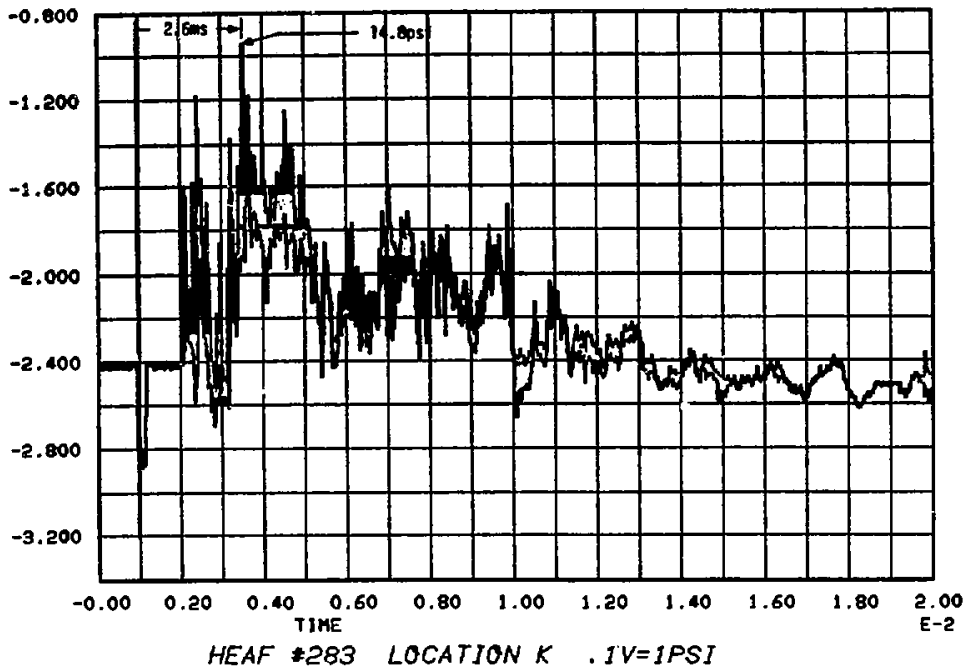

$10 / 13 / 80 \quad 08,54$

EO

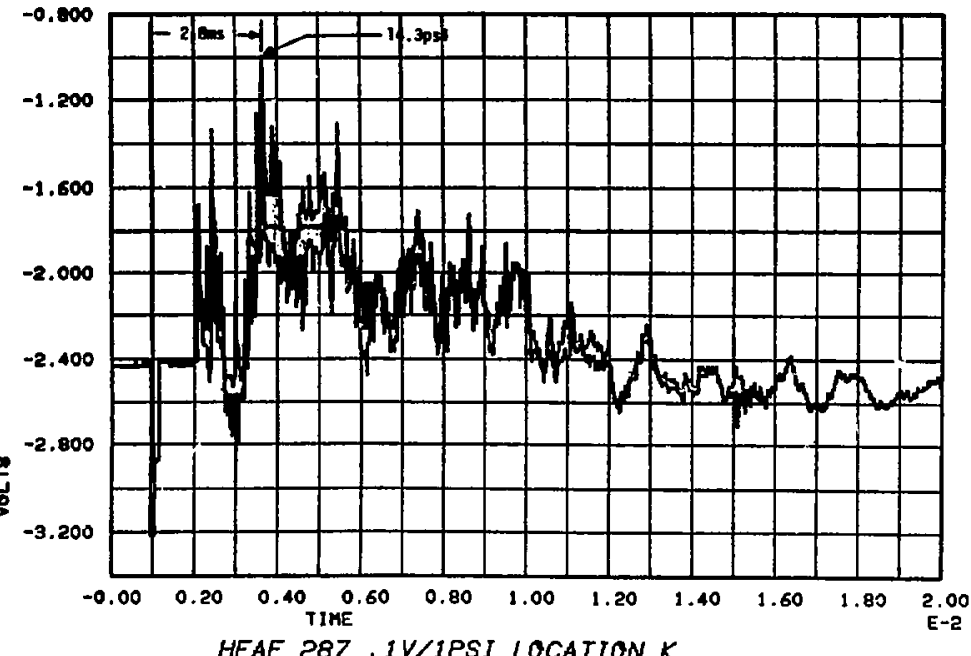




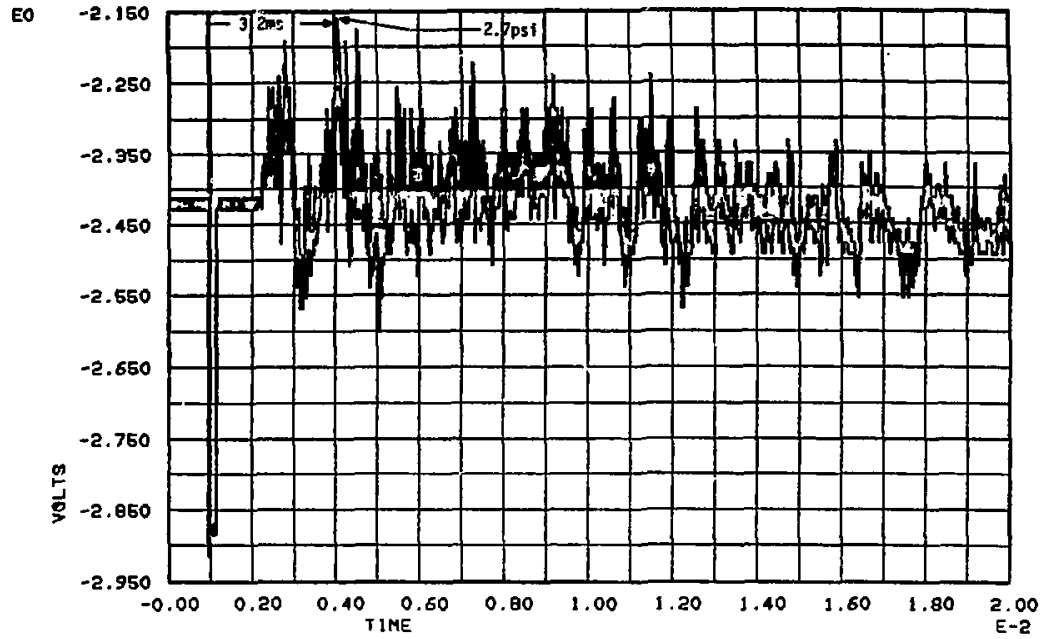

HEAF 288. IV/IPSI LOCATION K . GGRAMS

$10 / 13 / 80 \quad 09,35$

EO

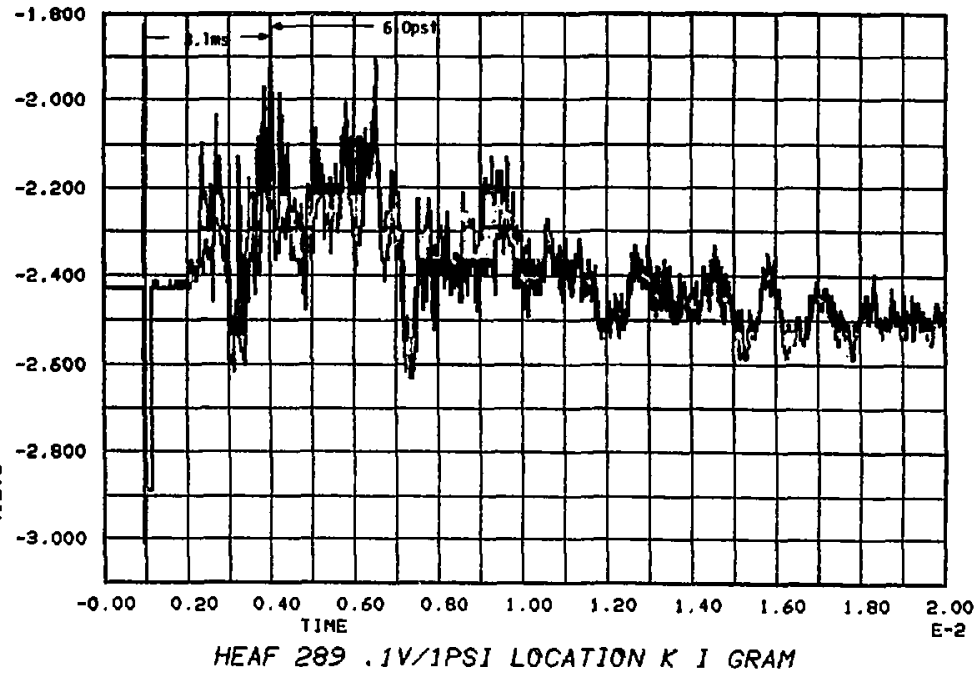




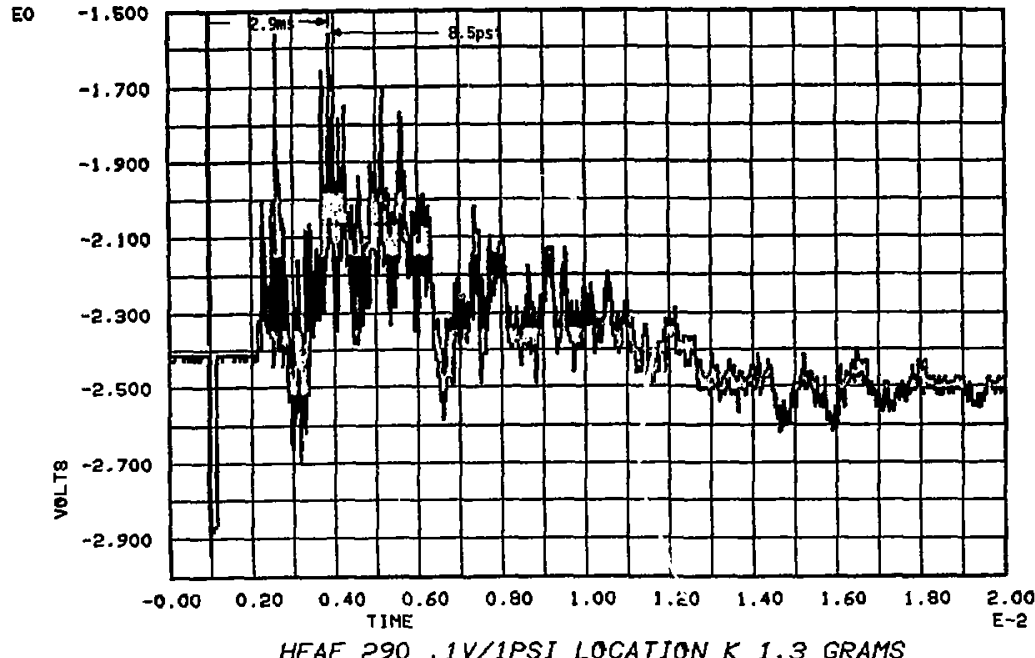

$10 / 13 / 8010,46$

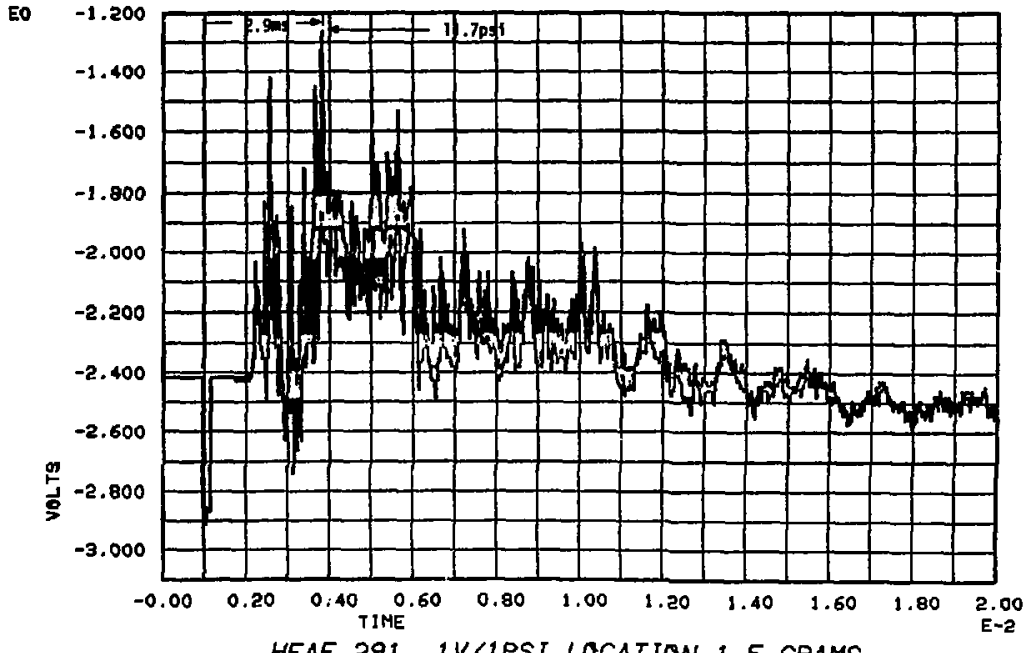

HEAF 291.1V/IPSI LOCATION 1.5 GRAMS 


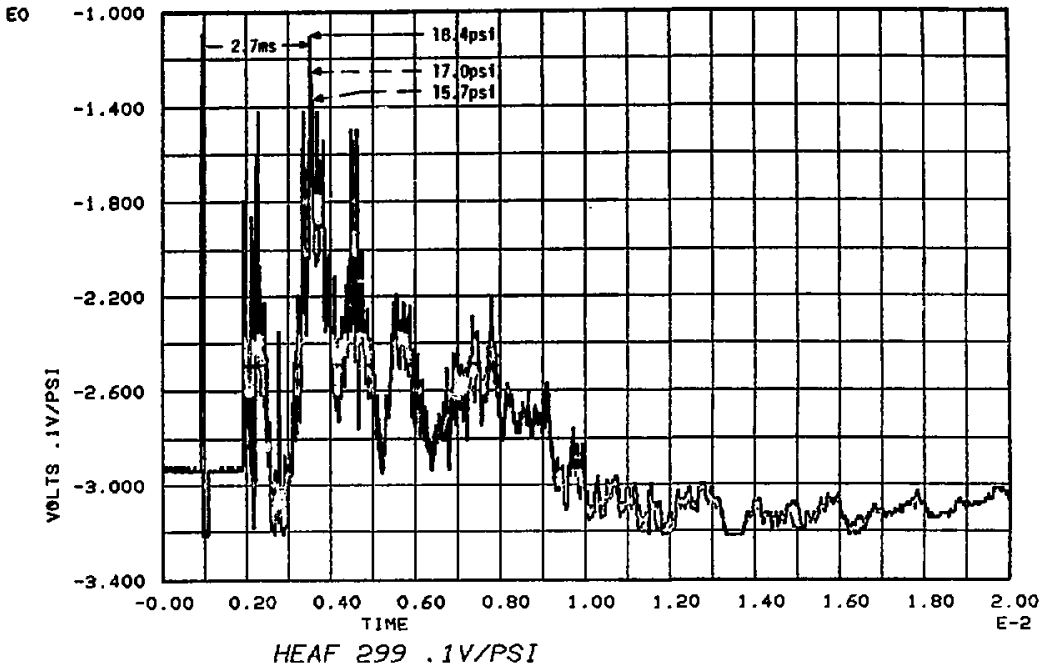

$11 / 07 / 8009,00$

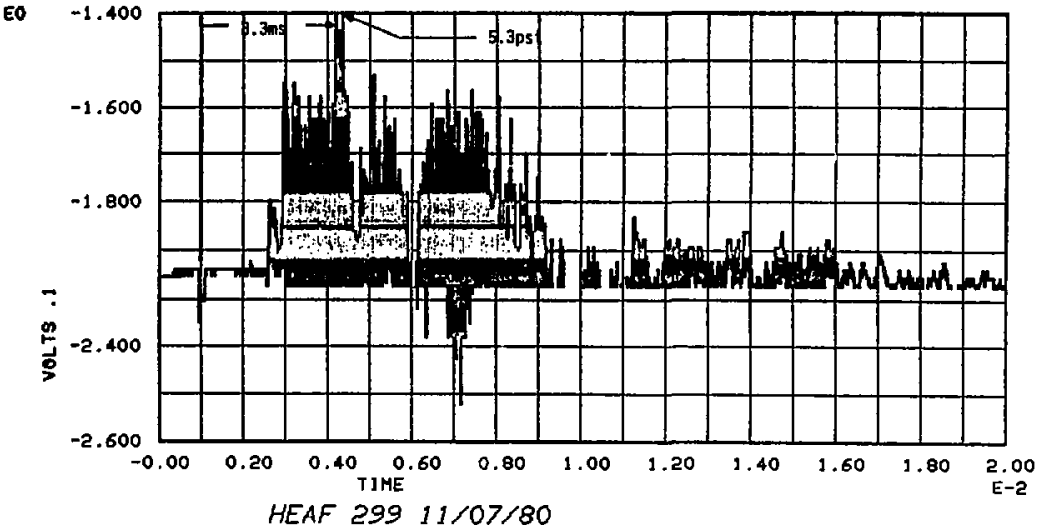




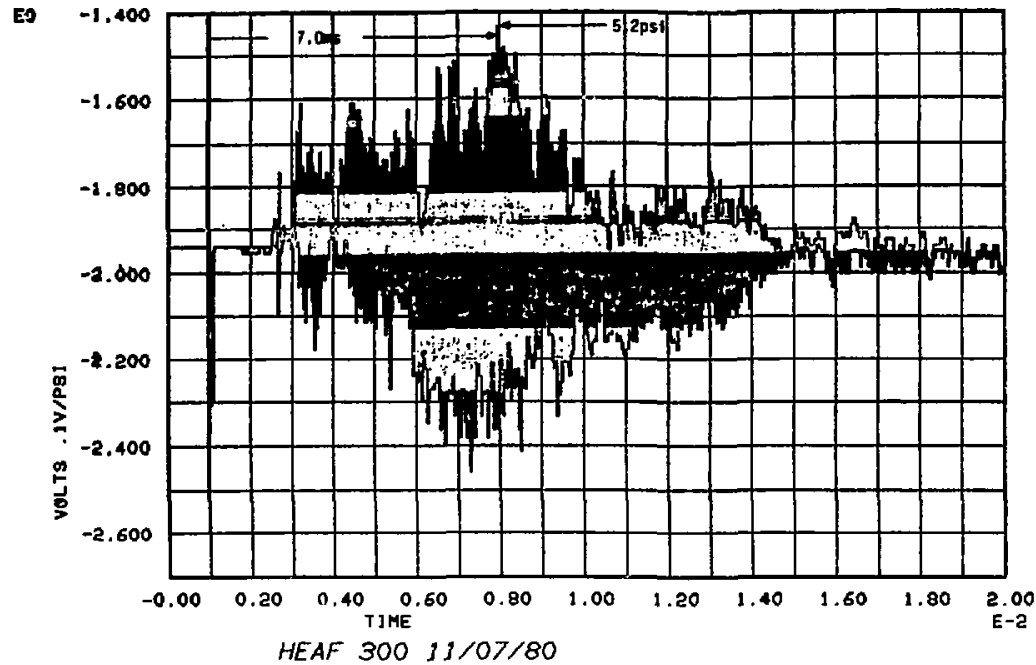

, /07/80 09,35

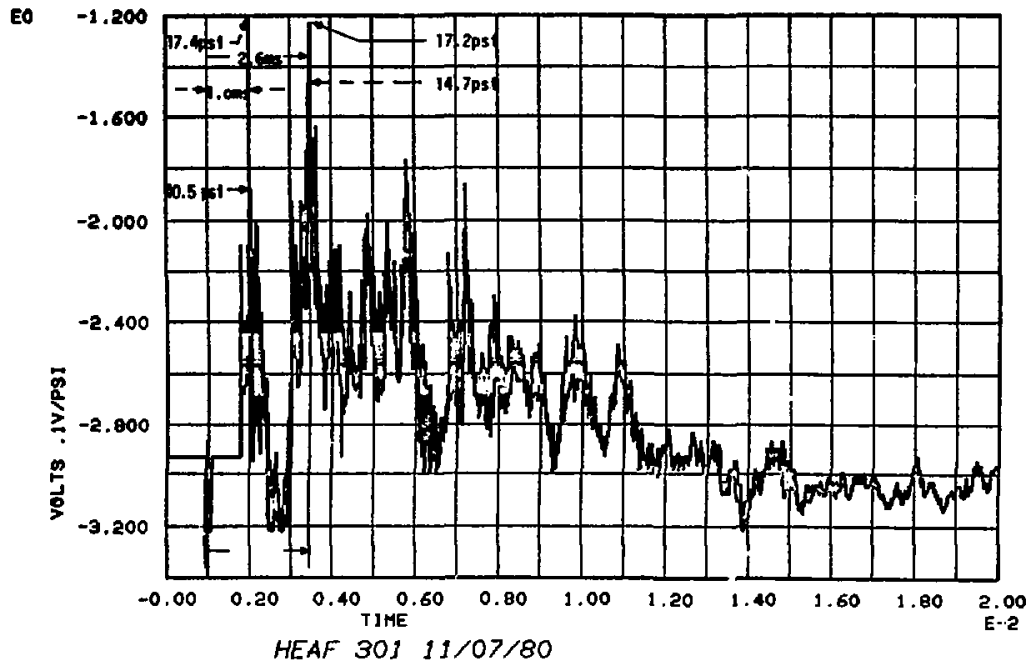


EO

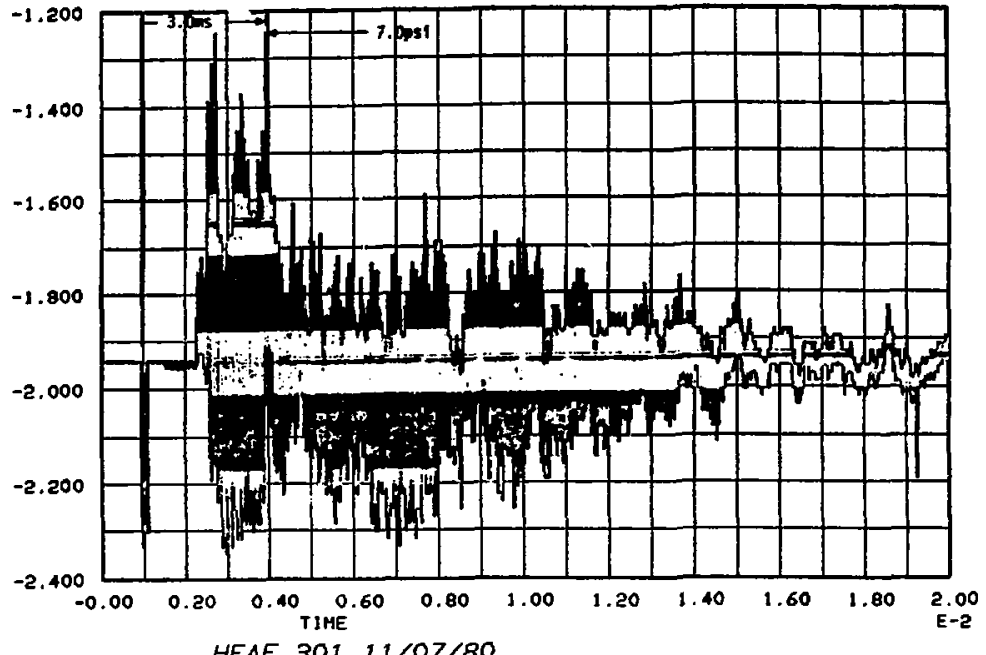

HEAF $30111 / 07 / 80$

$11 / 07 / 8010,40$

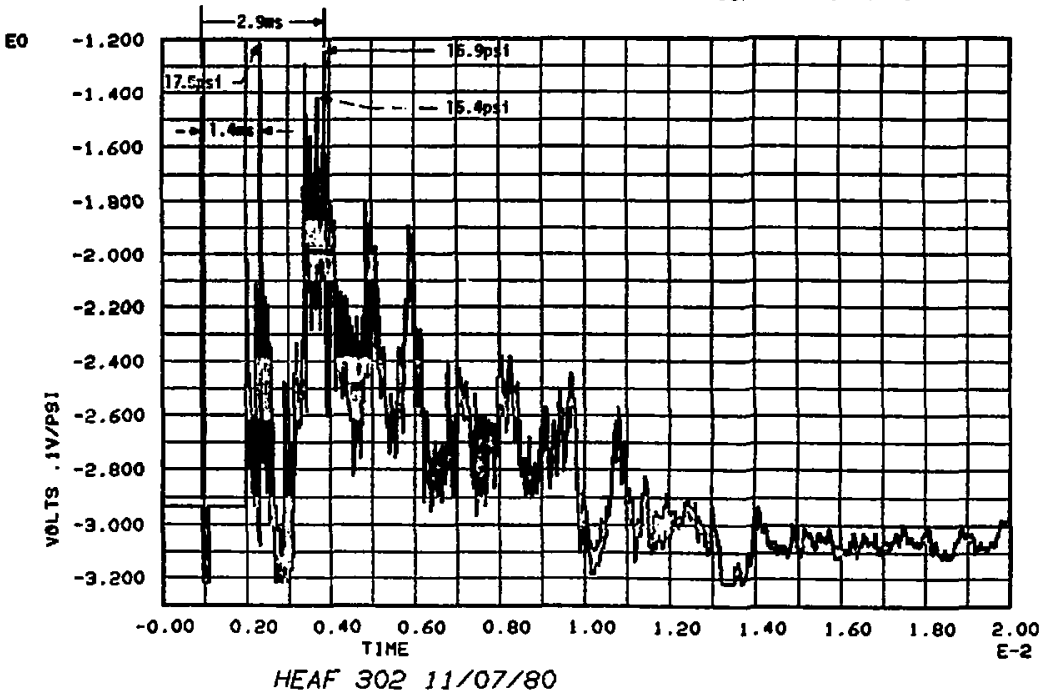


EO

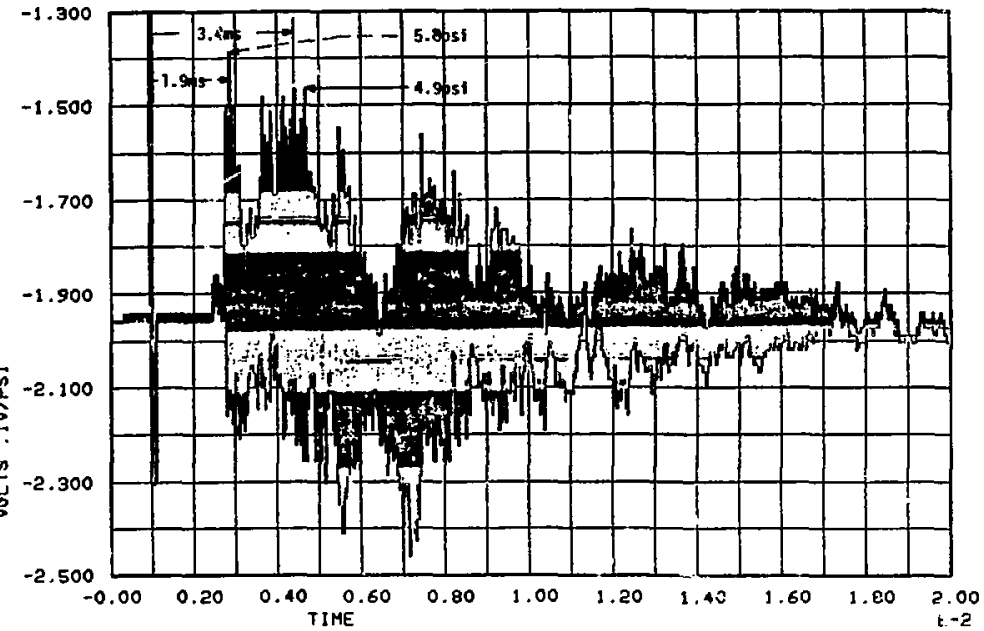

HEAF $30211 / 07 / 80$

EO

$-1.700$

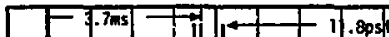

$-1.900$

$-2.100$

$-2.300$

$-2.500$

2.800

$\begin{array}{ll}\dot{0}^{\circ} & -2.700 \\ 2 & -2.900 \\ 0 & \\ \frac{5}{5} & -3.100\end{array}$

$-3.300$
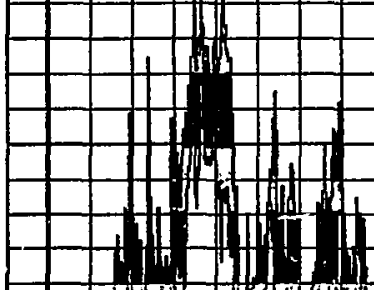


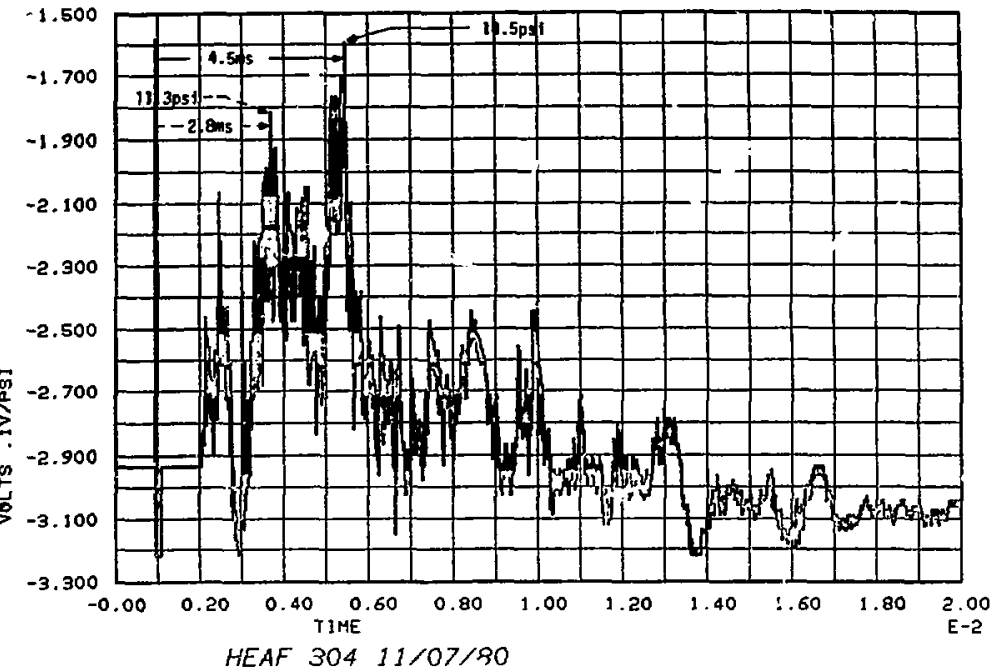

$11 / 07 / 80,11,30$

EO

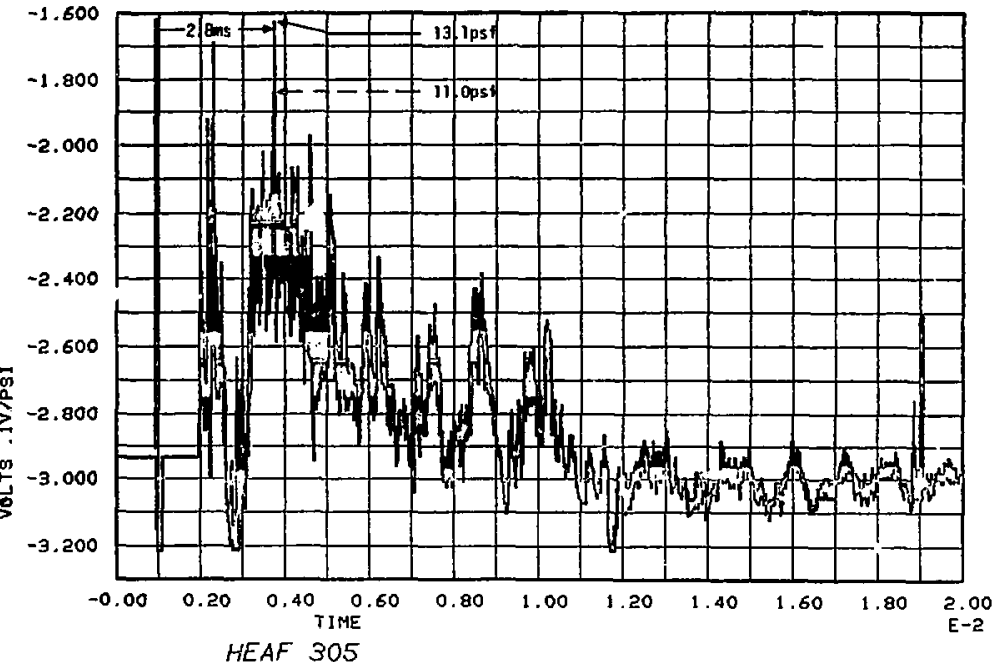



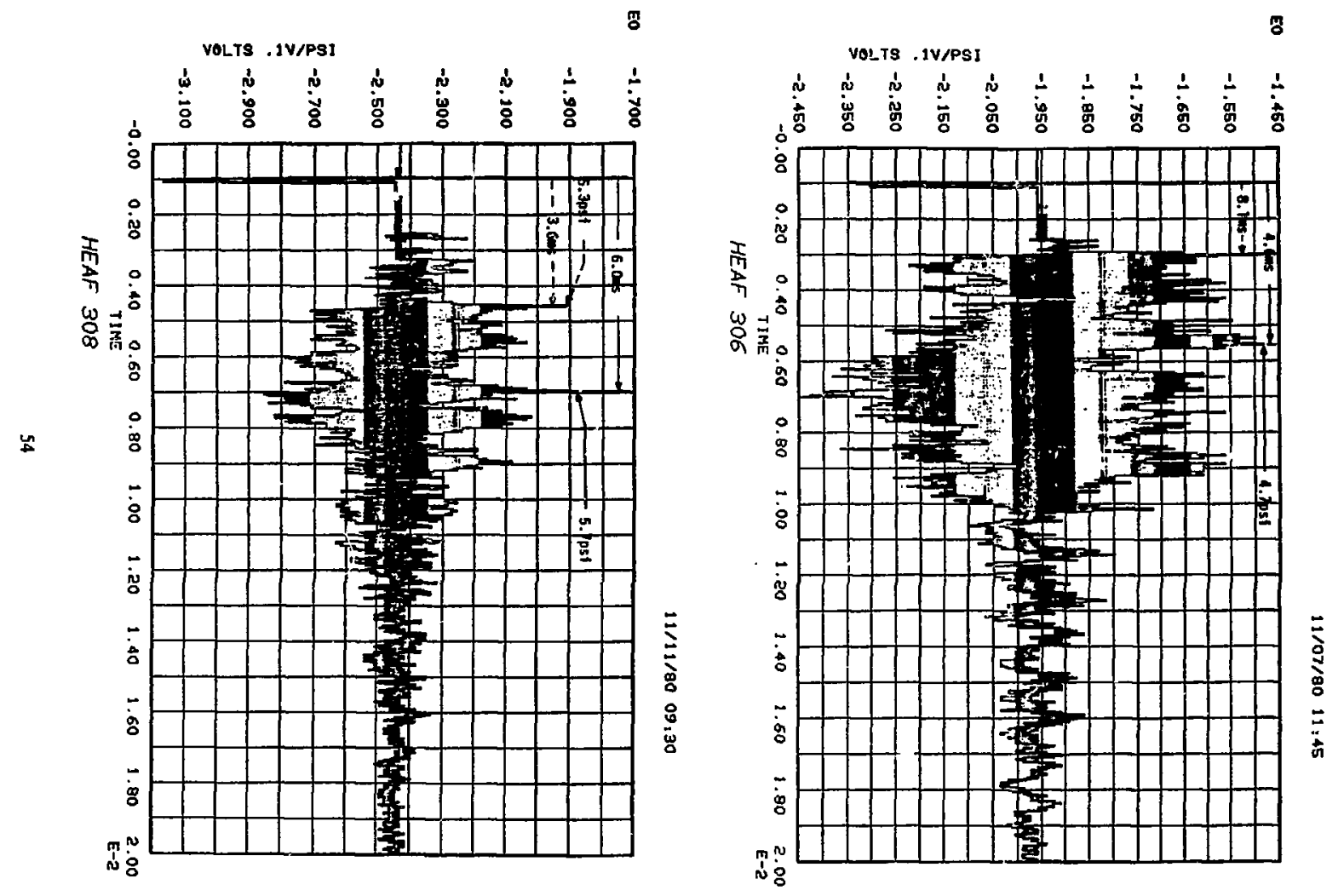

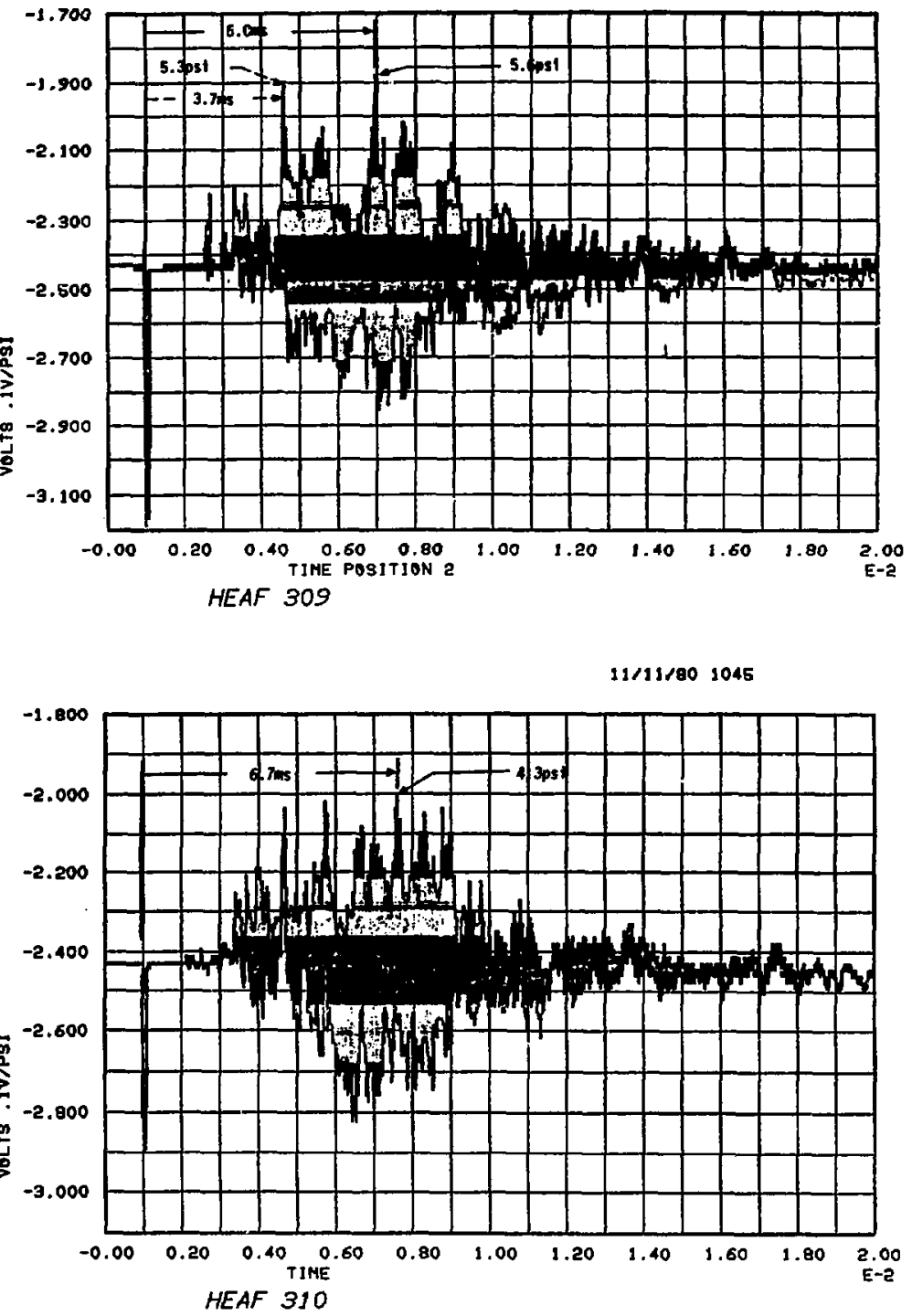


$$
\varepsilon I E \exists H \exists H
$$

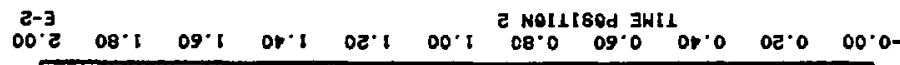

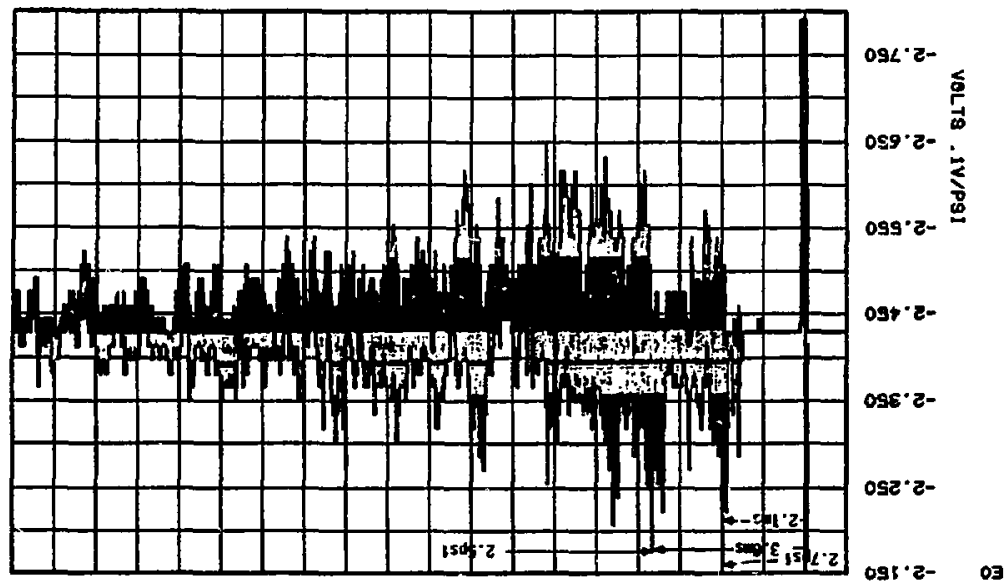

9t El 0o/th/t

I $[\varepsilon \quad \forall \forall H$

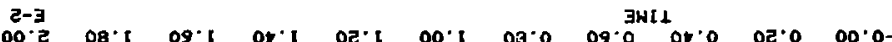

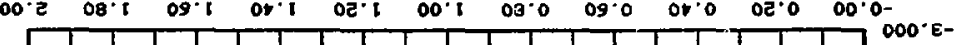

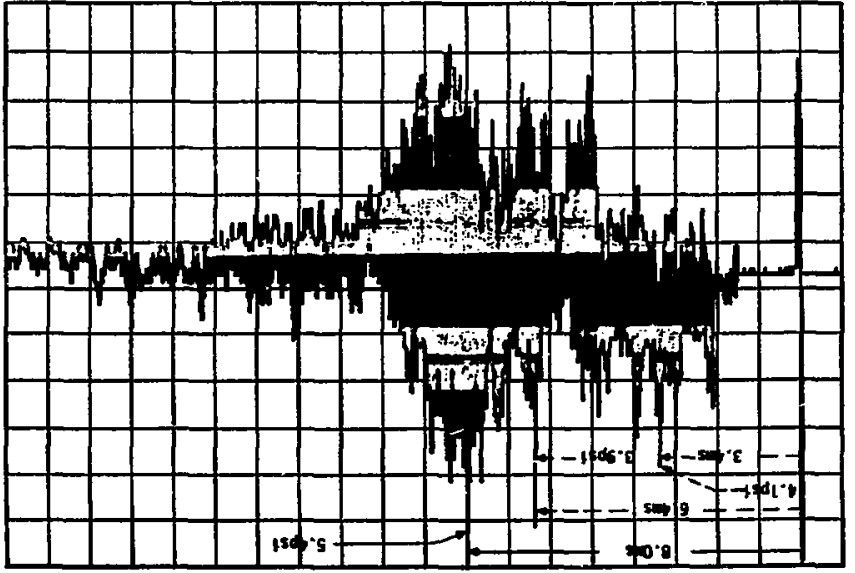

$000 \cdot z-\frac{5}{\frac{5}{6}}$

$\cot 2-$

$002 \cdot 2-$

$000^{\prime 2}-$

$000^{\circ} 1-\quad 03$ 
50

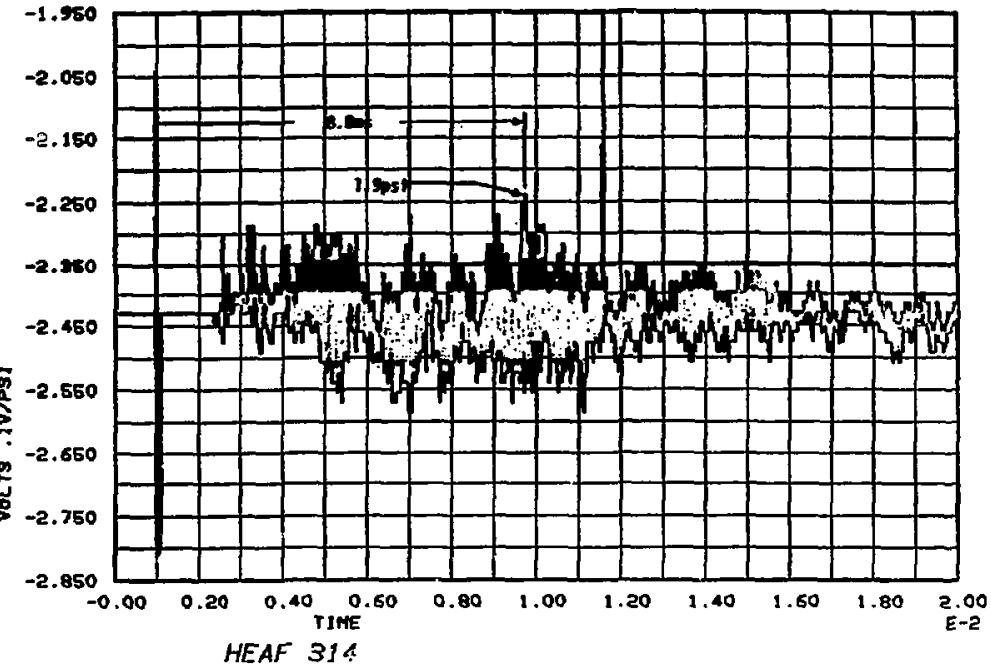

$12 / 22 / 80 \quad 15,24,00$

EO

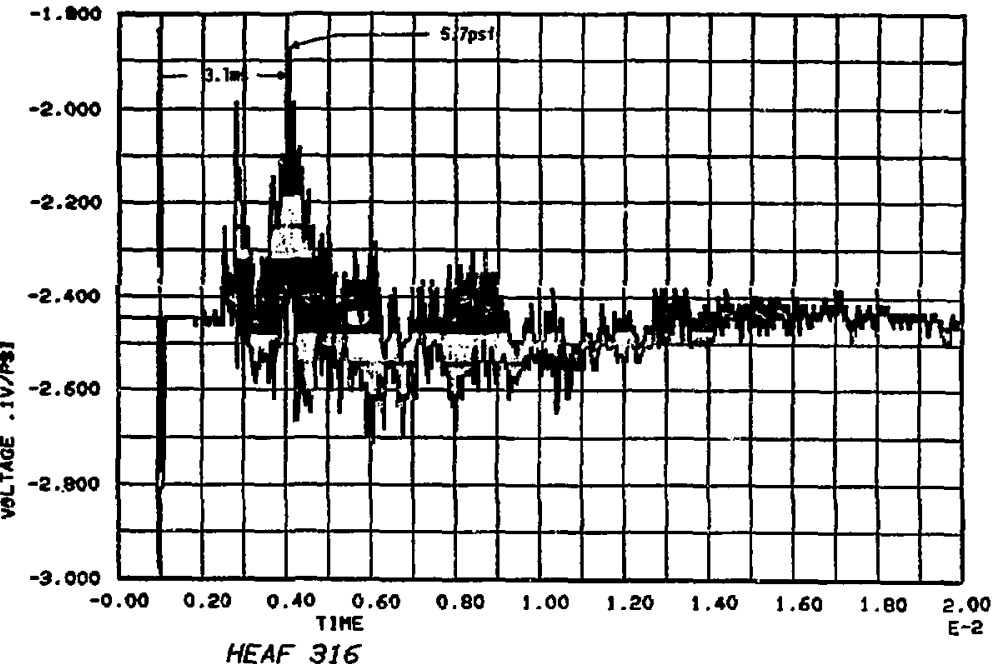


00

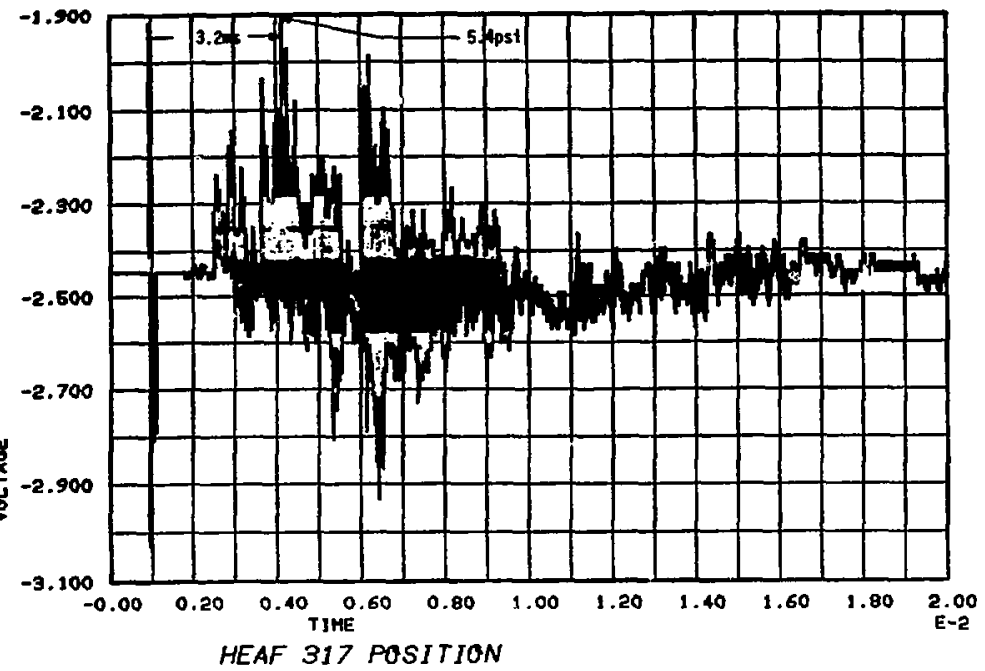

$92 / 22 / 8016,25$

EO

$-1.900$

$-2.000$

$-2.100$

$-2.200$

$-2.300$

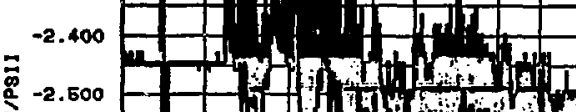
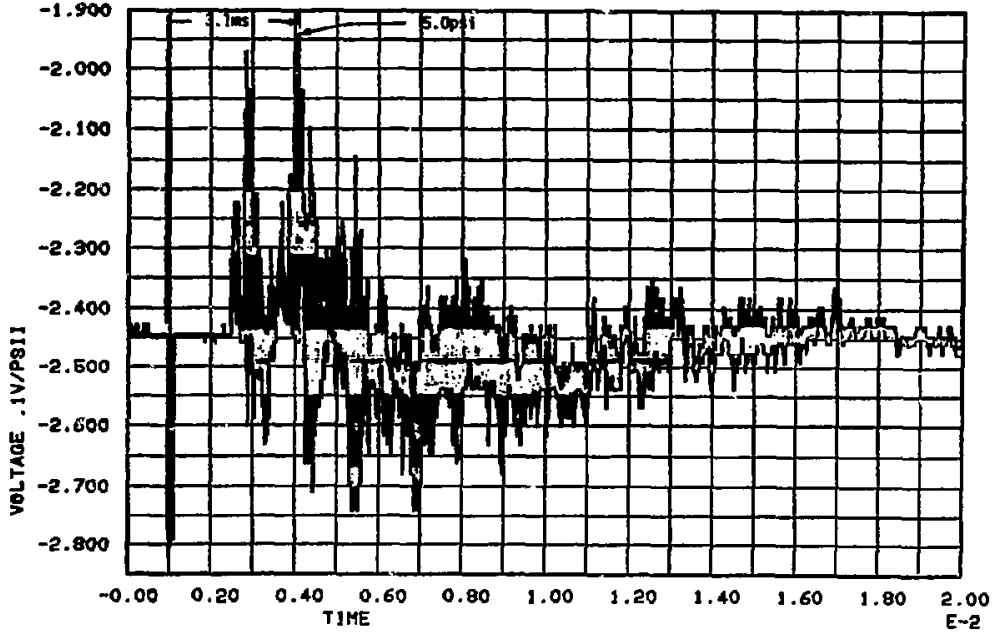

HEAF 318 POSITION 


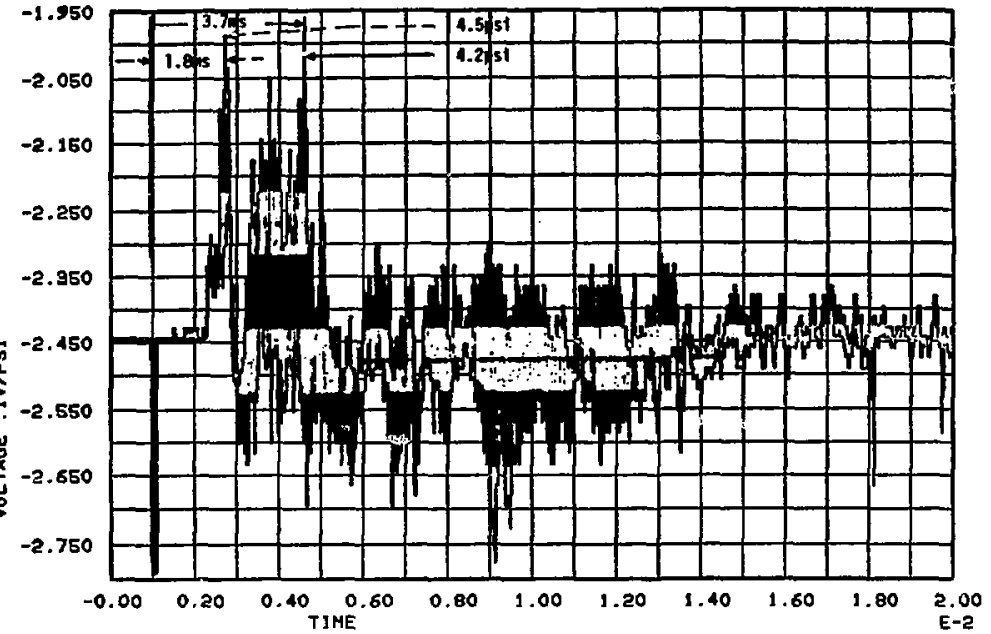

MEAF 319 POSITION 3

$12 / 23 / 8008,55,00$

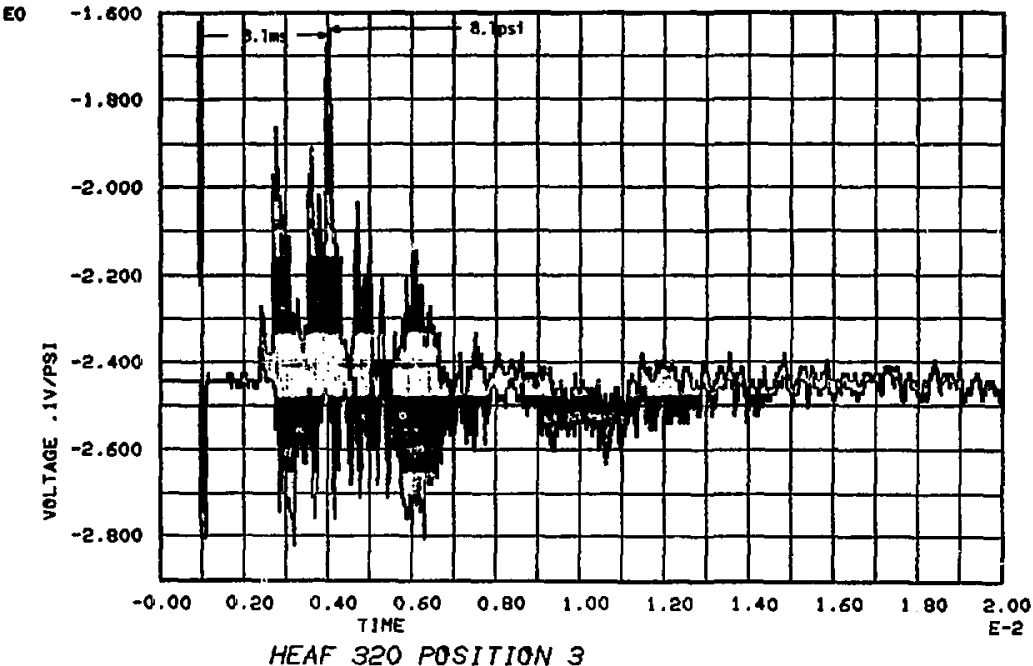




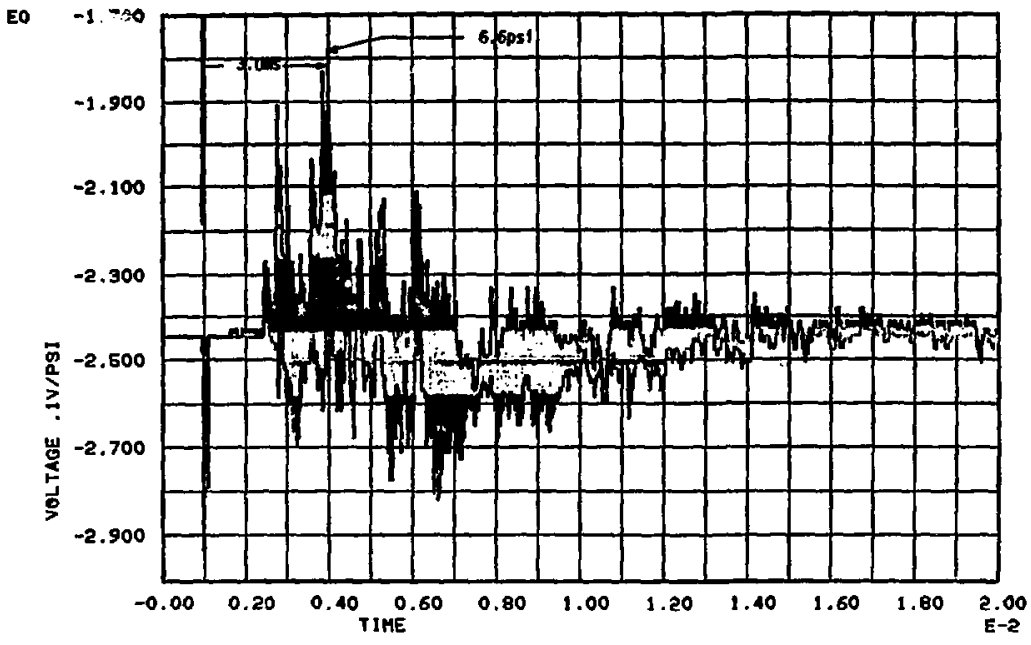

HEAF 321 POSITJON 3

$12 / 29 / 80 \quad 09,69,00$

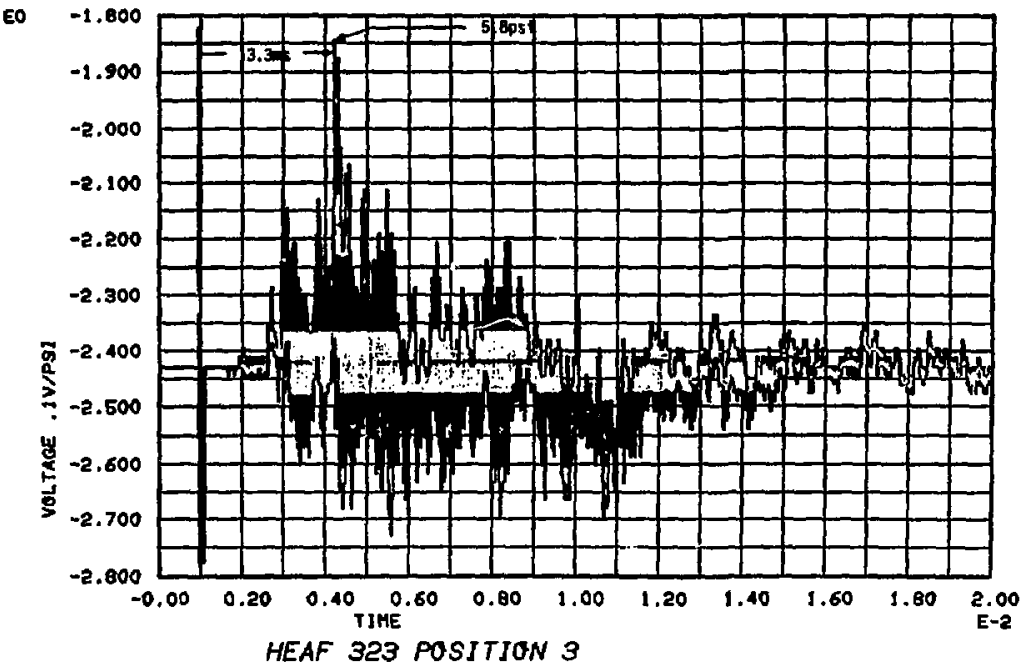



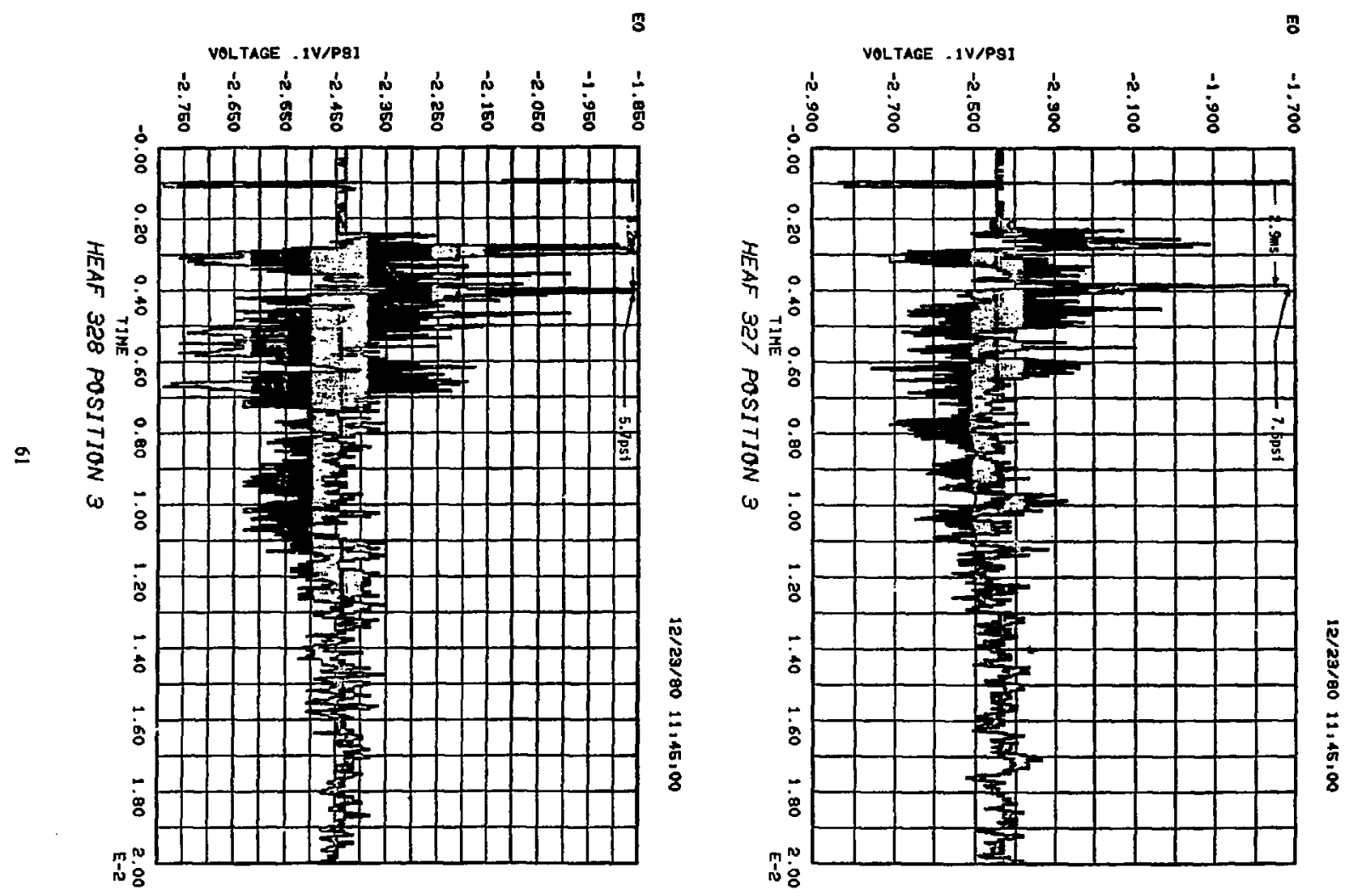


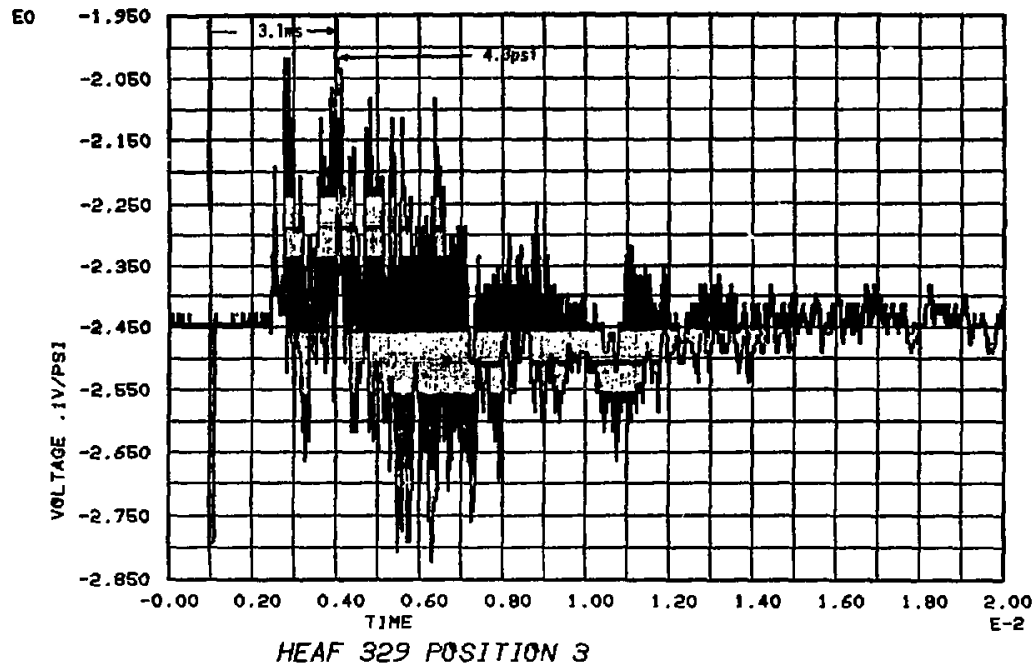

